\title{
MASTER
}

ORNL-5201

D. 654

\section{Properties of Carbonized and Converted Uranium-Loaded Weak-Acid Resins}

\author{
G. W. Weber \\ R. L. Beatty \\ V. J Tennery
}

1

$*$

OAK RIDGE NATIONAL LABORATORY

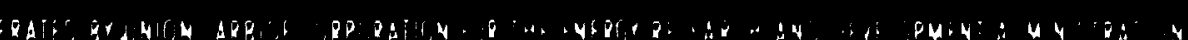




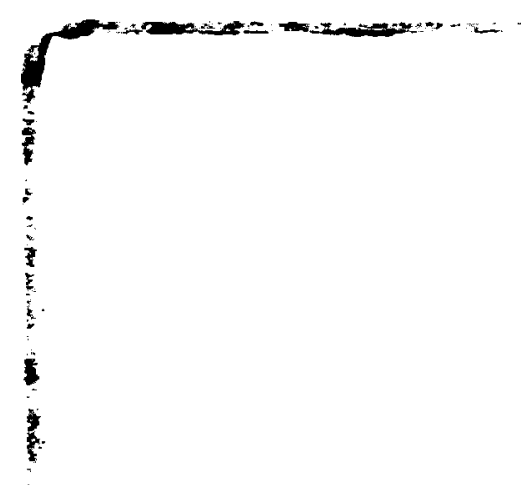

y

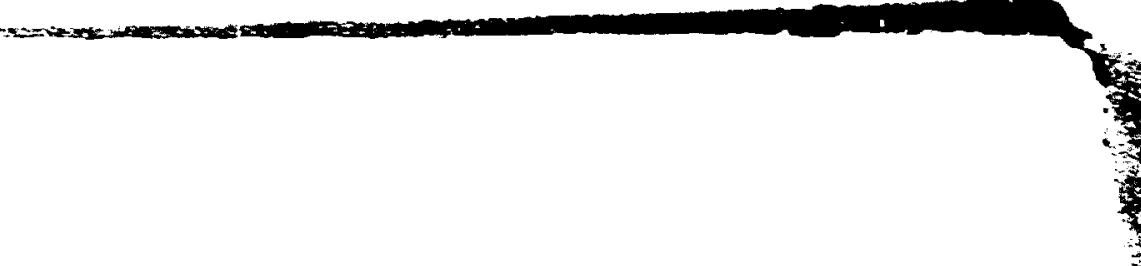

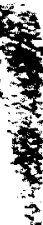

$\frac{1}{3}$

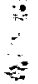

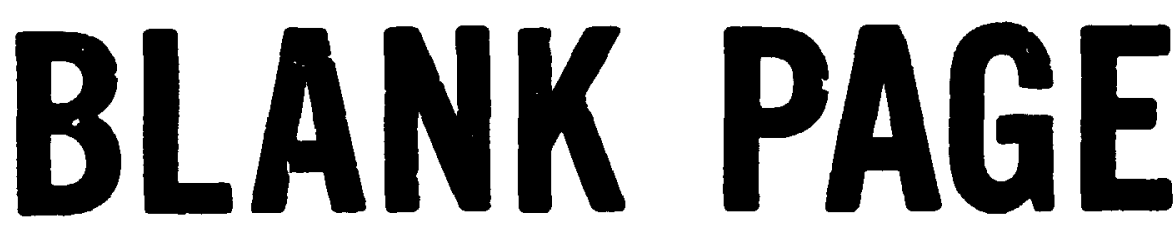

$x$
4
4

1

2

t

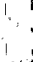


Printed in the Uriciei States of Americs Aratlable from Natwonai Technical informaticr. Service

US Deparment o' ronimerce 5285 Fort Royal Road. Sorin.jfues. Virginia 22161

Price Printed Copy \$\$.50. Nicrotiche $\$ 300$

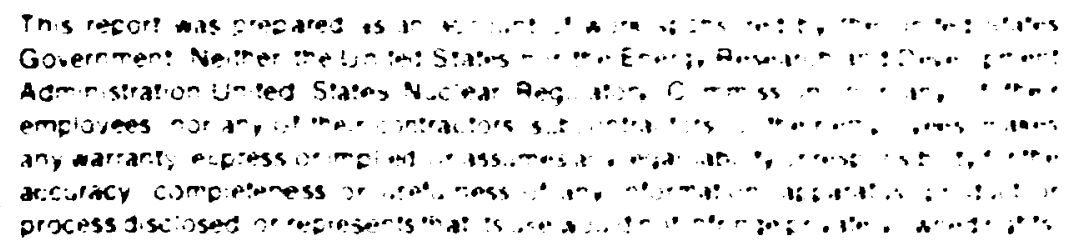


metals ano ceramas ouvarm

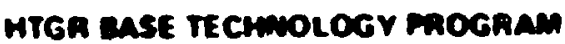

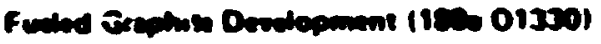

PaOreatics of cancomzeo ANo converteo

URANUSH.LOAOEO WEAK-ACDO AEsANS

G iv Weser

A L Bratly

V. J. Tennery

Dore Publighed: Fobruary 197

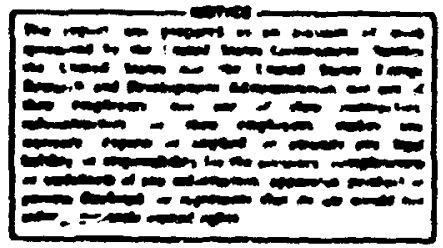

JAK ALOE MATIONML LABOMATONY

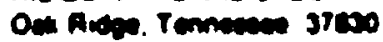

ovencen on

unow canerof conponarion

are

ENEAOV AESEAACH ANO OEVELOMEN: AOMMUSTAATION 


\section{contests}

Inetis?

Intrinaso (11.men

:

Prerimeries hivedurs

Meleist and t uinare

Thermang sutmettin indsw

Dheterntul thes mal indsess

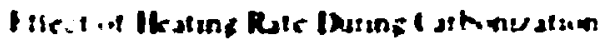

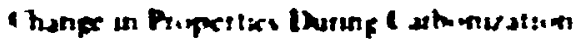

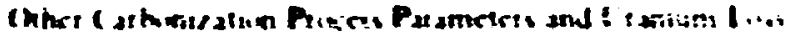

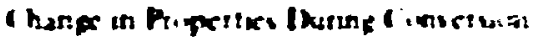

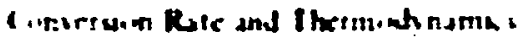

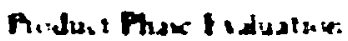

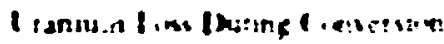

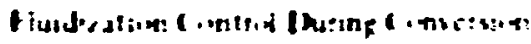

Vimingterh Rraitusts

Resuits

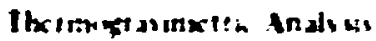

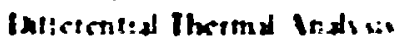

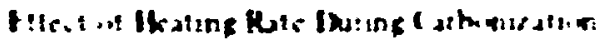

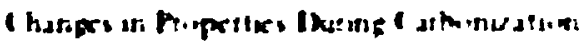

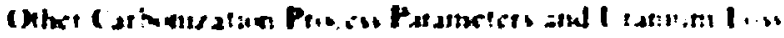

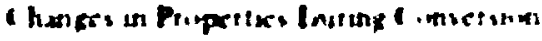

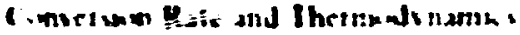

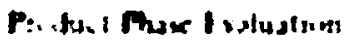

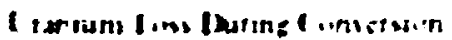

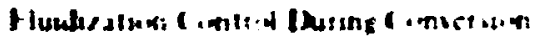

Menisill with the

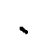

;

$\cdot$

(1)

handixtments

Mriereste: 


\title{
PROTERTIES OF CARSONIZED AND CONVERTED URANIUMUOADED WEAK-ACTD RESHS
}

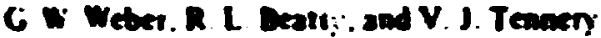

\begin{abstract}
AOTR CT

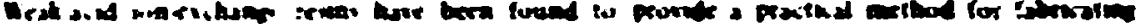

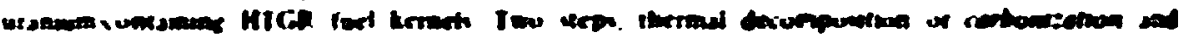

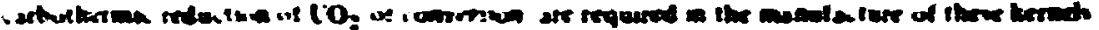

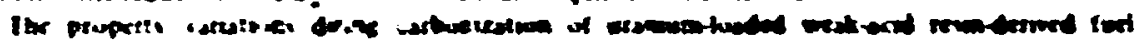

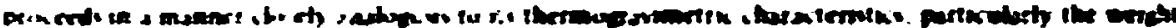

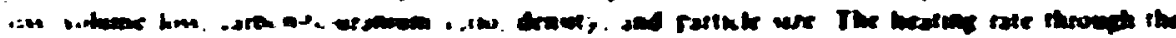

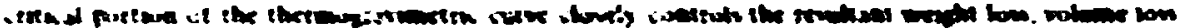

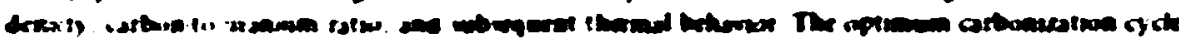

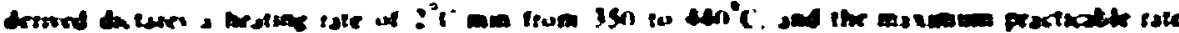

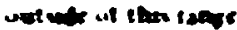

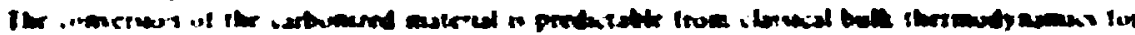

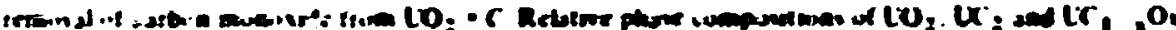

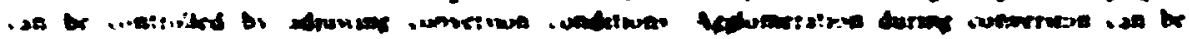

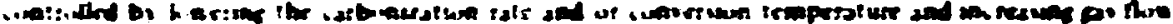

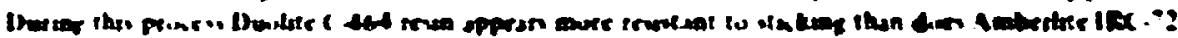

\section{Evropuction}

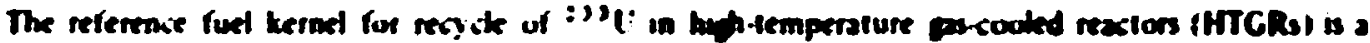

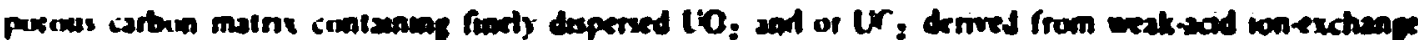

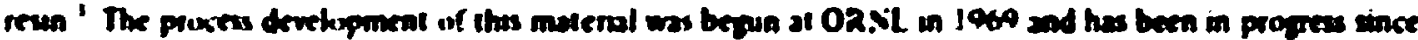

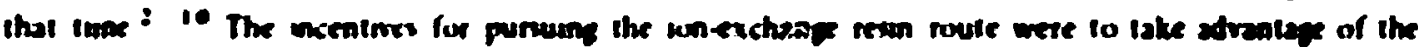

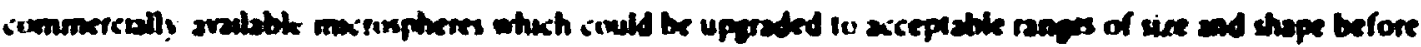

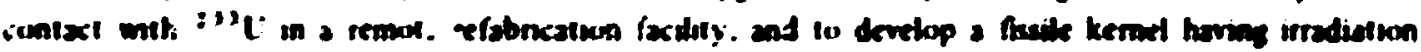

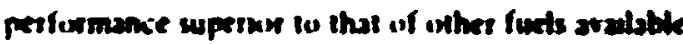

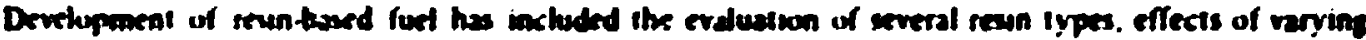

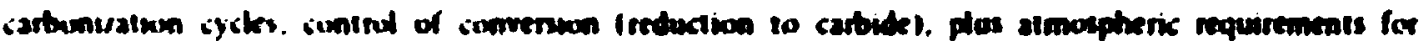

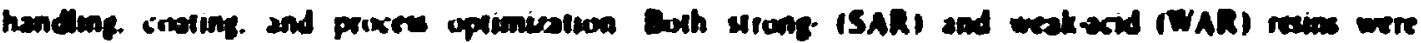

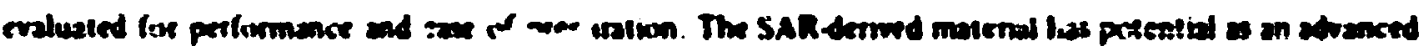

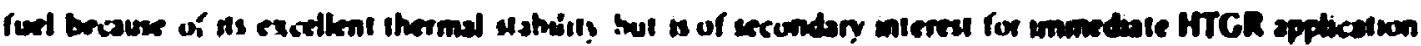

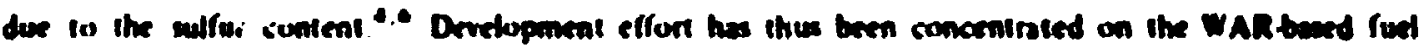

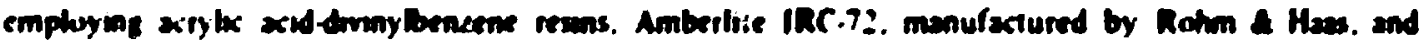

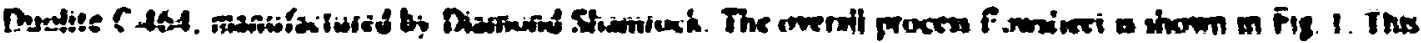

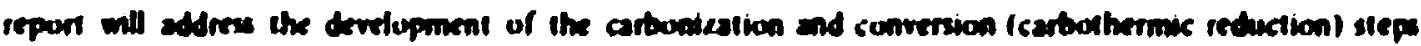
staning frum the dried uranmuntuaded resins

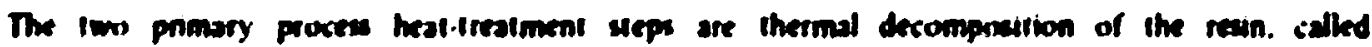

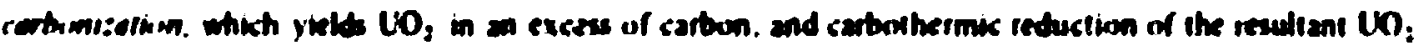

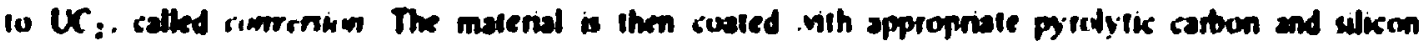
carbide layers designed for uptimum uradiation performance 3.9 .9 .10

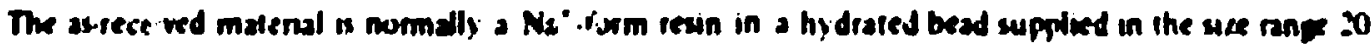

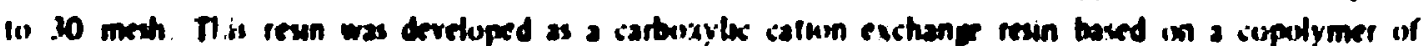


Weak-Acid Resin

-.:25se

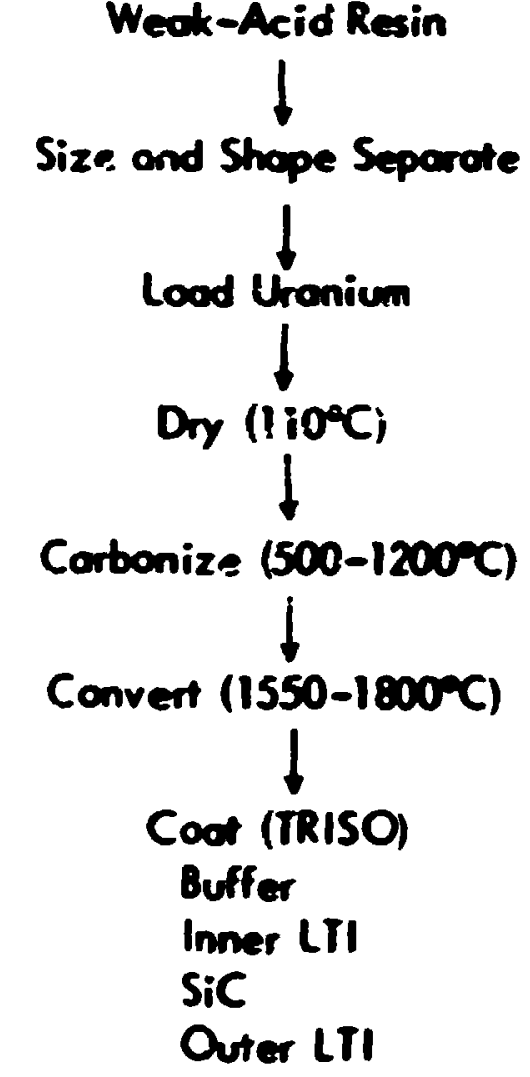

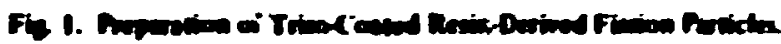

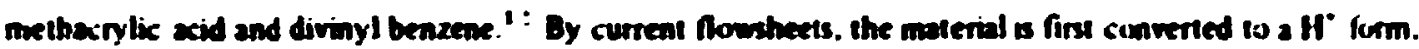
then loated with unowl wos by coatacting the reain with a uianyl nitrate solution which is acid deficient:

This material is then dried at $110^{\circ} \mathrm{C}$ to remove sone witer and yield rain $\bullet \mathrm{UO}_{2} \cdots$. The resulant

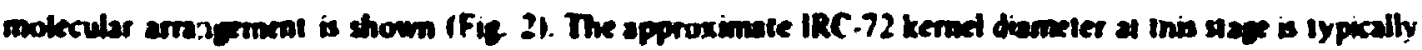
$5 S 0 \mathrm{~mm}$ wh a dexity of $1.6 \mathrm{~d} / \mathrm{cm}^{3}$. with 479 uranum at a loadiag of 63 mi particle.

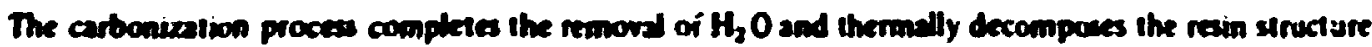

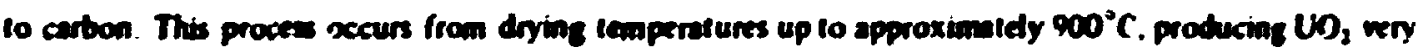

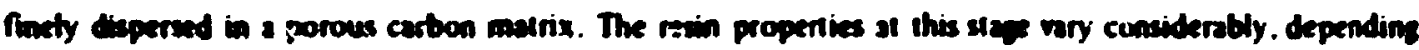

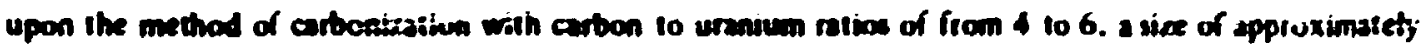
$375 \mathrm{men}$ with a censity of $2.4103 .7 \mathrm{~g} / \mathrm{cm}^{\prime}$ and weich petcent uranium of 6710757 .

The converion process involves corbothembic reduction of the UO, in the corbon matrix to UC, $\mathrm{O}_{1}$. and Ur, by the reatior

$$
U_{2}+3.86 C-C_{1.6}+2 c 0
$$

and

$$
U 0,+3 c+U c, 0, \ldots+12 \text {,ico }
$$


OPNL-DNG 74-2388R

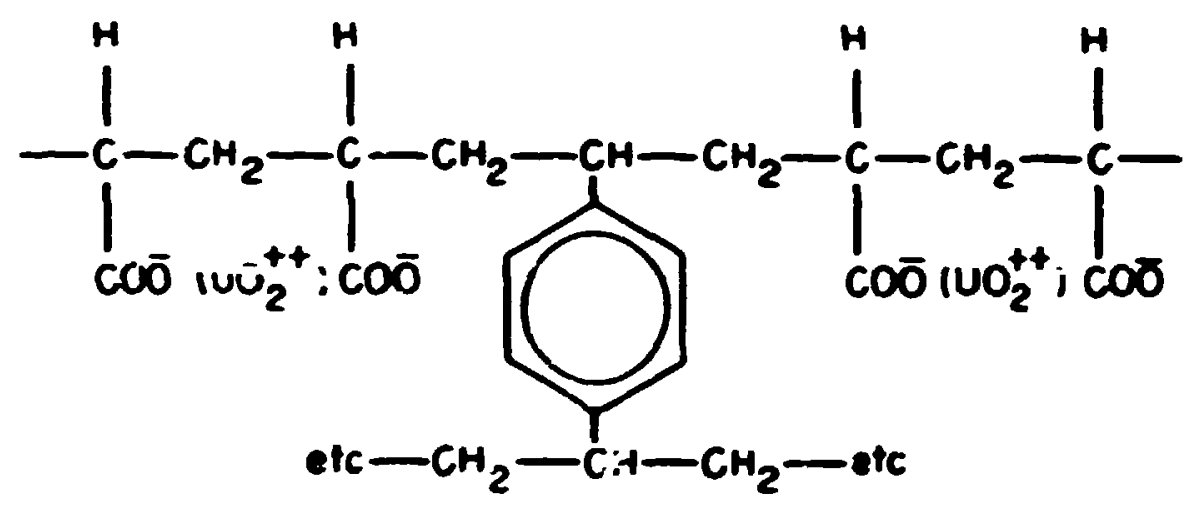

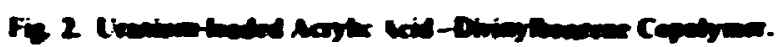

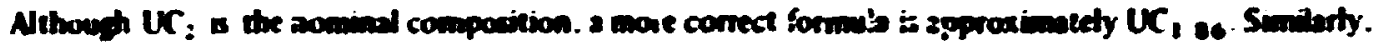

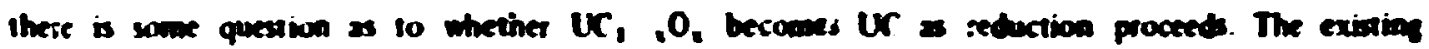

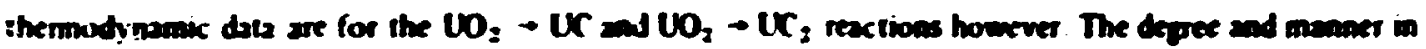
whach thex reactions are carried to conpletion at 1500 to 1800 C determace the retinive proportions of

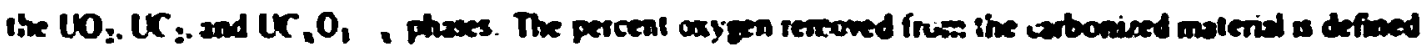

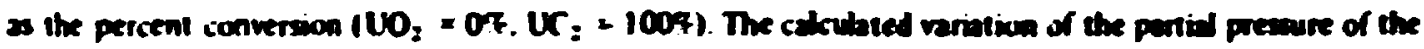

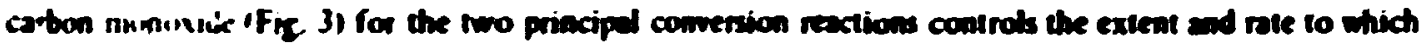
conversion is carried out." 2 Ths is inve becasse of the rey hinh surface ares present in the cartoonized

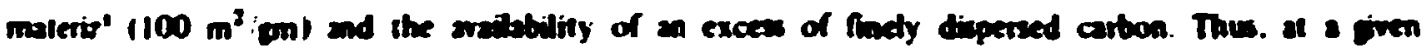

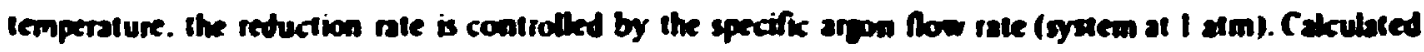

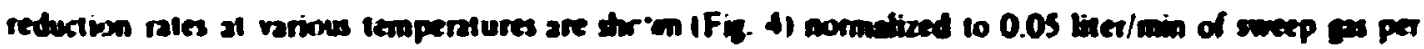
eram unvivem: the arpon flow rate is directly proportional so the reduction rate. Or course. selection of Anw rate is limited to a mave suisable for fluidization. Ementially complete reduction can be effected in a few minutes at $1800^{\circ} \mathrm{C}^{\circ}$. and controlled partid retucticn may conveniendly be bone in the $1600 \mathrm{n}$ to $1700^{\circ} \mathrm{C}$

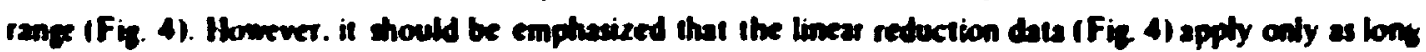
at the material has suftrient open porosiny fi.e. does ron sintat appreciably).

The final weight percent uremietm ranges from 72 to 867 . depenting upon the convenion proces. Find

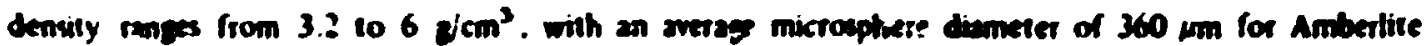
IRC.72.

The prepared fuet kernets ane then tren a bow dertaity pyrolytic carbon (ByC) buffer conting a

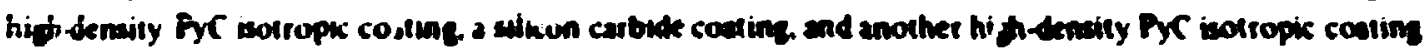
to yield a finiched TRLSO HTCR fmide particle.

The current work examines four apects of catbonuzation and conversion

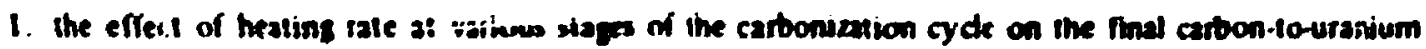
ratio, weight low. volume low. surface arta, and subuequent conversion beisarior:

2. the variation during the carbonization and conversion cydes of the density. Fore saxe diatribution. surface ares. wethi lose, volume loss. and carbontouranivm ratio:

3. The effect of different conversion temperatures and atmoepheres on the wroportions of $\mathrm{UO}_{2}, U \mathrm{C}_{2} \mathrm{O}_{1}$. and $U_{2}$ in the find materid: and 


$$
\text { I }
$$




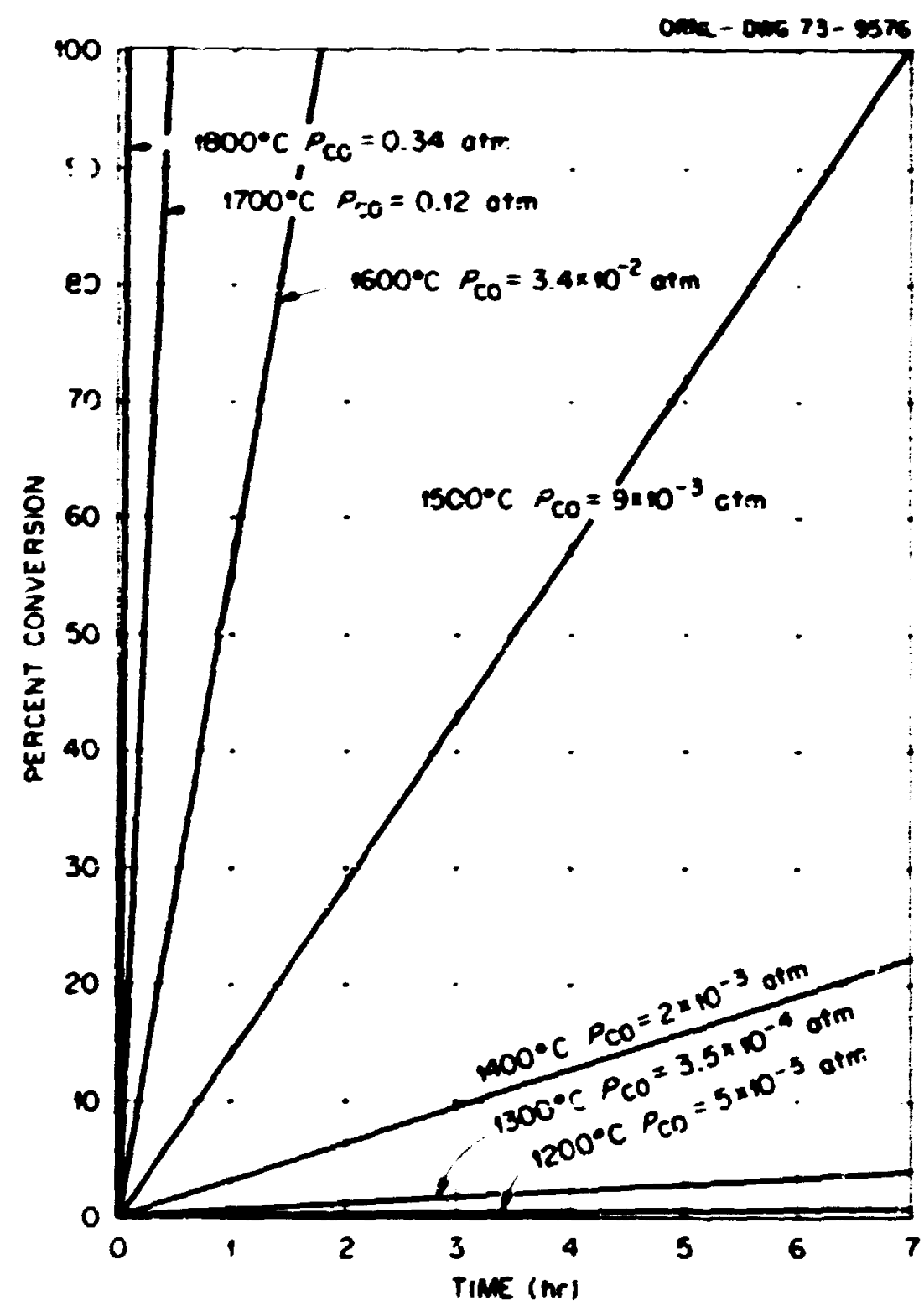

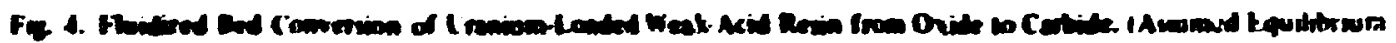

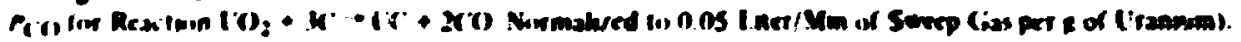

4 the cintelation between the abserved conversion nie and the bethovica predicted from clasucal bulk thermodynamics.

\section{EXPENMENTAL MOCEDURE}

\section{Materid and fincheres}

The cartunizalion. conversion and coating sleps were done in vertical gaphite resislance furnaces if if

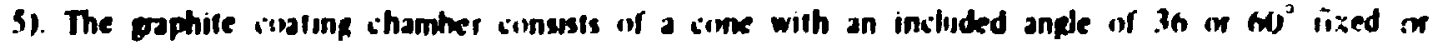
machined to a cylindrical graphile piece The mminal coating chamber diameter is ? $1 / 2$ in. with diameters of 3/4. 1. 1 3/8. and $13 / 4$ in. also available with appropriate adapters. Two methods of temperature 

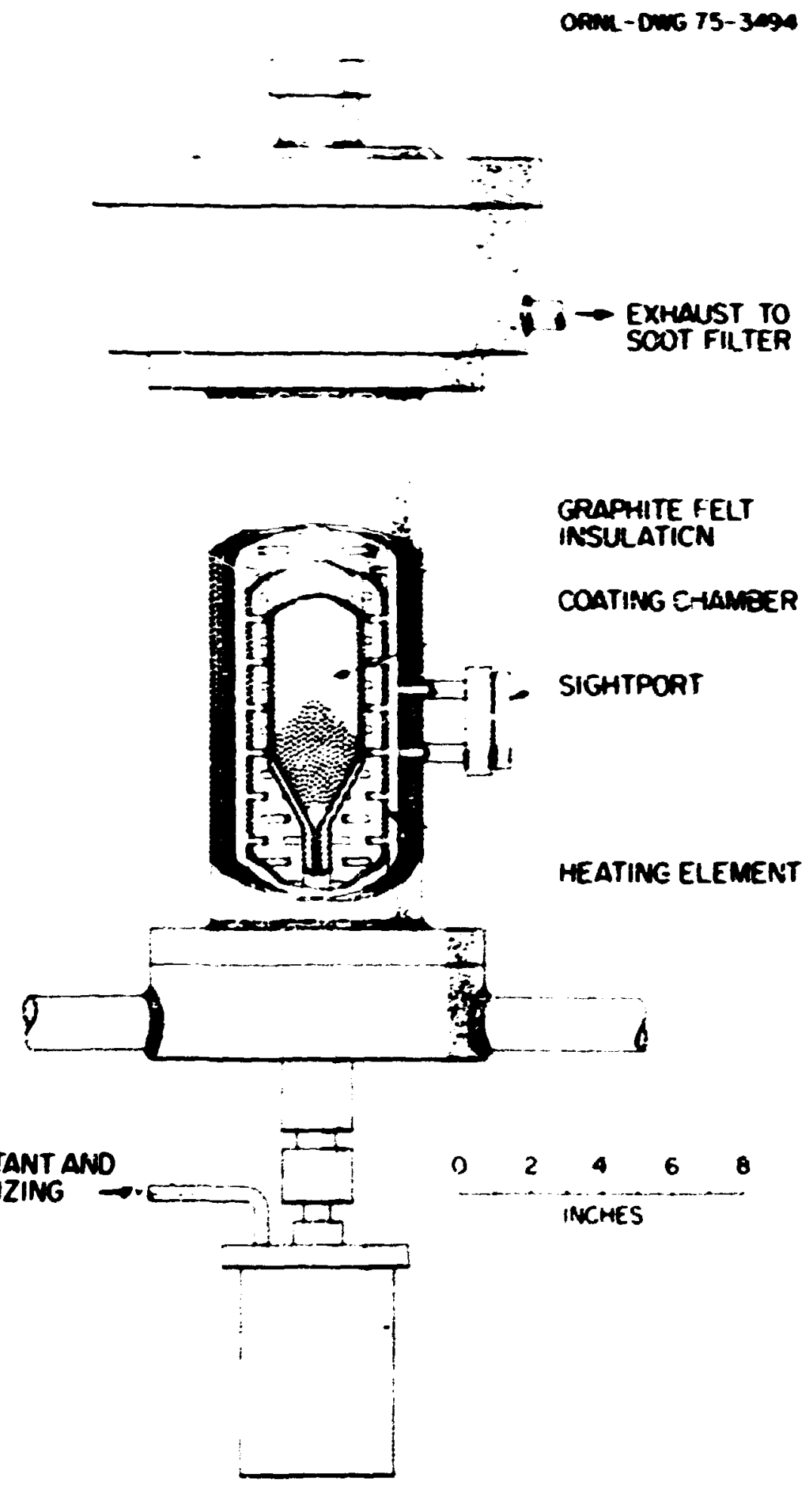

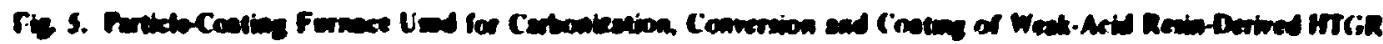
Font Pretioles. 
mraurement are andable. : sheathed ChrunselP Alund thermocouple is inserted directly into the bed through the fornace lup ior mesurement of temperatures from rown to approximatefy $700^{\circ} \mathrm{C}$. A sid port

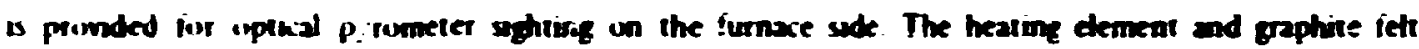

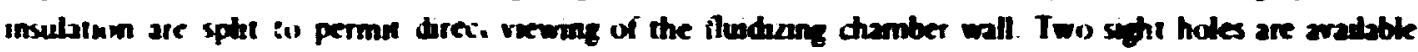
wih the howe: me stwated jest abure the conecylinder unction the lower sight purt wes used

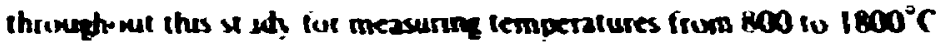

Reyuured lluwhing and rearant goses are supplied through alibrated flowmeters whe monitci and cuntrok hims ir ing ters of centumeters per minute to ters of liters per minute. Unles otherwise specified.

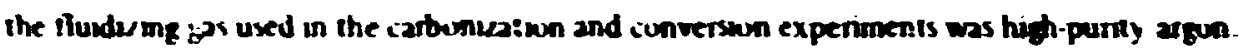

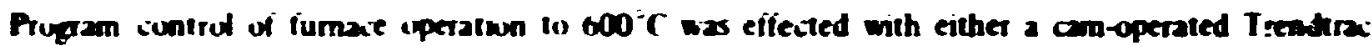

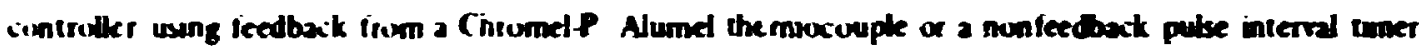
cuntroling the power supply. Furnace cuntiol above $600^{-} \mathrm{C}$ was acomplashed manually.

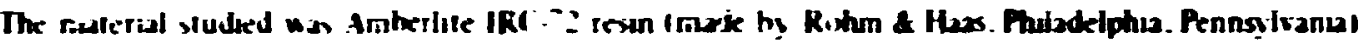

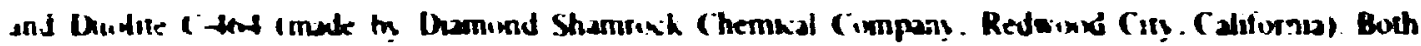

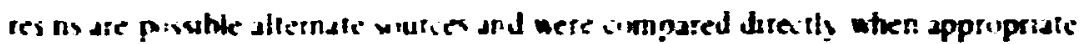

\section{Thermegrovimetric Andysis}

As thermal decrmpustim and water removal from the resin are aciompaned by substantiai weipt luss. tinermogavumetri andyses ITGAl identified iriticad arbonization temperatures. Diffetent heating rates were used in the TGA work io determane the effect of diferent caboniation rates on the decumpusstion of the resin. Dned resin was analy aed with a Mettler Recording Vacuum The. onoanatyzer ustng $150 \mathrm{mg}$ samples in a thwing argm atmosphere. Temperatures were measured with a platinum $\mathrm{s}$

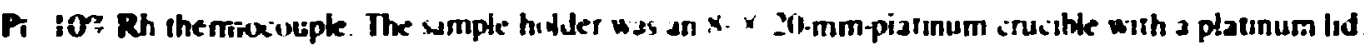

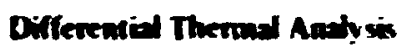

Since resun de. umposition is aciompanied by sigificant thermal effects. 3.4 differential therinal analysis IDTAI measurements were conducted to better define critical reactivi: steps. These meaurements were made with the Mettler thermoanalyzer sumultaneously with the TGA measurements. The reference material was $\mathrm{Al}_{2} \mathrm{O}_{3}$ powder with a sample weight equal to that of the dived resin sample. The sensitivity and time response of the DTA instrument were such that optimum DTA traces weic obtained only at a heating rate of $57 \mathrm{C}$ min

An experiment determined the species tha: evolved at different tempetatures. Fifty grams of resin were heated at $5^{c} \mathrm{C}$, min in a $\mathrm{I}-\mathrm{in}$. dism coating tube with a 2 liters $/ \mathrm{min}$ argon flow. The off $\mathrm{Z}^{\mathrm{s}}$ was collected at 150. 250. 355. 425.475 , and $600^{\circ} \mathrm{C}$ in a series of parallel sampling buttles by sequential bottle isolation at each stated resin temperature. The contents of these bottles were then analyred by gas chromatography. An in line water conled trap was installed to monitor evolution of condensables.

\section{Effect of Heation Rate Durins Cartonization}

The TGA and DTA results showed the special importance of the range from room temperature to $500^{\circ} \mathrm{C}$ as regards weight loss and thermal behavior in the carbonization cycle. To determine the effect of heating rate on critical process parameters. U toaded $25+30$ mesh Amberlite IRC -72 batches were heared at different rates from room temperature in $500^{\circ} \mathrm{C}$ followed by rapid heating to $1200^{\circ} \mathrm{C}$. Batches of $25.0 \mathrm{~g}$ were heated in 1 .in.diam tubes with a fuidising as flow of 3 liters $/ \mathrm{min}$ to $500^{\circ} \mathrm{C}$ and then 2 liters'min io $1200^{\circ} \mathrm{C}$. After heating at $1200^{\circ} \mathrm{C}$ for $5 \mathrm{~min}$. the samples were analysed for weigh loss. volume loss. and chemical compusition. 
To further define the region of importance in carbonization, similar experiments were done with Duolite C 464 resin. Material of $-30+35$ mesh in batch sizes of approximately $40 \mathrm{~g}$ was heated in a $1.3 / 8$ in. furmace tube. fi ating rate was planned to yicld various heating curves. Gas flow was regulated during the run at $9 \mathrm{liters} / \mathrm{min}$ frum room temperature $\$ 0100^{\circ} \mathrm{C} .8 \mathrm{liters} / \mathrm{min} 10200^{\circ} \mathrm{C}$ and $6 \mathrm{liters} / \mathrm{min}$ to $600^{\circ} \mathrm{C}$. The final temperature of $i 200^{\circ} \mathrm{C}$ was held for $30 \mathrm{~min}$. Wright loss. volume loss. and chemical composition were determined for the carbonized material.

\section{Cusere in Properties During Corbonization}

The physical property variations with temperature during a typical carhonization run wrere determined with ters on Drolite and Amberlite. Batches of $70 \mathrm{E}$ vere heated in a $13 / 8$-in. diam tube at $2^{\circ} \mathrm{C} / \mathrm{min}$ to setected temperatures under $500^{\circ} \mathrm{C}$ and at $20^{\circ} \mathrm{C} / \mathrm{min}$ to temperatures over $500^{\circ} \mathrm{C}$ and then ccoled rapidly to room temperature. Fluidizing ges flows were $15 \mathrm{liters} / \mathrm{min}$ from room temperature to $185^{\circ} \mathrm{C} .9$ liters/min from 185 to $950^{\circ} \mathrm{C}, 7$ liters/min from 950 to $122.0^{\circ} \mathrm{C}$, and 4 liters/min from 1200 to $1625^{\circ} \mathrm{C}$. Weight loss. rolume icus. tap density, mercury density, mercury porosinetry. BET surface area. carbon-to-uranium ratio. and particle size were determined. Tap density a discrissed in this report is the weight of particles divided by the volume occupied in a gaduate of appropriate size. assuming perfect packing: tap density/0.62 is equal to the true pens. As temperature increases. the finely distributed $\mathrm{UO}_{2}$ adomerates into coherently diffracting rezinns of increasing particie size. To investigate this behavior. samples were heated to different temperatures in the carbonization cycle. rapidly cooled to roum temperature, and examined by $x$-ray diffraction. The material was gound in a Diamond Phattner mortar to - 325 mesh and sealed in 0.005-in. glass capillaries with Apiezon and houschold cement. The sample was examined with an 11.54-cm-dian Debye-Scherre: camera wit:' monochromatic CuK $\times$ rays for apf:oximately 46 hr.

\section{Other Carbonization Proces Pananters and Uranium Loss}

Uranium loss during carbonization was determined with an improvised onllecting scheme. Because the uravium-centaining species releaset during carbonization may be carried in an aerosol. collection is difficult. The collection method involved packing the fumace lid and initial off fas flow path with gauze. After a run, the gauze and a newly constructed and therefore previously uncontaminated furrace lid were counted with an alpha survey meter. The tars and residue in the gauze were to function as a collection medium for the aerosols given off during carbonization: but how successful this was is not klown. A typical carbonization cycle was run with $235 \mathrm{~g}$ of material at $2^{\circ} \mathrm{C} /$ inin $101202^{\circ} \mathrm{C}$.

A second cycle was run in which a 150.8 batch was heated from room temperature to $1200^{\circ} \mathrm{C}$ at approximately $170^{\circ} \mathrm{C} / \mathrm{min}$. The residue collected on the :op portions of the furnace was absorbed on tissues and gauze and sprayed with acetone to break down the tars for alpha counting. The tissues and gauze were subsequently reduced to ash and the uranium content determined.

Nternate carbonization atmospheres wers investigated in an attempt to increase the resin coking yicld (corbon-lo-uranium ratio). As this process of thermally decomposing the resin is similar to pyrulysis reactions in other hydrocarbons. alternative approaches sugzested by such work were explored. Bacon' 3 has shown that sibstituting hydrogen chloride for nitrogen signifi:antly decreased the weight loss and widened the temperature range of reaction for the pyrolysis of rayon. Similarly. substituting oxygen for argon up to the critical reaction temperature decreased the weight loss observed in pyrolysis of Villwyte rayon.

To investigate atmospheric effects on the HTGR resin princess, air was sibstituted for aigon to $270^{\circ} \mathrm{C}$. the point of the first significant reaction. is a $1200^{\circ} \mathrm{C}$ carbonisation process for a $40-8$ batch of Amberite IRC:.72 risin heated at $2^{\circ} \mathrm{C} / \mathrm{min}$. (arhom and uranium conlent were determined for the resultant material. 
Similarly, the effect of hydrogen chloride was investigated by installing 3 bubblet with concentrated hydrogen chloride in the fluidizing (argon) line. Hydrogen chloride wes introduced to $500^{\circ} \mathrm{C}$ in nims otherwise identical with those previousty described.

Exposure experiments on these materials were done abo to determine what effect the different procedures might have on the reactivity of the carbonized naterial. One-gram botches of the carbonized material were exposed to air and the resultant weight gain recorded.

\section{Change in Properties Duriag Comersion}

To ascertain the property variation during the conversion process. a series of $70_{8}$ batches of Amertite - Dri Duolite was carbunized in a $13 / 8$-in. diam tube at $2^{\circ} \mathrm{C} / \mathrm{min}$ to $500^{\circ} \mathrm{C}, 20^{\circ} \mathrm{C} / \mathrm{min}$ from 500 to $1200^{\circ} \mathrm{C}$, and $100^{\circ} \mathrm{C} / \mathrm{min}$ from $1200101625^{\circ} \mathrm{C}$. The fluidizing gas fows were 15 liters $/ \mathrm{min}$ from rocm temperature to $185^{\circ} \mathrm{C} .9 \mathrm{liters} / \mathrm{min}$ from $18510950^{\circ} \mathrm{C} .7 \mathrm{liters} / \mathrm{min}$ from 950 to $1200^{\circ} \mathrm{C}$, and 4 iners/min from 1200 to $1625^{\circ} \mathrm{C}$. The percent weight loss. percent volume loss. particte size. tap density, mercury density, and carbon-to-uraniam ratios were determined as a function of time at conversion temperature. Times from 0 min to 1.67 of the time calculated for complete conversion of the $\mathrm{UO}_{2}$ to $\mathrm{UC}_{2}$ were used.

The pore size distribution produced in partinlly conierted weak-acid resin Duolite and Amberlite fuets was gudied by carbunizing and converting batches containing $12 \mathrm{C} \&$ of uranium at $1525^{\circ} \mathrm{C}$ to 34 and $32 \%$ conversion respectivety. The pore size distribution of this material was then determined by measuring the mercury density as a function of pressire. The diameter of the pores penetrated by mercury was determines from the formula:

$$
\operatorname{diam}(\mu \mathrm{m})=\frac{175}{\operatorname{psia}\left(\mathrm{H}_{\mathrm{g}}\right)}
$$

\section{Connersion Rate and Thenmodynumics}

Experiments were also conducted to directly compare observed with predicted conversion ievels for varimus specific gas nows. temperatures, and balch sizes. Thirly-five experiments were conducted at gas flows from 0.295 io 7.37 liters of argon/gram of uranium at temperatures from 1500 to $1690^{\circ} \mathrm{C}$ and $\mathrm{x}$ conversion levels from 15 to 93\%. Batch sizes varied from 28 to 486 in furnace tubes from 3.5 to $10.8 \mathrm{~cm}$ in diameter. Five of the experiments wer: conducted with Duolite $\mathrm{C} 464$ and the other 30 with Amberlite IRC-72. Additionally, particle size was varied for different batch sizes and gas flows to ascertain the effect on conversion level for a series of six different runs $211575^{\circ} \mathrm{C}$ in a $4.44-\mathrm{cm}$-diam tube.

Tn ascertain the possible temperalure error between measured and actual temperature during a conversion run. parallel measurements were carried out with a platin: in us Ph- $10 \%$ Rh thermocouple in the bed and an optical pyrometer sighting on the furnace tube wall (Fig. S). The bed thermocouple and top sighting port were located $7.3 \mathrm{~cm}$ above the tube orifice. The normal measuring sight port used for experimental control is $3.5 \mathrm{~cm}$ above the tube orifice. The particle bed extended to approximately $8.6 \mathrm{~cm}$.

To investigate the effect of fluidization conditions, the platinum is Ph-10\% Rh bed thermocouple and control sight port were simultaneously monitored at approximately constant power level as fuidization conditions were varied.

\section{Product Phase Eviluation}

Phase identification stucies were conducted by carbonizing material at $2^{\circ} \mathrm{C} / \mathrm{min} 10600^{\circ} \mathrm{C}$ and then heating to the conversion temperature. Conversion was done at 1505 and $1625^{\circ} \mathrm{C}$ in argon: at $1525^{\circ} \mathrm{C}$ in 
argon with $4 \%$ hydrogen addition and at $1628^{\circ} \mathrm{C}$ in argon with carbon monoxide addition equal to 0.75 of the equitibrium partial pressure of abon monoxide at the conversion temperature. To accomplish bis iast addition. carbon moroxide wes added to the fluidizing. After conversion. this matrial was analyzed for phase content by the $x$-ray power technique described previousdy of the gas in proportion to 1.75 partial pressure at $1628^{\circ} \mathrm{C}$.

\section{Unerien Las Dring Cemresion}

To identify the anount of uranium lost during the conversion process. a water-covked aluminum fumace probe wes fabricated to condense and yantitatively collec! any cranium released during the process. This probe extended downerd to a point imunediately above the hot zone of the fumace (Fig-5) to ensure complete condensation and collection of uranium-bearing vapors. A run with 150 \& of 3 busiced. screened, shapeseparation rejected kemels was pade to $73 \%$ conversion at temperat1:s:s from 1650 to $1800^{\circ} \mathrm{C}$. After the comversion the fumace probe was counted with an alpha survey meter. A $5 \%$ solution of nitric acid was used to remove the collected material from the probe for temical analysis.

A similar run was made with $150 \mathrm{~g}$ of shape-sepayaled. sereened arbomised $\left(2^{\circ} \mathrm{C}\right.$ min) material il approximately $98 \%$ conversion at $1775^{\circ} \mathrm{C}$. Throsghout this run, the lurnare prote was subjeiled io direct particle impingement so that pasticles aitually stuck to the probe. Luse partikles were remened and the probe counted with an alpha survey meter.

\section{rTuidiation Control Durias Conversion}

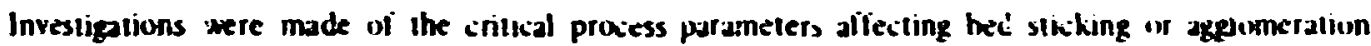
during conversion of weak-acid resin-derived fuel. A single lot of driad Amberlike IRC-72 resin was arbonized at $2^{\circ} \mathrm{C}$ imin from 200 io $500^{\circ} \mathrm{C}$ and then at $20^{\circ} \mathrm{C}$ min $: 01200^{\circ} \mathrm{C}$ in two hatches of 1000 and $730 \mathrm{~g}$. The material was then converted in a $+.4 \mathrm{~cm}$-diam tuhe at $1525^{\circ} \mathrm{C}$ in $80 \mathrm{~g}$ batihes at argun nows from +.5 to 9.0 lisersimin. Finsl ikernel diameter was $450 \mu \mathrm{m}$ with a density of approxima tely $3.1 \mathrm{~g}^{\mathrm{im}} \mathrm{cm}^{3}$.

Since the onset of bed stikking is not easily specified. a subjective classitication was established. A Ma-ineheli: gage, installed to measure injector bak-pressure. was used for the arbitrary classification. The bed was ategurized as free if Magnehelic pressure variation was less than $5 \mathrm{sm}$ of water. Showing "slight sluggng" if pressure :ycling was $12.5 \mathrm{~cm}$ or less. "heavy slugging" if the iycling was grazter than $12.5 \mathrm{~cm}$. and "sticking" if the gage went full scale $1125 \mathrm{~cm}$ ) twice or failed to racover after the first exiursion. Sligging is a visually observahle phenumena in which the material settles and is than biown in a mass up into the furnace tube. The time at which this occured wa recorded, and assuming $a$ constant conversion raic with time, the approxinate conversion level at which this behavior cciurred was deterinined. The gas now for each run was divided by the total bed particle atea (o establish a gas fux.

To evaluate the relative agglomeration behavior of the two candidate resins. a comparisin run was mide in a 1 -in. tube at 2.5 liters/min argon with $50 \mathrm{~g}$ balches of dried resin. A heating rate of $8^{\circ} \mathrm{C} / \mathrm{min}$ from 100 to $500^{\circ} \mathrm{C}$ and a conversion time of $30 \mathrm{~min}$ at $1700^{\circ} \mathrm{C}$ were used. The Duolite batch was very louse throughout while the Amberlite nearly stuck at $12 \mathrm{~min}$ inio the run and barely remained fluidized for the remainder of the run.

Analagous runs were made "'ith $80 \mathrm{~g}$ of material in a $13 / 8$ ilt. lube at $2.5 \mathrm{itters} / \mathrm{min}$. The Amberlite run was aborted after $11 \mathrm{~min}$ at $1700^{\circ} \mathrm{C}$ due 10 sticking and slugging of the balch. The Duslite run was completed without incident.

Larger comparison nuns were made with approximately 250 z of material in a $21 / 2$ in. tube at 5.0 litersimin. Conversion was done at $1625^{\circ} \mathrm{C}$ for $33 \mathrm{~min}$. The Duolitc resin was slightly sluggish the last $\mathrm{o}$ min of the nun. However, the Amberlite became sluggisl: 3 min into the run and began sticking 5 min into the iun. 


\section{Alonospmeric Reactiviry}

To compare sarbuniced partikile-simosphere reactivities as a fumition of heat treatment. lots irom a

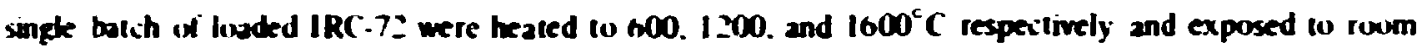

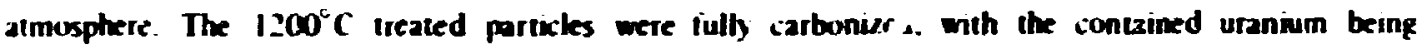
essentially $1 \mathrm{CO}_{2}$. The $1600^{\circ} \mathrm{C}$ trealed partictes were nkminally $1 \mathrm{O}_{2}+\mathrm{C}$ with about $15^{\circ} \mathrm{r}$ of the uxy gen remuced. Dupluate It samplex. une eath in an unapped botte initially filted with agon and the cher poured mto an upen besker. wer: expused to compare reacition rates.

In a further experiment. wighi gains were recorded as funitwns of time for uranium-loaded IRC.72 ireated at 500. 1200. and $1800^{\circ} \mathrm{C}$ : these samples were respectively: carbusized through the critisal heating rate ranze : fulby carbunize J: and iully reduced to dicartide.

\section{RESULTS}

\section{Timenoparimetric Amolyss}

The thermugravimetrik anatyses (TGA) shuwed Ainberlite IRC-72 marerial experiencing a gadual weight kass $10270^{\circ} \mathrm{C}$ for the $2^{\circ} \mathrm{C} \cdot \mathrm{min}$ heating rate (Fig 6). The $2^{\circ} \mathrm{C}$ min rate then shuws a barger weight

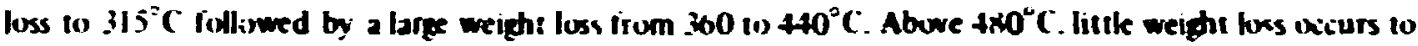
$1000^{\circ} \mathrm{C}$. Increasing the heating rate $1106^{\circ} \mathrm{C}$ min causes an apparent detas in the first luss lo abuut $215^{\circ} \mathrm{C}$ which continues to approxitsately $360^{\circ} \mathrm{C}$. The larg meigit loss at $6^{\circ} \mathrm{C}$ min ociurs from 395 io $485^{\circ} \mathrm{C}$ followed apain by littk kuss to $1000 \mathrm{C}$. This shift of weight loss to higher kemperatures with increasine heating rate may be attributed to lag in the response of the measuring apparatus. It is also apparent from the final weights that faster he. ing rates froduce more weigh: luss.

The Dustite C -404 resin shuwed essentially no weighr ioss $10210^{\circ} \mathrm{C}$. after which a gradual loss occurred fior all heating rates. Faster weight losses occurred with lower heating rate 10 about $315^{\circ} \mathrm{C}$ abure which weight luss acielerated. The largest weyt loss axcurred for the $2^{\circ} \mathrm{C}$ min heating rate from $37510450^{\circ} \mathrm{C}$. for the $6^{\circ} \mathrm{C} / \mathrm{min}$ heating rate from 300 to $480^{\circ} \mathrm{C}$. and for the $10^{\circ} \mathrm{C} / \mathrm{min}$ heating rate from $40510500^{\circ} \mathrm{C}$. Abuve these maximum temperatures littie additional weight loss occurs $101000^{\circ} \mathrm{C}$. It is apparent that. for a

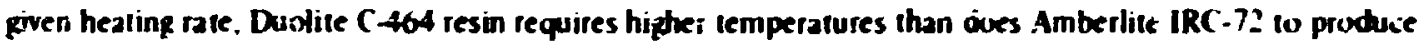
equivalent resin breakdown. That most weight loss occurs in the one narrow range from about 350 to $450^{\circ} \mathrm{C}$ is apparent from all of the TCA results obtained.

\section{Differentid Thernel Anatysis}

The differential thermal analysis for the Duolite C $\mathbf{4 6 4}$ and Amberlite IRC-72 shows three broad enditherms for toth resins (fig. 7). The Amberlice shows negotive peaks at 160-220. 33C. and $490^{3} \mathrm{C}$. Comparison of these peaks with the $6^{\circ} \mathrm{C} / \mathrm{min}$ TGA results shows that the first broad peak corresponds closely with the initial gadual weight los. The second large endotherm from 28$)^{\circ} \mathrm{C}$ io a peak at $330^{\circ} \mathrm{C}$ matches very closely the accelerating w.ight loss shown on the TGA curve. The largest endotherm heginning at $415^{\circ} \mathrm{C}$ and peaking at $495^{\circ} \mathrm{C}$ nay correspond as well to the observed weight loss curve. The relative DTA peak sires likewise are in at sordance with their relative weight losses. These DTA results correspond in peak temperatures to the re.ults of Pollock and Silverman" if endotherms are tabulated. The two apparent excutherms at 290 and 420 : may be caused by a shift in the base line since exothermic hehavior is not expecied in a destruclive distillation process. The uccurrence above $500^{\circ} \mathrm{C}$ of a steadily decreasing exotherm may possibly be due to evolution of hydrogen. 


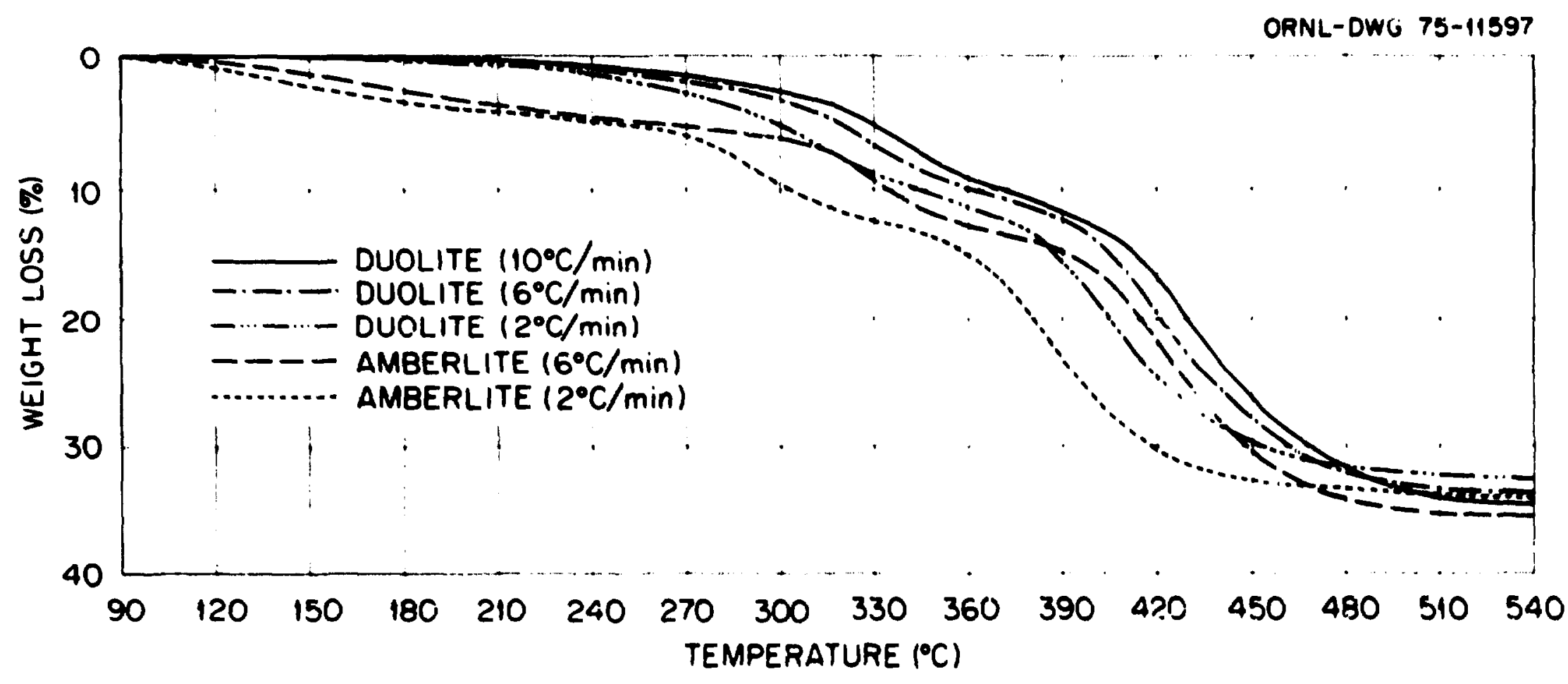

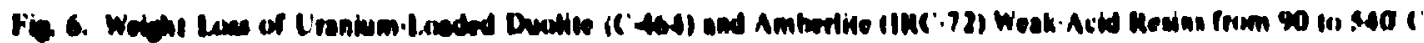

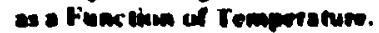




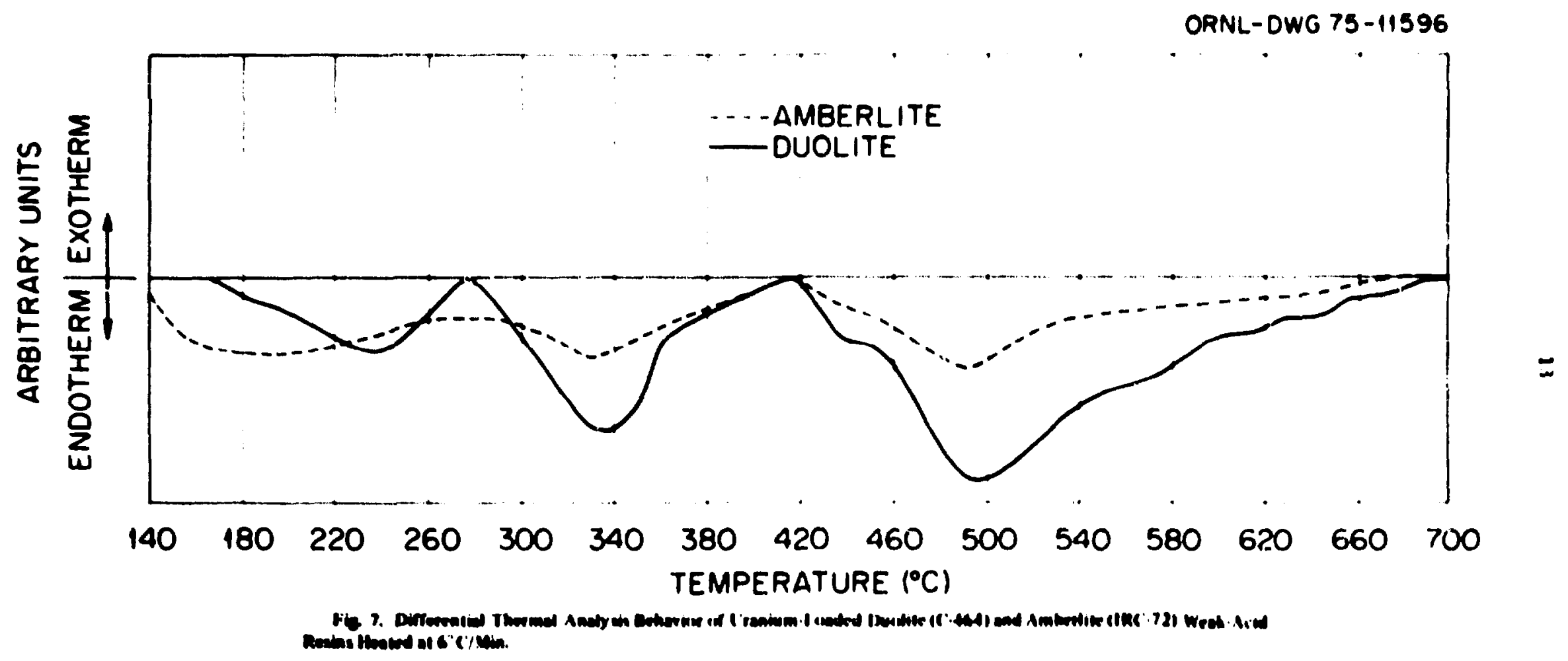




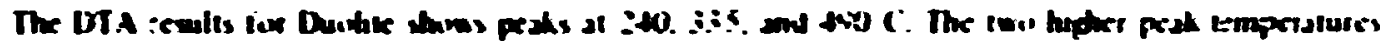

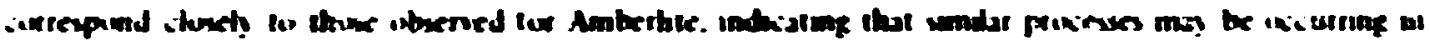

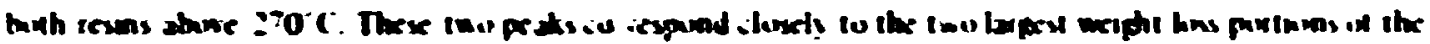

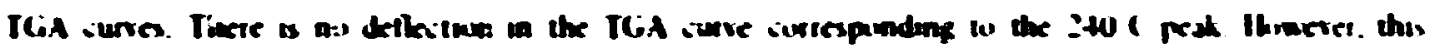

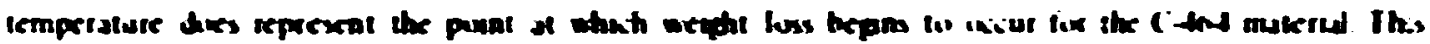

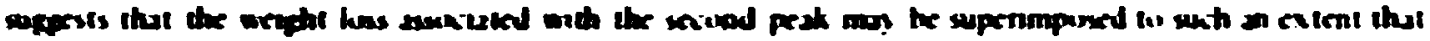

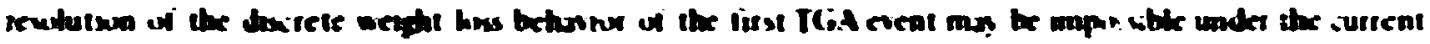

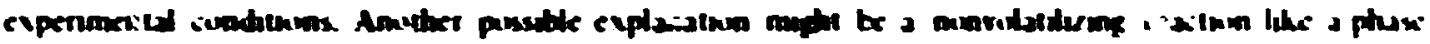

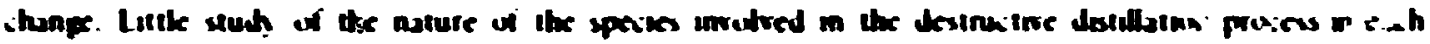

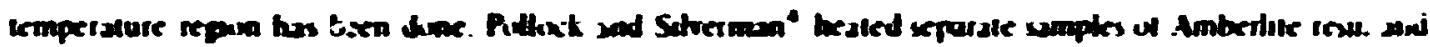

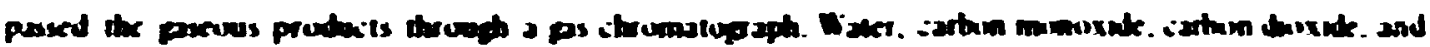

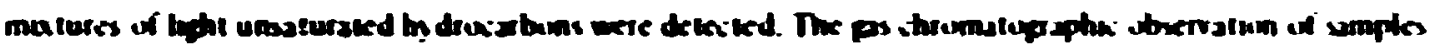

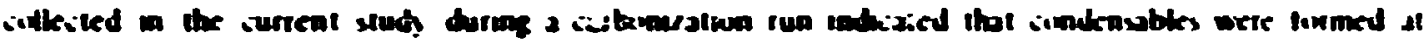

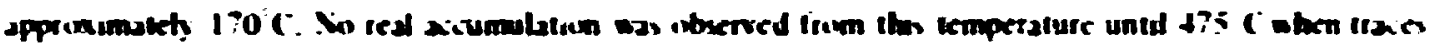

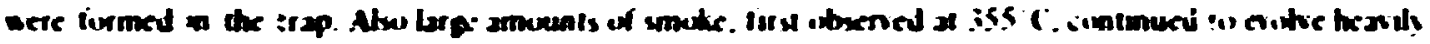

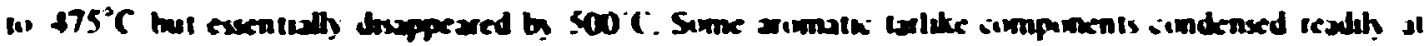

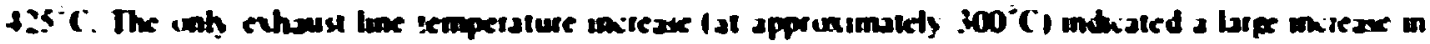

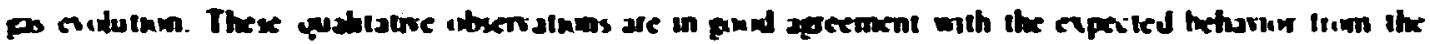

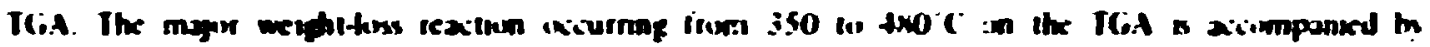

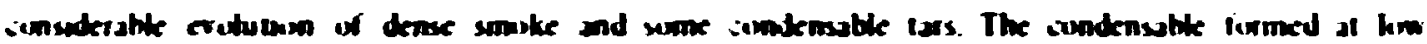

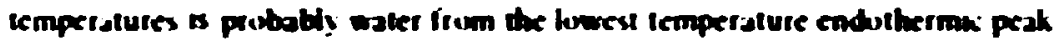

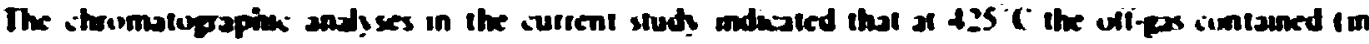

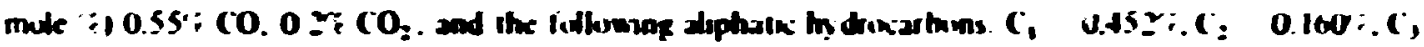

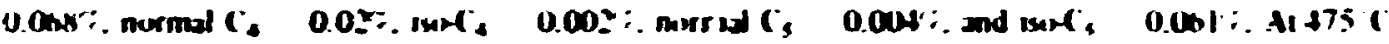

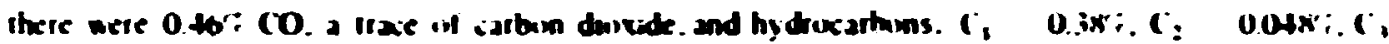

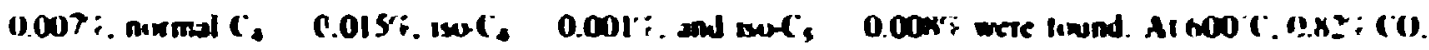

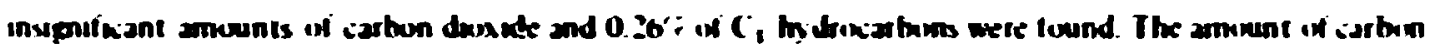

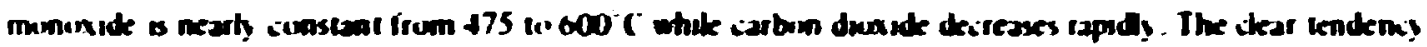

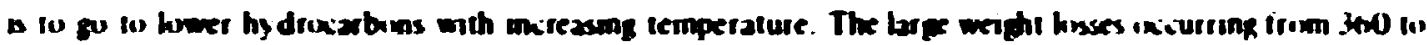

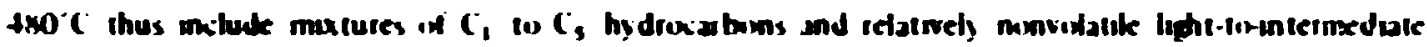

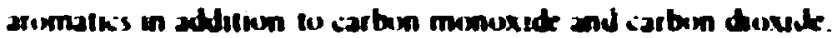

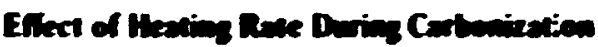

Since bare amounts of volates are evulved during the resm arbonuation. an early need was in"

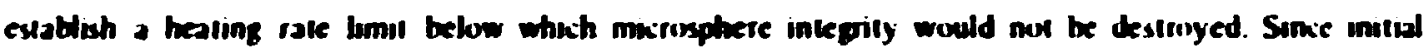

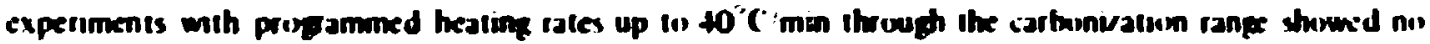

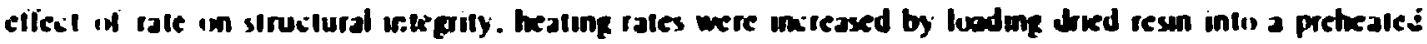
furnace.

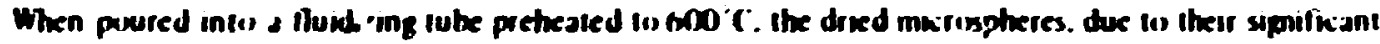
heal apaily. were healed theouph the entire range from romm temperature in 1300 "C al a rate of 290 in

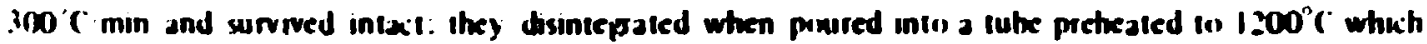

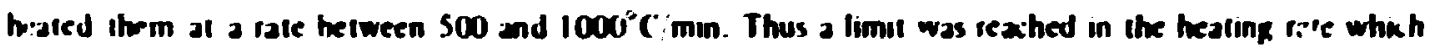

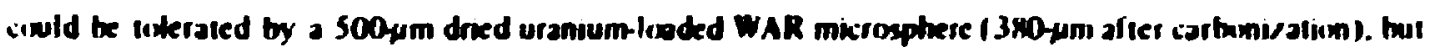
this limit was so hid that carefully proganmed heating was uneciesary for retaning suruitural untepaity. However. the amount of retained cabron (resin cuking yield) was sensitse io the heating tale through a limited iritkal iemperature range. 


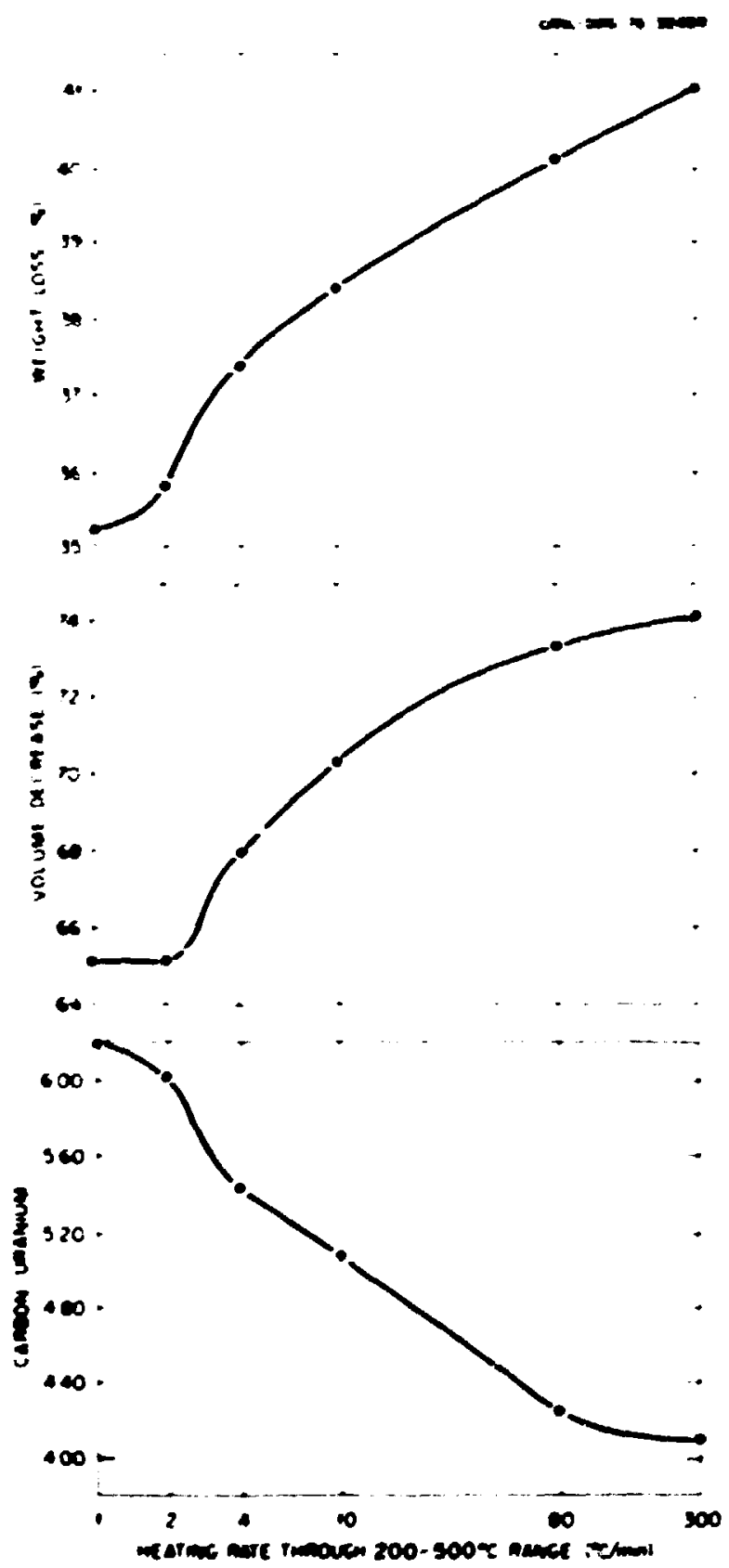

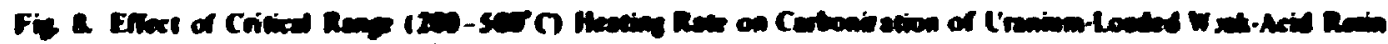

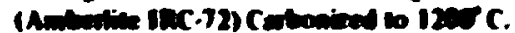

The effect of the healing rate on Amberlite IRC.72 irom $20010500^{\circ} \mathrm{C}$ (fig 8 ) shows a stose correspondence beiween weight and volume loss" and the logorithen of the teating rate. Chemacal arialysis of l'e carbon and uranium indicaled a similar strung aependence of the carbon-to-uranium ratic on the logarithm of the heating rate throwgh the cinikal region (fig 8). The neminal amcunt of excess carbon

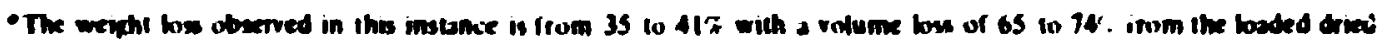
resin. 


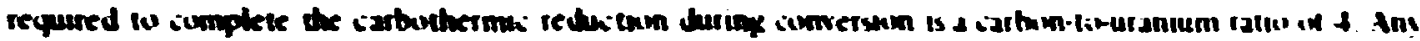

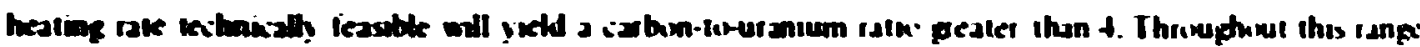

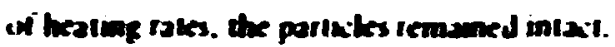

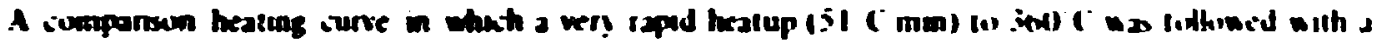

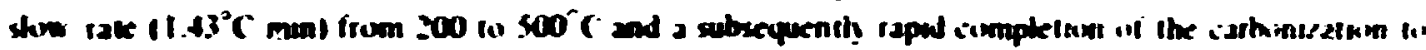

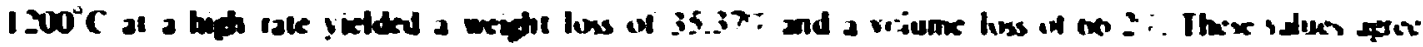

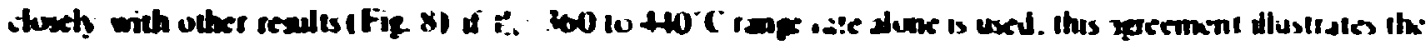

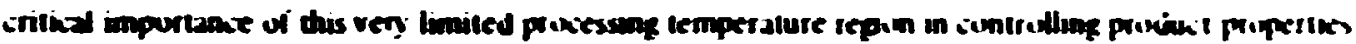

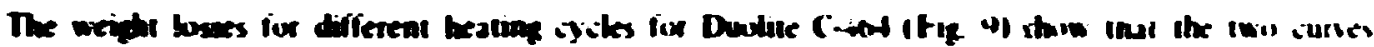

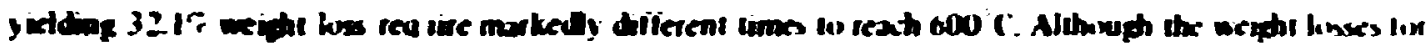

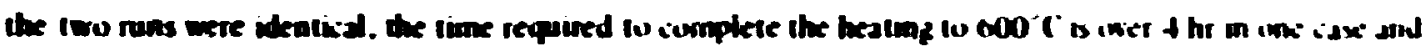
is approximately I he 10 min in the udket.

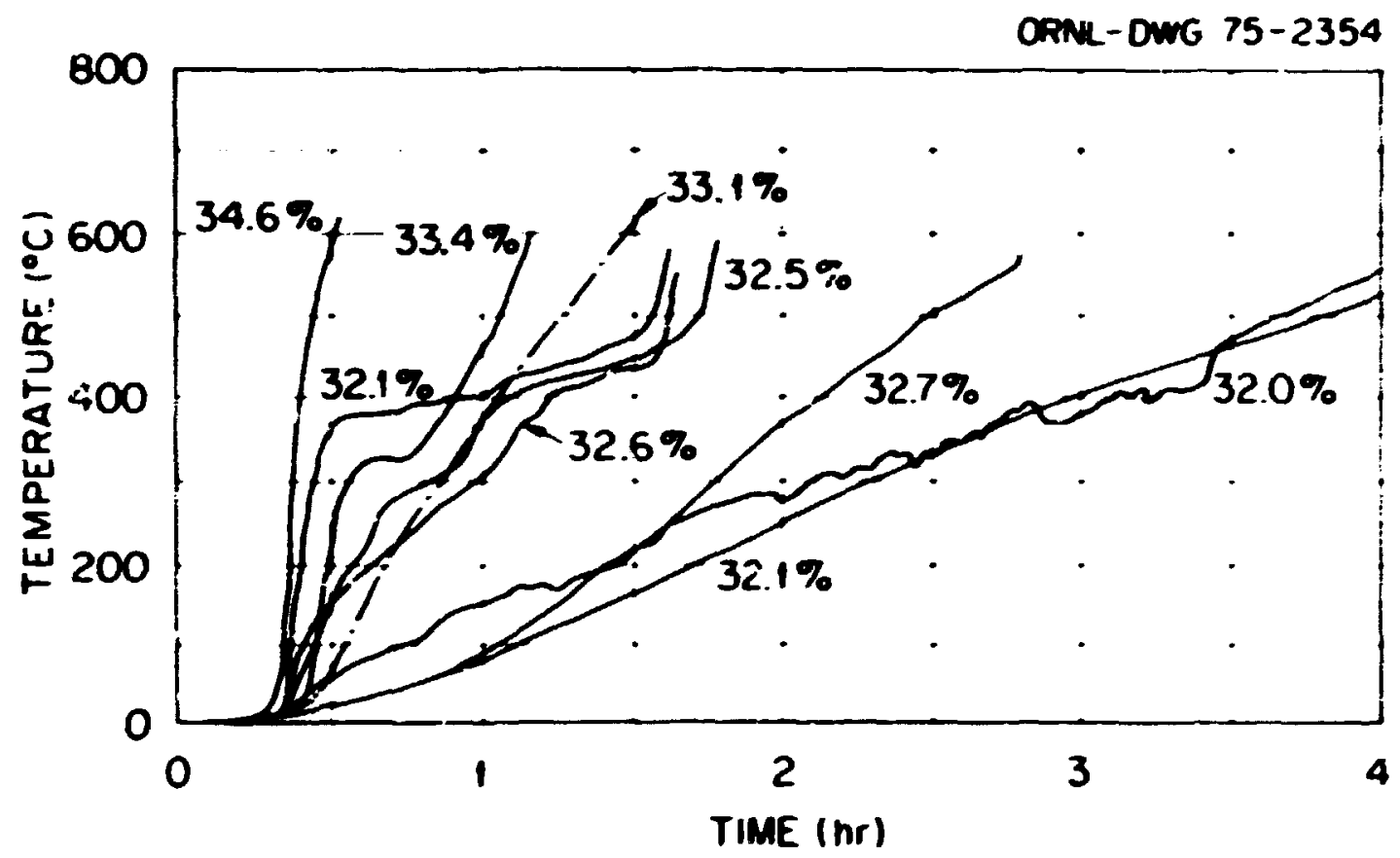

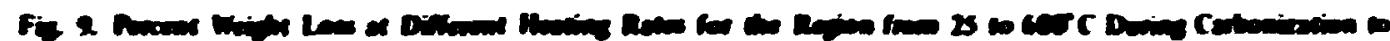

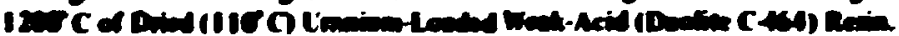

To delineate that portion of the curve whinh exerted the iarest effect in the measured parameters. Ihe

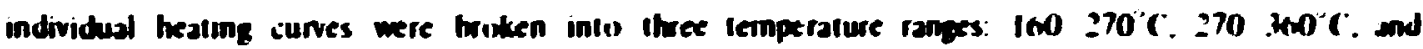
340 400 ( T Table I).

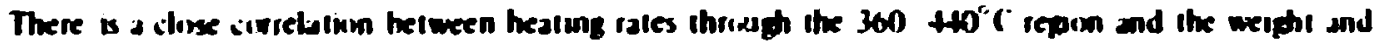

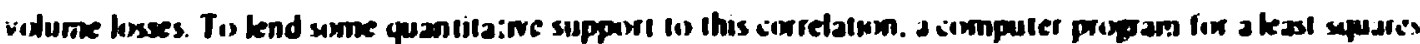

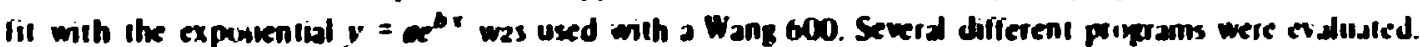

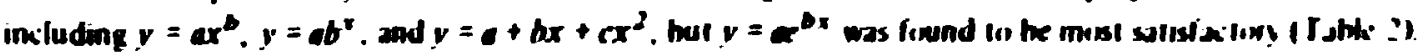

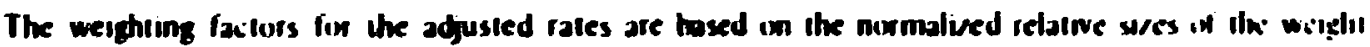

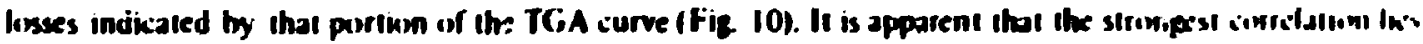

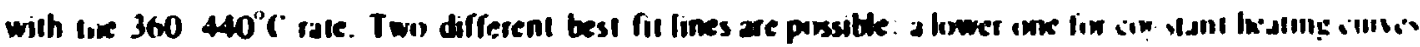

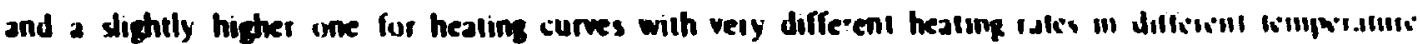

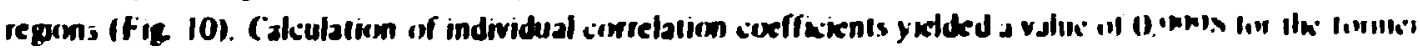
and $0 .(x) 7 k$ for the latier. 


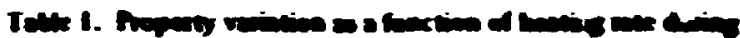

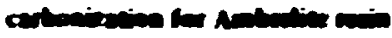

\begin{tabular}{|c|c|c|c|c|c|}
\hline \multirow{2}{*}{$\begin{array}{l}\text { bente } \\
\text { lom } \\
1 \because 1\end{array}$} & \multirow{2}{*}{ 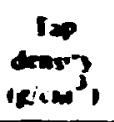 } & \multirow{2}{*}{$\begin{array}{l}\text { Vindese } \\
\text { bos } \\
\text { isi }\end{array}$} & \multicolumn{3}{|c|}{ 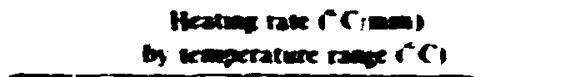 } \\
\hline & & & 140270 & 270300 & 360 \\
\hline 320 & 1.45 & $\infty .4$ & 244 & 2.00 & 133 \\
\hline 321 & 1.445 & 59.8 & 40 & 190 & 141 \\
\hline 921 & 1.40 & 59.4 & 243 & 2.47 & is \\
\hline 32.5 & 1.42 & 102 & 1017 & 472 & 2.39 \\
\hline 32.6 & 1.897 & 61.1 & 5.00 & 5.20 & 28 \\
\hline 32: & 1.491 & 60.6 & $\$ 67$ & 467 & $42 ?$ \\
\hline 33.1 & I. 4PS & 41.3 & Ist & eso & 1.00 \\
\hline 33.4 & 1.50 & 418 & 3733 & 467 & $96 ?$ \\
\hline 346 & I Ses & 4.0 & 7133 & 6267 & 62.7 \\
\hline
\end{tabular}

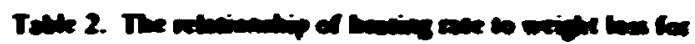

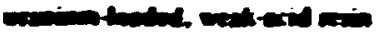

\begin{tabular}{|c|c|}
\hline Regeon & 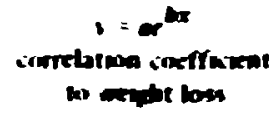 \\
\hline 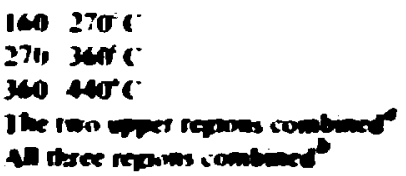 & 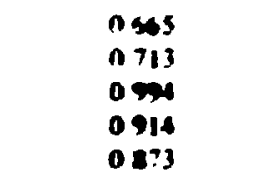 \\
\hline
\end{tabular}

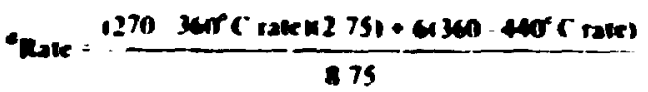

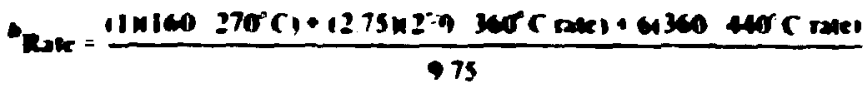

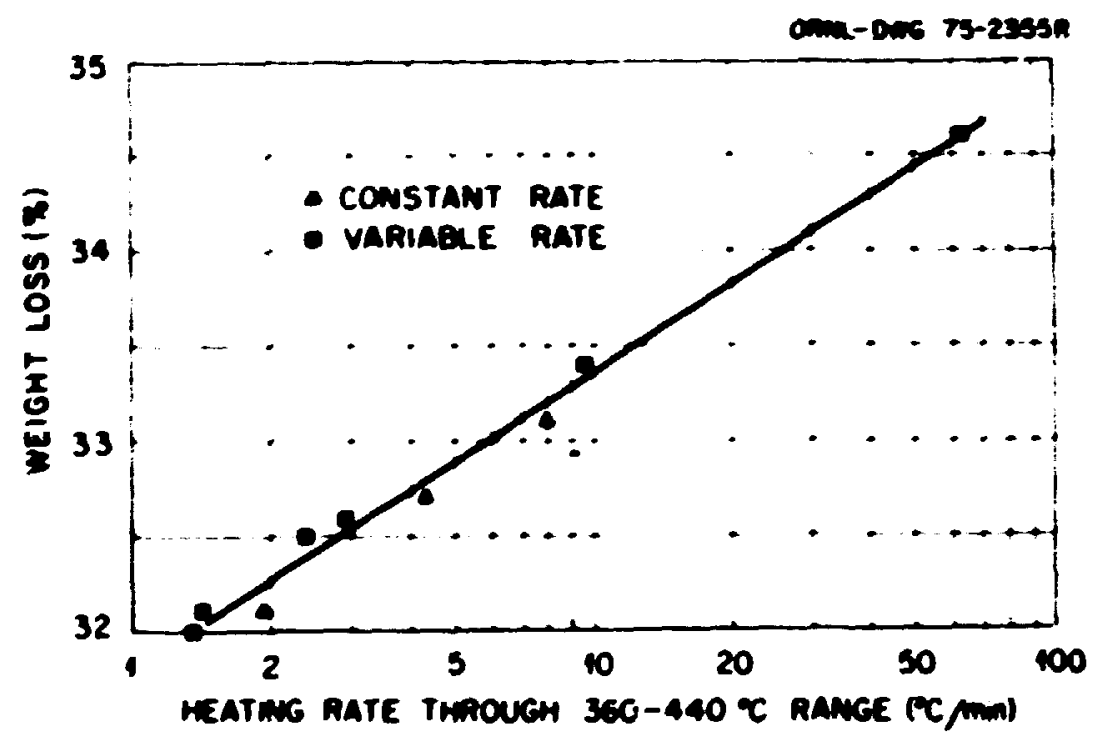

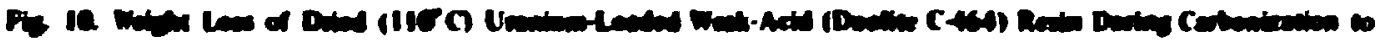

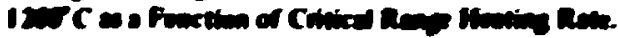




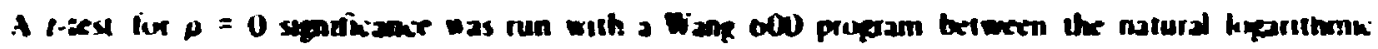
heating rale and the perient weyhe lins:

\begin{tabular}{|c|c|c|}
\hline Heatung rakes & I Value & $\begin{array}{c}\operatorname{lin} n= \\
\text {, Value tor } 0.001\end{array}$ \\
\hline Constant & $72+1$ & 31.00 \\
\hline Viaroble & 20.3 & 12.44 \\
\hline All & 23.58 & 5.40 \\
\hline
\end{tabular}

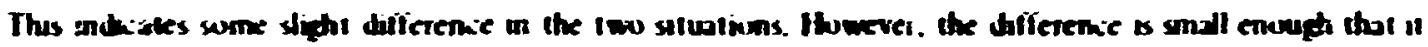
les nul warrant lut:her westigatiun.

Samilas analy ses of the rolume hass if 0.440 and 0.405 for the 360 \$0 C regeun respectivety.

65 OANL-OWG 75-2356

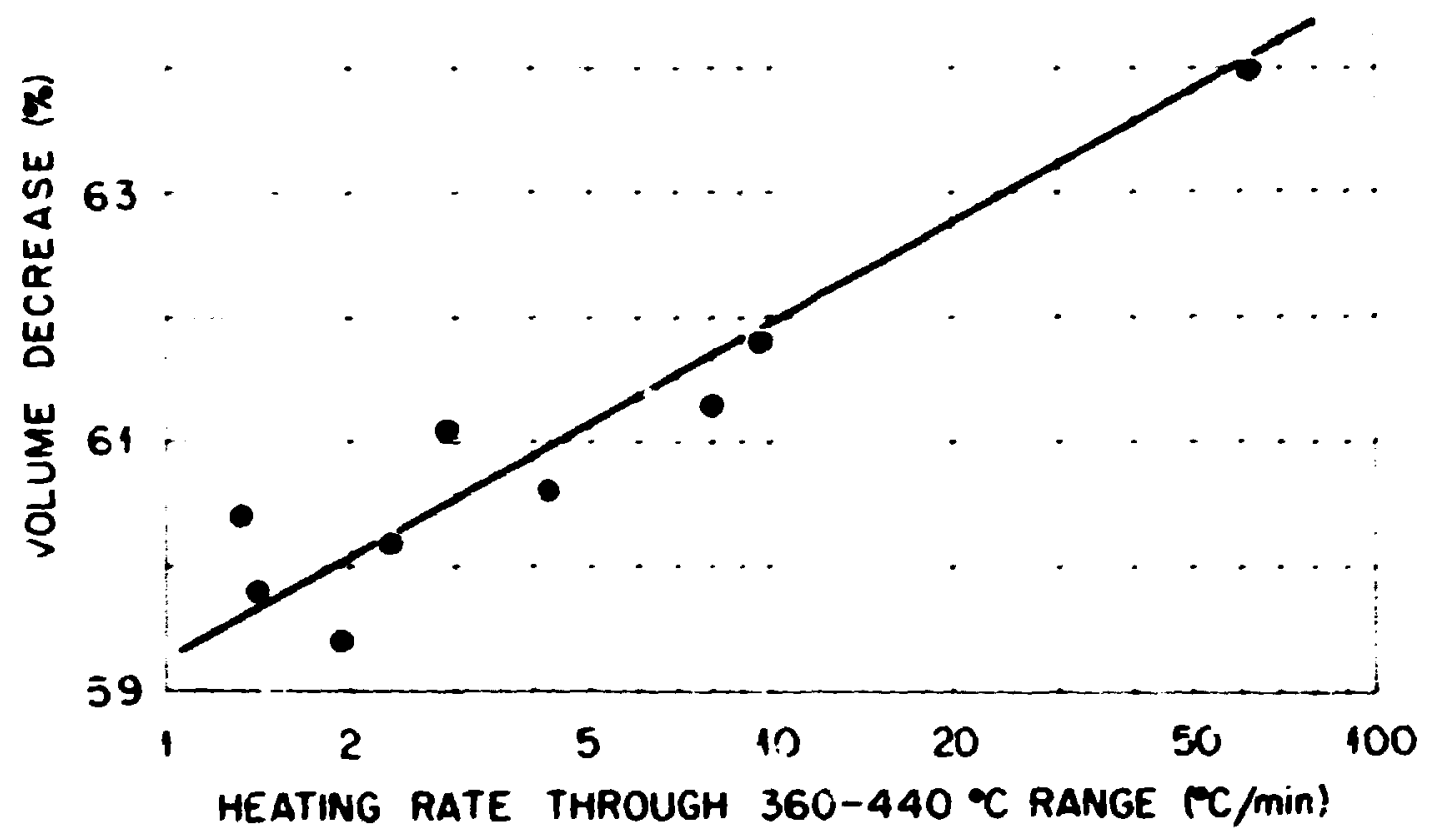

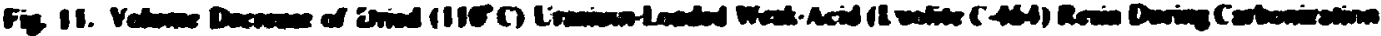

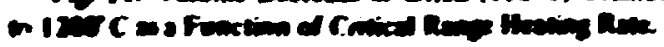

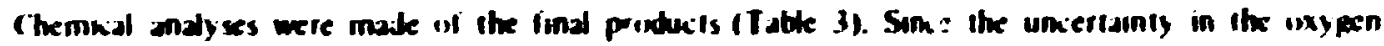

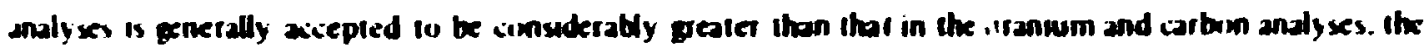

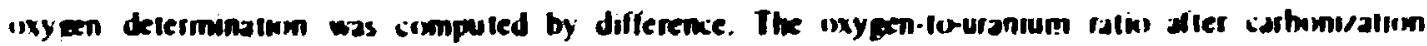
should be nearly equal to 2.00 ffor $\mathrm{CO}_{2}$. The unyeen determuned by difference is clasee to the actual value than is the andy tically devermined pericentax.

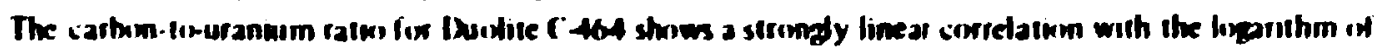

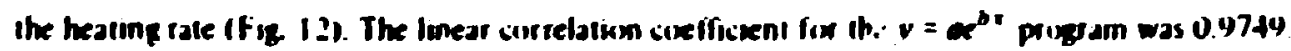




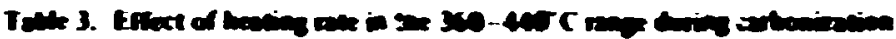

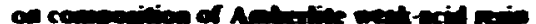

\begin{tabular}{|c|c|c|c|c|c|c|c|c|}
\hline \multirow{2}{*}{$\begin{array}{l}\text { Hestum } \\
\text { nte }\end{array}$} & \multirow{2}{*}{$\begin{array}{l}\text { Menhl } \\
\text { kns }\end{array}$} & \multicolumn{4}{|c|}{ Componstion. I } & \multicolumn{3}{|c|}{ Alomatroto } \\
\hline & & $\mathrm{c}$ & c & o & $0^{\circ}$ & $\mathbf{C u}$ & $\mathbf{O} / \mathbf{t}$ & $0 e^{-4}$ \\
\hline 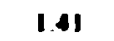 & $3 \geq 1$ & 69.68 & 21.11 & 8.53 & 921 & 6.00 & 182 & 197 \\
\hline I.94 & 32.1 & 69.49 & 21.31 & 882 & 9.27 & 6.03 & 1.89 & 197 \\
\hline 2.39 & 32.5 & 69.72 & 20.74 & 8.90 & 9.54 & 5.90 & 1.50 & 2.04 \\
\hline 2.08 & 32.6 & 70.02 & 20.2 & 8.55 & 9.69 & 5.74 & 182 & 205 \\
\hline 421 & 227 & 70.28 & 20.53 & 8.63 & 909 & 5.82 & 1.83 & $: 92$ \\
\hline 8.0 & 33.1 & 70.72 & 20.00 & 8.32 & 9.28 & 5.60 & 1.75 & 195 \\
\hline 9.67 & 33.4 & 71.06 & 19.71 & 8.4 & 9.23 & 5.50 & $1.7 ?$ & 193 \\
\hline 62.7 & 34.6 & 72.27 & Ises & 8.77 & 9.24 & 5.07 & 1.20 & 1.90 \\
\hline
\end{tabular}

by urereace.

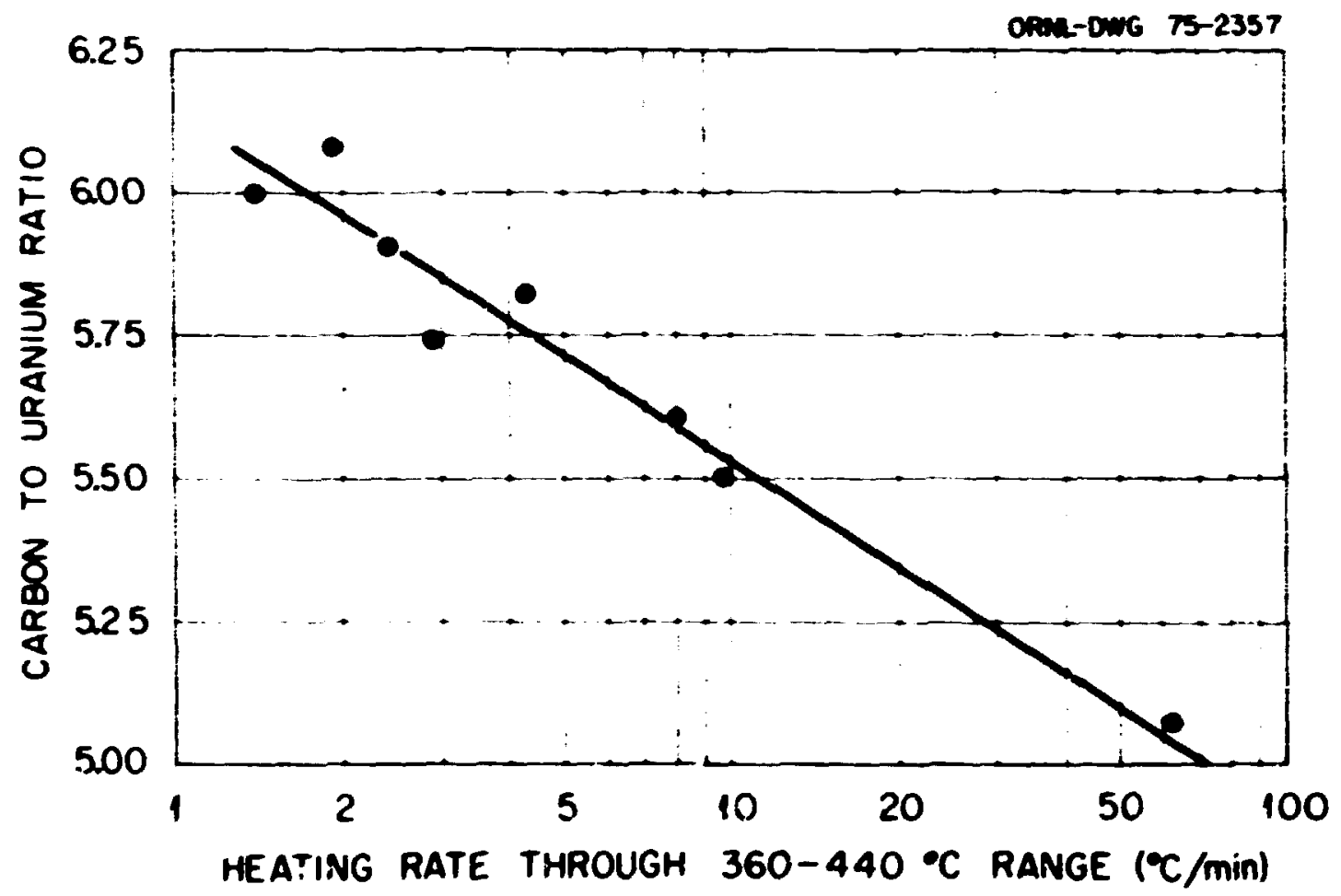

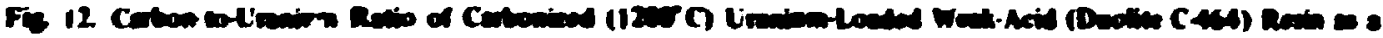

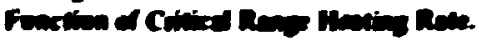

A comparison of the Uwolite and Amberlite resins $m$ the basis of carbon-to-uranium ratio (Fig 13 ) is sygnifuant since comparison runs for sticking behaviot clearly showed that carbon-to-uranium ratio has a strons effect on the bed agdometation endency at conversion lemperaturas. Dudite ( 464 resin with highet carbon-touranium ratios for equivakent heating rate is thus more readily controlled during conversion than is Amberlite IRC-72. Or course both resins stww reduced sintering and adomeration at conversion temperalutes with slower heating rates through the critical $300 \quad 440^{\circ} \mathrm{C}$ carhoniration range. 


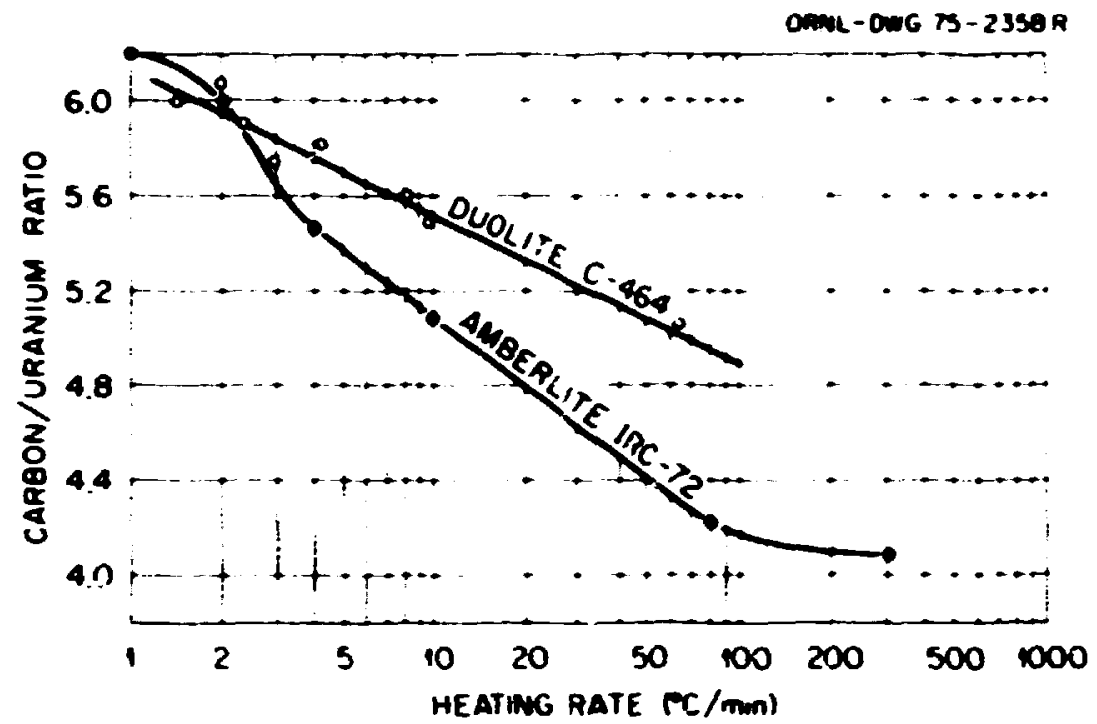

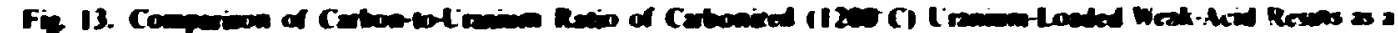

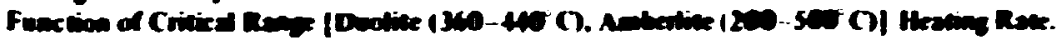

\section{Chanes in Propertios Darias Carbonintion}

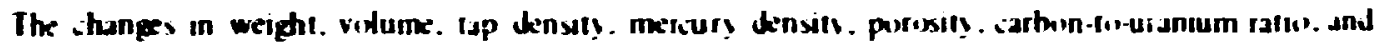

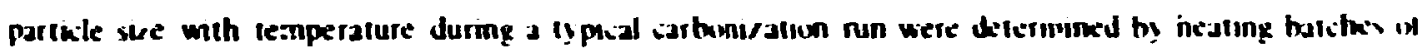

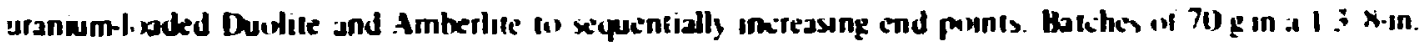

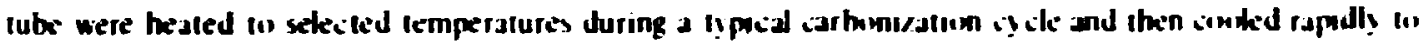
rum temperature.

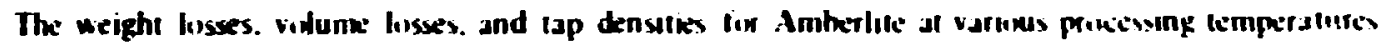

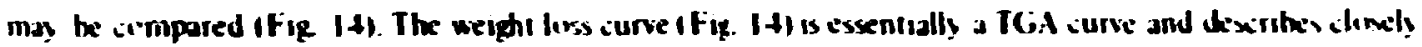

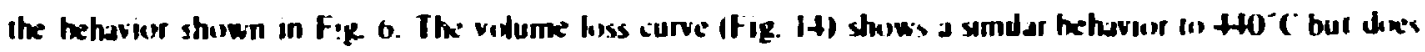

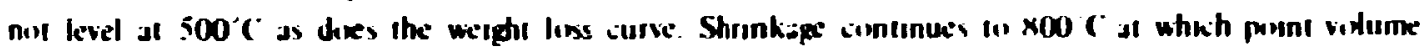

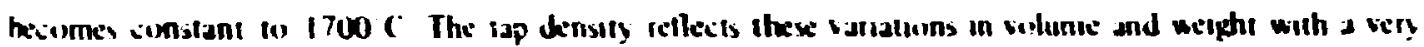

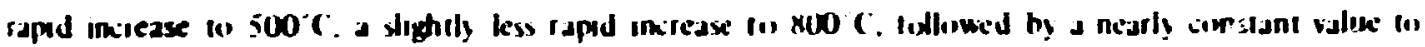

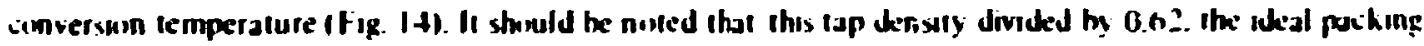
iraitun, yields an approximately ince densily.

The weight. volume. and tap densily changes with proxess lemperature for Itudite ( Hot are shown vinilarly in Fig. i5. The weight ioxs curve follows ibe T6 id curve in a manner similar (1) that observed fior

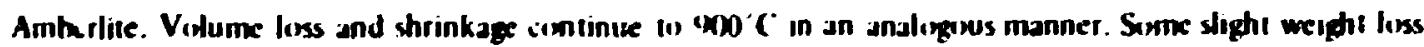

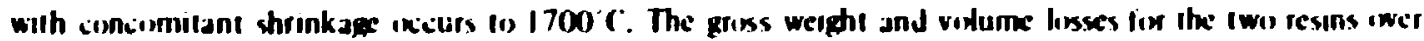
this temperature rang: are thus sumilar.

The change in partikle sie with temperature was delermined by microradingaphy. Thirly parlickes were examined in determine the average parikle ste in inkrons (Fig. It). The particle sile curve parallels

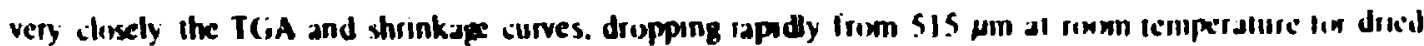

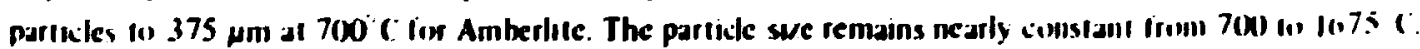

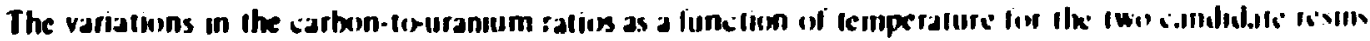

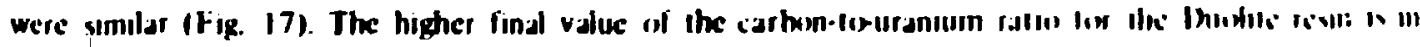
keepng with tice results pevinusly repurted on haling rate. 


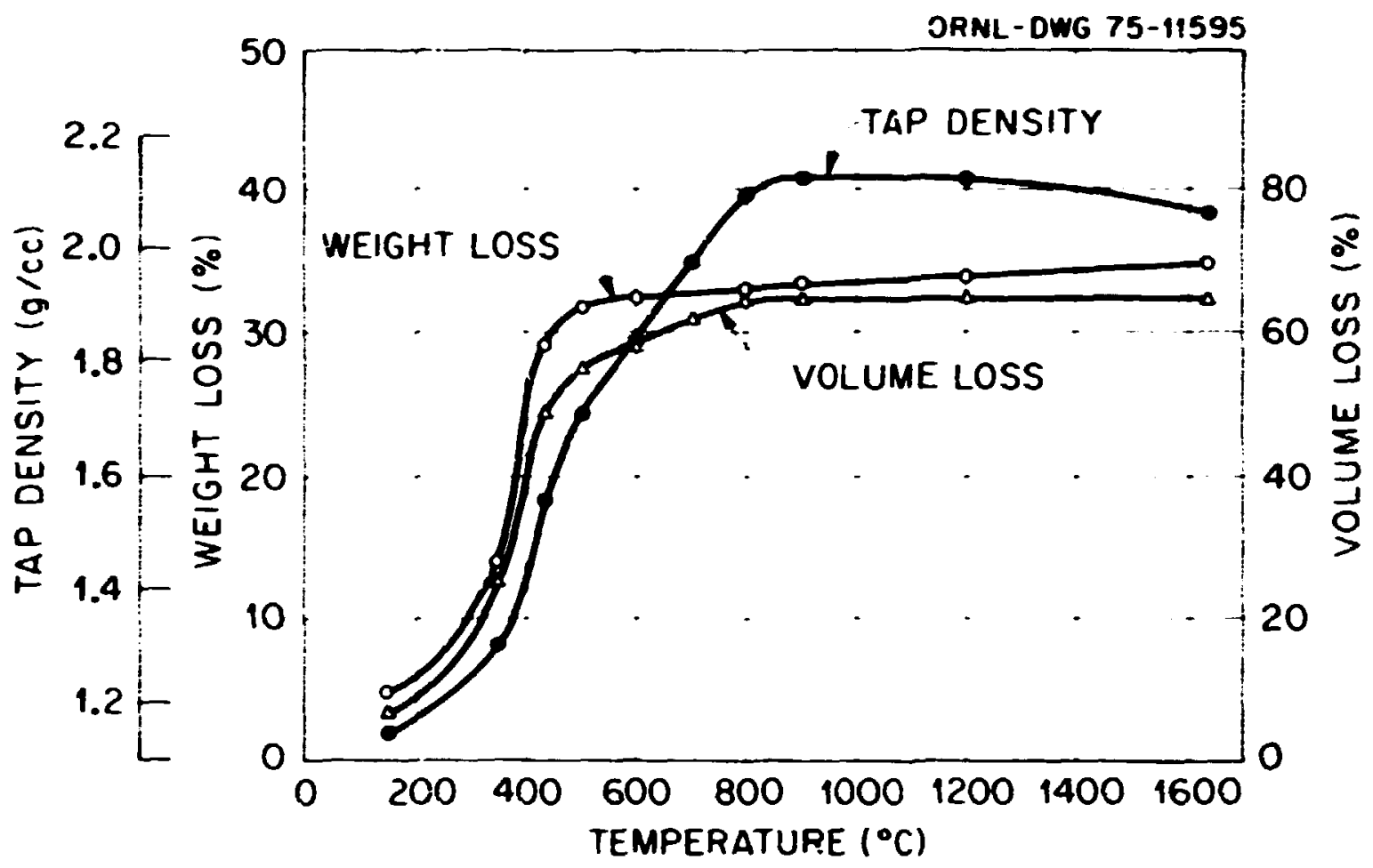

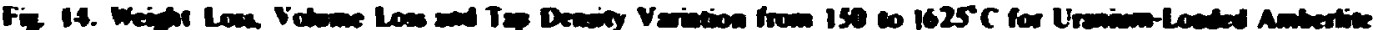
(IIAC-72) Went-Acid Resian

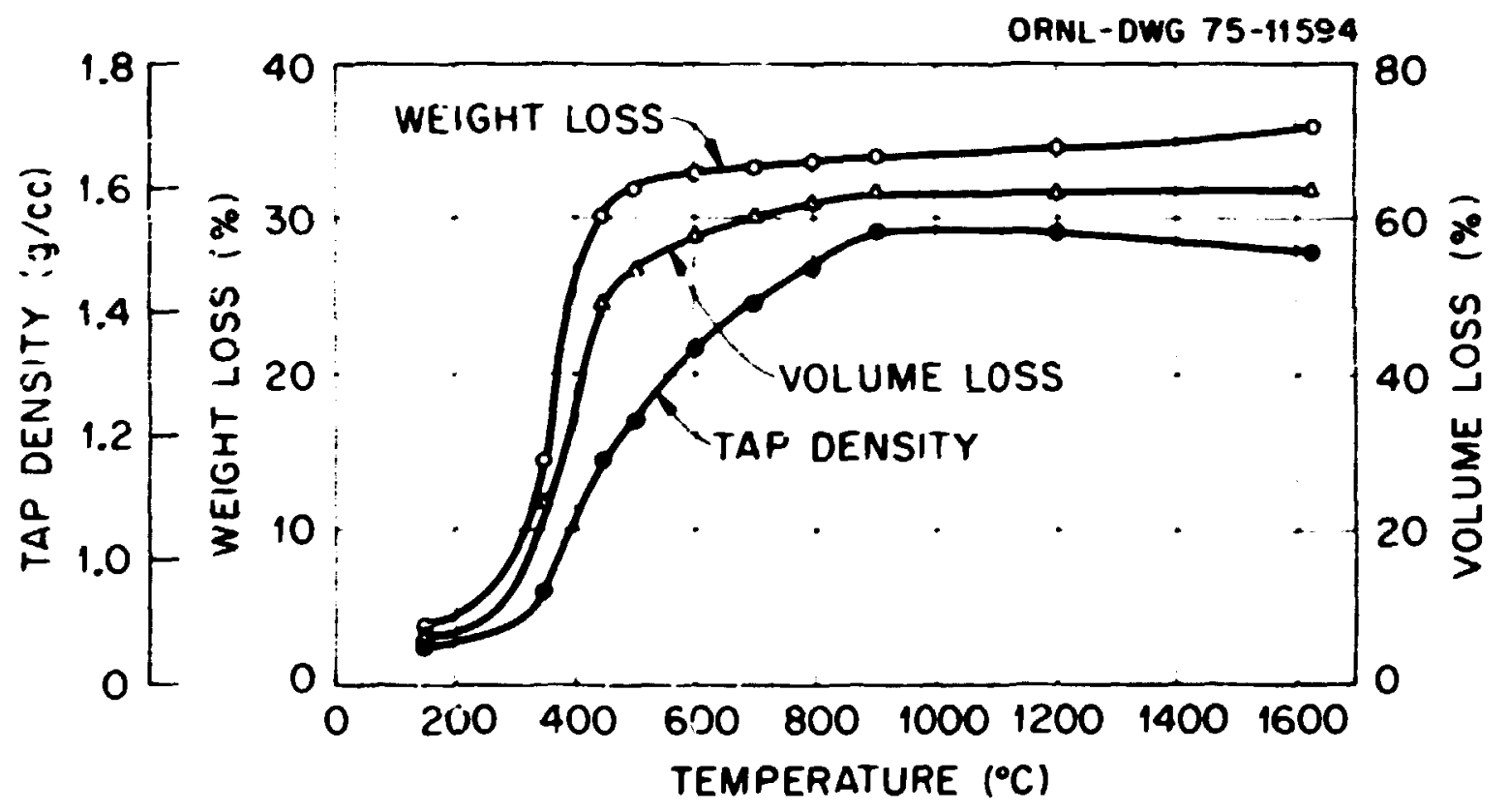

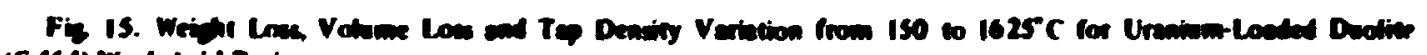
(C-14) Weat.Acid Reim. 


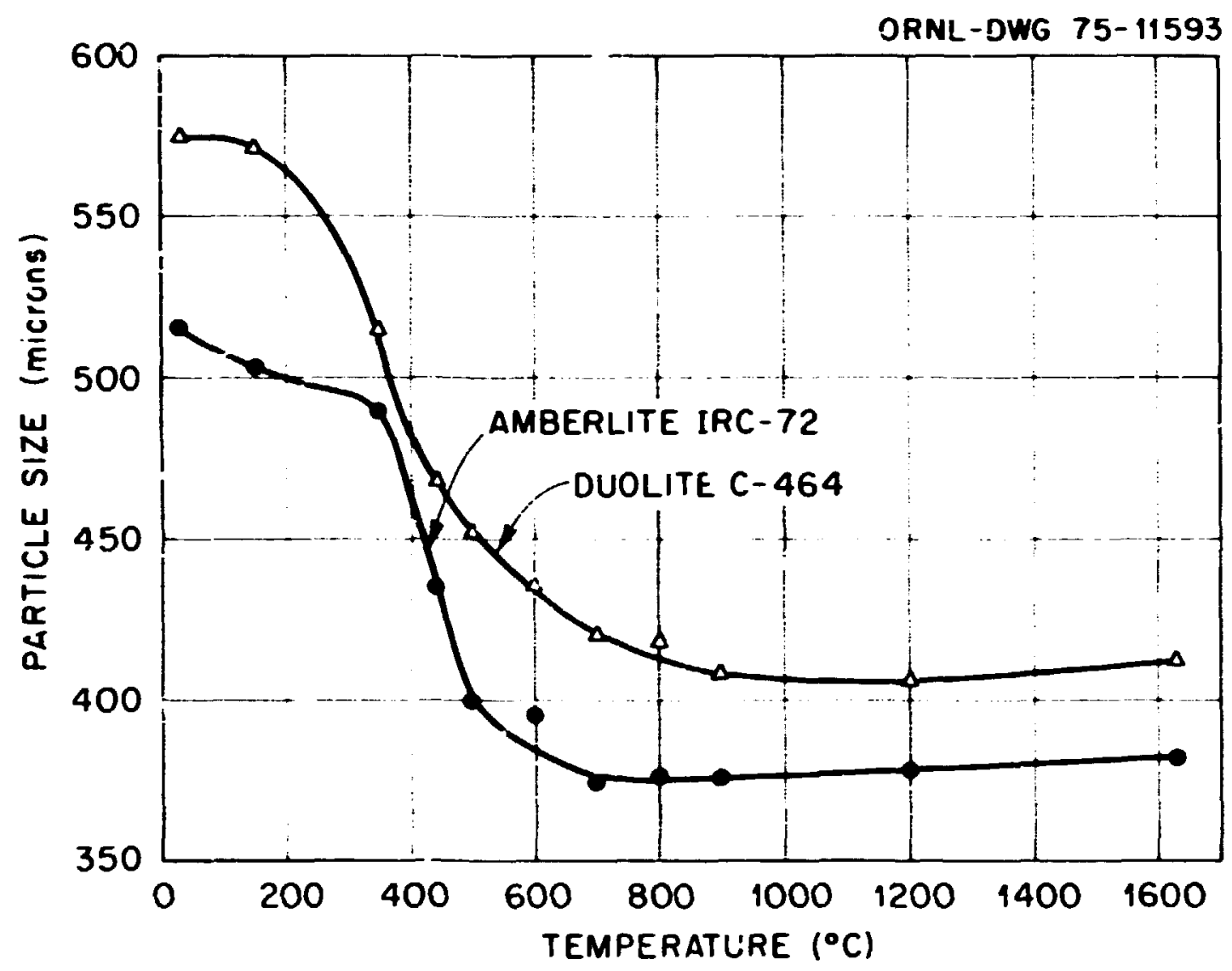

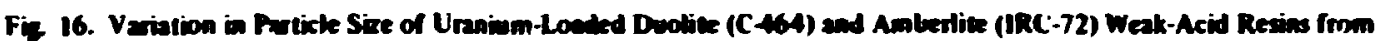
$25101625^{\circ} \mathrm{C}$.

The mercury dersity was determined at 15, 75, :50. and 15,000 psi (Fig. 18). The 15,000 psi measurements for all of the Duolite material and the first three of the Amberlite were off-scale of the mensuring device. The 15, 75, and 250 psi measurements were not significantly different for either type of resin. The mercury density again closely parallels the TGA behavior for both matcrials and is approximately $1 \mathrm{~g} / \mathrm{em}^{3}$ greater than the rof density for the 15 psi measurement. When the lap density is divided by 0.62 . the densities are essen tially the same.

Mercury porosimetry shows that the earboniled Duolite C.464 material has a pore si/e of appir)ximately $0.05 \mu \mathrm{m}$, which is significantly greater than the value of $0.015 \mu \mathrm{m}$ nbtained for Amberlite IRC.72 (Fig. 19). Both types of resin-derived fuel showed similar variations in pore size with proxess temperature from 150 io $1625^{\circ} \mathrm{C}$. Pore size decreases from 150 io $440^{\circ} \mathrm{C}$. From 440 io $1200^{\circ} \mathrm{C}$ for hoth materials. the pore size increases very slightly as the cum !lative percent porosity increases in a fairly reguiar manner. The Amberlite IRC-72 shows a decrease in pore size and percent porrosity as the temperalure increases 11$) 1625^{\circ} \mathrm{C}$ while the Duslite $(-46+$ emains c ssentially unchanged. The suggested pictur: is one in which smaller pores are operied in increasing amounts from $15010440^{\circ} \mathrm{C}$ while destructive distillation of the resin is progressing and considerable quantitics of volatiles are being liberated. From $500(1) 1200^{\circ} \mathrm{C}$, as this proiess is essentially compleic. the pores apparently coalesce and chlarge. The Duolite perrosity data are incomplete as the high-pressurs vaiues were nol ohtained due to instrument saturation.

Mrasuremeat with nitrogen of the BET surface areas al different temperatures indicaled a corresponding change with process temperature (Table 4). The surface area increases rapidly from 440 (1) 


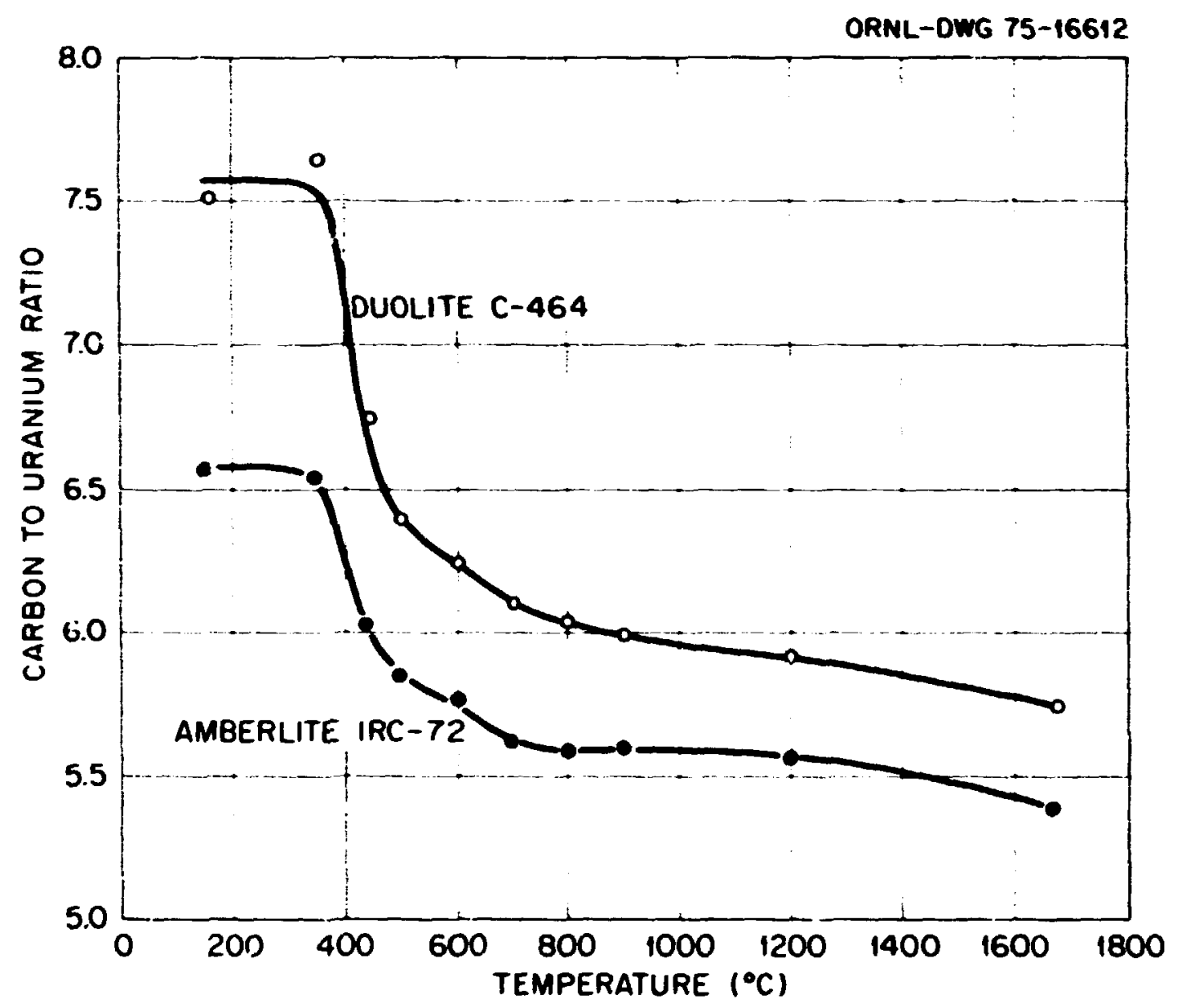

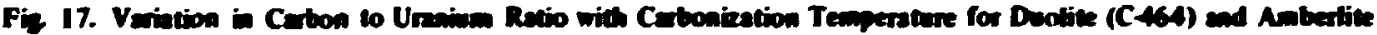
(IRC-72) Weak-Acid Resin-Derived Fuet Catbonited at $2 \mathrm{C}$ par Mis to $600 \mathrm{C}$.

$1200^{\circ} \mathrm{C}$ with a subsequent decrease to $1625^{\circ} \mathrm{C}$. Combining this information. with the pore size data indicates that from $440101200^{\circ} \mathrm{C}$ pores of virtually the same diameter increase significantly in number. from 1200 to $1625^{\circ} \mathrm{C}$. the pores coalesce to some extent with a subsequent decrease in total porosity and surface area.

The development of the $\mathrm{UO}_{2}$ phase during the carbonization process is illustrated by $\mathrm{x}$-ray powder patterns (Fig. 20). Although the $500^{\circ} \mathrm{C}$ pattern is not shown. at this remperature the phase is just beginning iv exhibit coherently diffracling regions of $\mathrm{UO}_{1}$, and the lines are very diffuse and broad. At $700^{\circ} \mathrm{C}$. the lines are still diffuse but are readily resolvable. With increasing temperature at 900 and $1200^{\circ} \mathrm{C}$, the lines hecome iacreasingly sharp and well developed as the coherently diffracting regions enlarge. At $1200^{\circ} \mathrm{C}$, the phase is clearly defined as widely dispersed $\mathrm{UO}_{2}$ crystallites.

To evaluate the crystallite size of the materiai. a stanourd of well-crystallized $\mathrm{UO}_{2}$ was gound to -325 mesh and $x$-layed in a similar manner. The line intensities and width of the standard were used to correct 


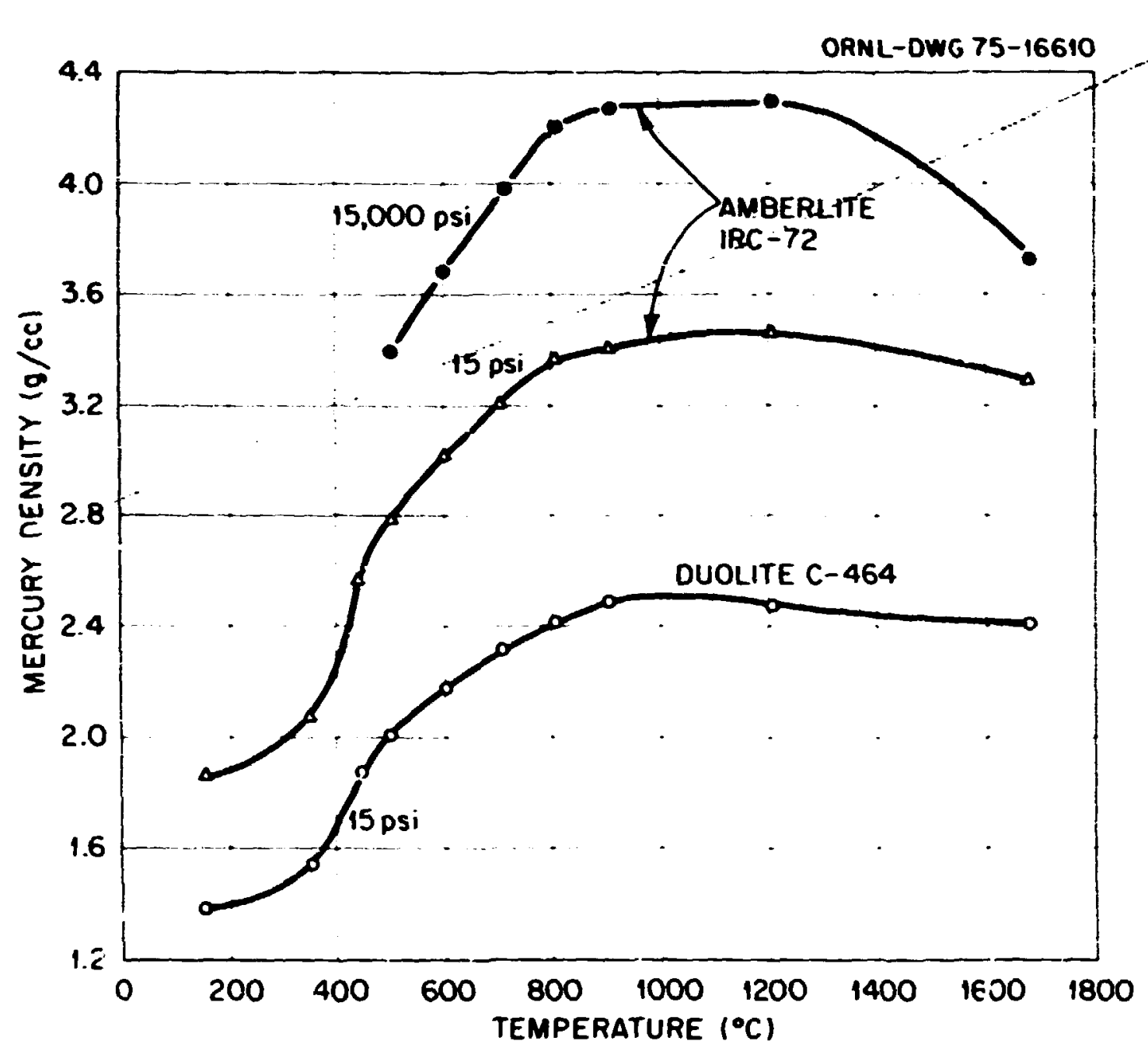

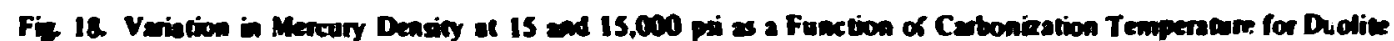

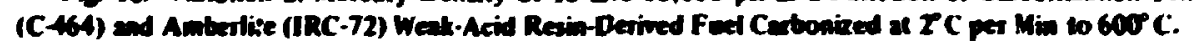

the broadening of the inlinown sample. The corrected broadening was used to calculate the crystallite size for specific refleitions from: the Scherrer formula 14

$$
i=\frac{C_{\lambda}}{B \cos \theta_{\beta}}
$$

where

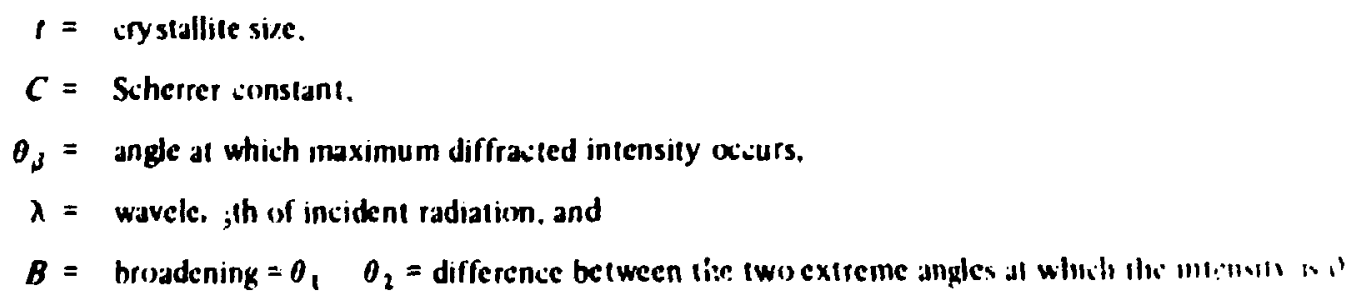

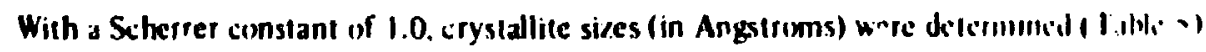




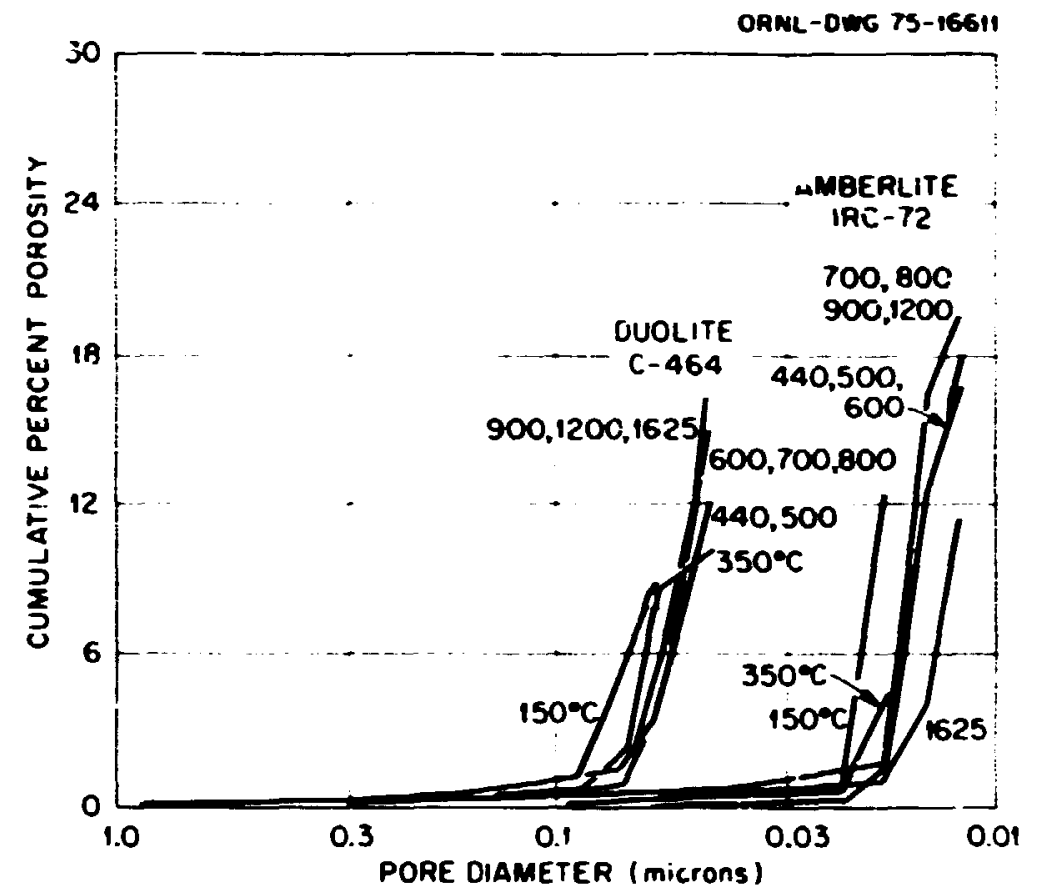

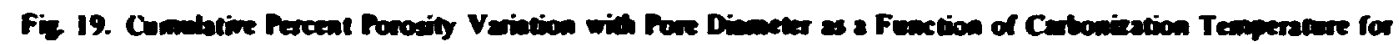

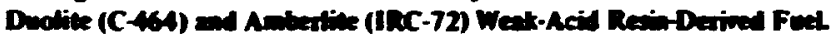

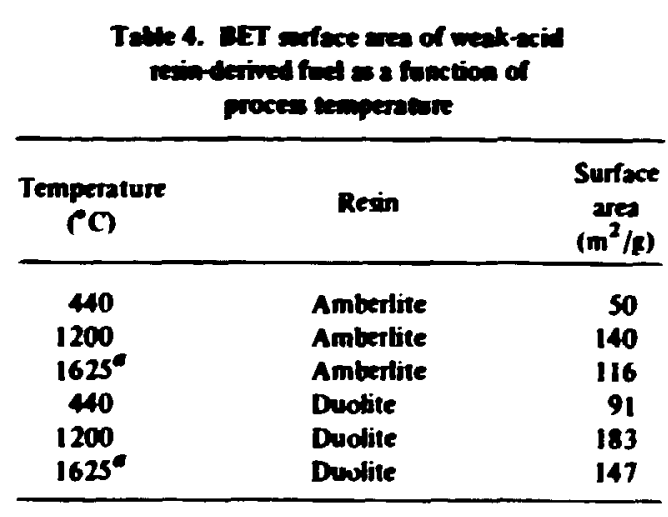

To approximately 100 s conversion.

The eneral increase in size with increasing temperature is appasent. The crystallites of $\mathrm{UO}_{2} \mathrm{it}$. carbonized material, even allowing for experimental uncertinty well above the anticipated $\pm 5 A$ in the above results, are thus apparently less than $100 \mathrm{~A}$ in size and finely disper sed through a porous carbun matrix.

\section{Other Carbonization Process Purameters and Uranivm Loss}

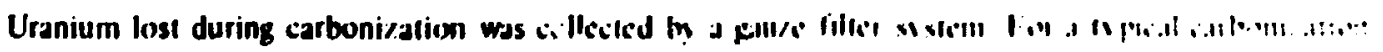

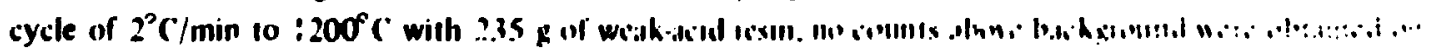

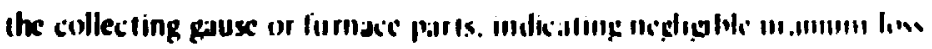




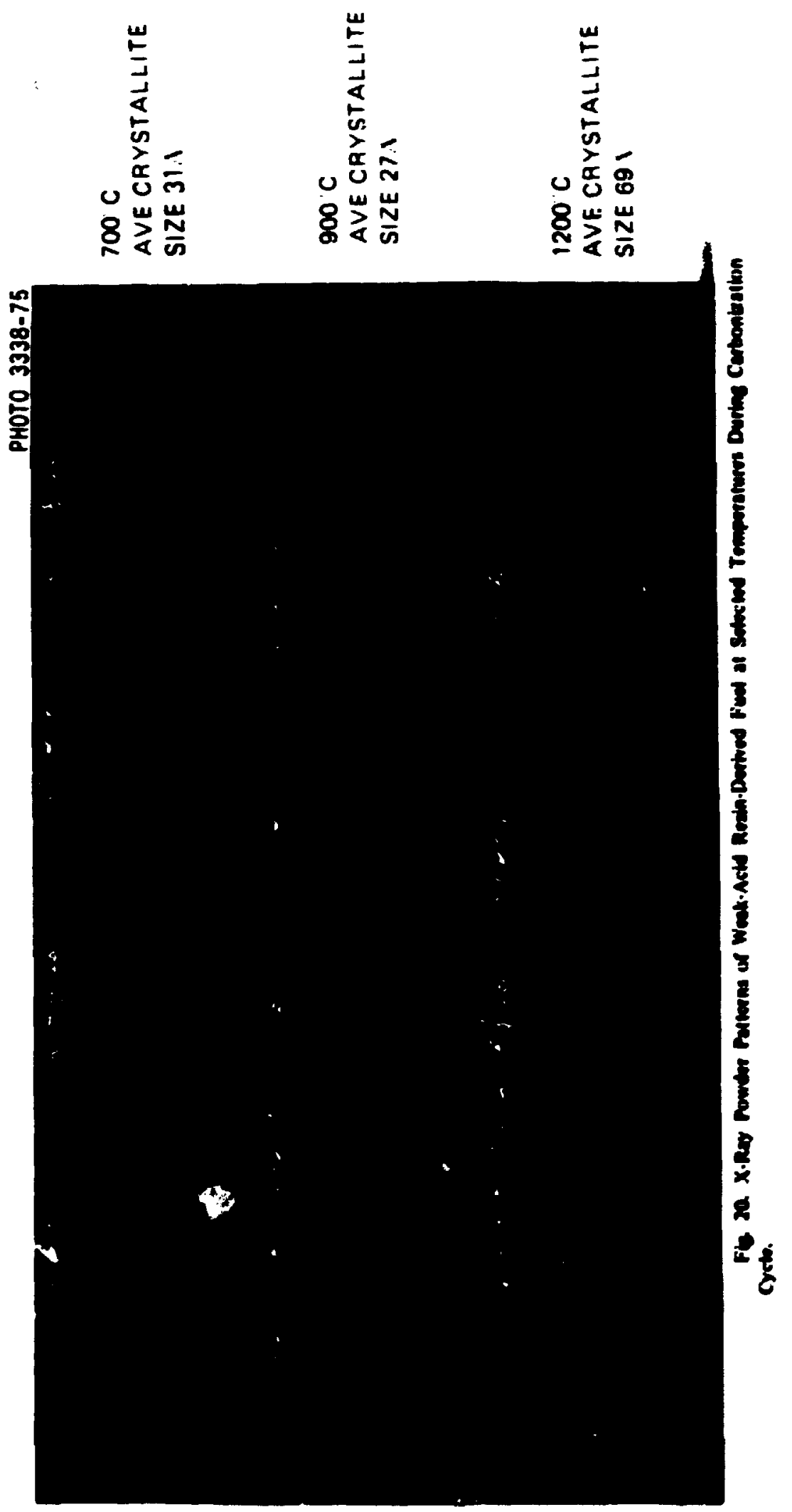




\begin{tabular}{|c|c|c|c|c|c|}
\hline \multirow{2}{*}{ Smopte } & \multirow{2}{*}{$\begin{array}{c}\text { Tenperature } \\
\text { (1) }\end{array}$} & \multicolumn{4}{|c|}{ Crystabie me. A } \\
\hline & & 1111 & 12001 & 12201 & Avesax \\
\hline It - 279 & sid & 21 & 26 & 16 & 21 \\
\hline 14. -223 & $? 00$ & 38 & 35 & 29 & 31 \\
\hline If:-225 & 900 & 25 & 25 & 31 & 27 \\
\hline If.-2en & 1200 & $\pi$ & 66 & 70 & 69 \\
\hline
\end{tabular}

A carbunuation cycik on the $150 \mathrm{~g}$ batch at $170^{\circ} \mathrm{C}$ min $101200^{\circ} \mathrm{C}$ yietded the following counts Idus mul an the fumace parts flfig 5 .

Sipht port tuhe

Furnace hd

Ciraphtite tobe alapter and insert pieces
$1+46$

13 s.

3030

The collection gauc and the wipess used in the turnace compunents wete ashed and analyzed lis uranum. Approximutely $15.3 \mathrm{mg}$ of uranium was obtained which represents abuut 0.02 : of the total uisnum in the bolich. Although this puhably des not represent complete collection. it is indiative of the uranium less during a ven fast carbmivation sycle. Iteme. the slow cabunivation used lo maximize the carthm-(1-uranium ratiu) is alsu advantagerus in avoding process luss of uranium.

Alernate arbuniotion media were investigated by replaving the argon fluidizing gas with air to aburt 270 C. the litst upaiticant T6A reaition, in with hydropen thloride to 500 C to improve the carhm-l(t-uranium ratiu) as sugested by Bacun.' 3

When air was used. the partikles were obxerved to chang colox at 270 C $\mathrm{C}$ in a normal mannet as the air was replaced in argon at that temperature. Subseyuent bed behavior retating to the onset of initial smaking. and heavy romking indivated that ail exposurc had raised the temperatures of these events by $20^{\prime} \mathrm{C}$. This temperature $\left.1270^{\circ} \mathrm{C}\right)$ was identifed as being the maximum feasibie temperature for using air as a Muidivine pas. Tenuperatures abuve $\mathbf{2 \$ 0} \mathrm{C}$ produced rapid oxidation. Analyses of material in which air was suhstituled for argun is 270 ( may be compared with dala from an otherwise ideritial control run ( Tabke n). The substitution of ait for argun in the initial staps of carbunication does not appear to produce a sponikiantly different nacerial. Althust ow increase in carbun-lu-uranium ratio was produced. replaring with air the large votume of argen required to fluidice a bohth to 250 to $270^{\circ} \mathrm{C}$ will some muncy.

Replacing arpon with hydrogen shloride to $500^{\circ} \mathrm{C}$ raised the cemperature at which the physically ibservable bed changes incurred by abuut $501060^{\circ} \mathrm{C}$. However. a yellowish film formed on the sight plass and fumace lid at apposximately 1080 to $1100^{\circ}$. This film diseppeared when exposed (1) air. Examination with an alpha counker howed the residue to have a sipnificant contamination kevel. probably of uranium. Adjusiment of the heating procedure from 800 10 $1200^{\circ} \mathrm{C}$ did not climinate retease of this materia. Fxiensive attaik on the andined aluminum fumaie parts was observed The results of analyses on these botches (Table 7 thw the adracias of increasing the carbon-lu-uranum atio by 0.5 by additions of hy dionen chloride in be fat cutweiphed by utanium release and altaik on furnace ports. The exposure behovius of the normal and air-ubstituted material to ar was escenicialiy identical. The hydropen churide exposed material displayed considerably less apparent westht pin with time. However. this hehoviu was altribuled to the liberation of considerabte amounts of hydrosen chloride andion uranium cintainine volatike species during oxidation. 


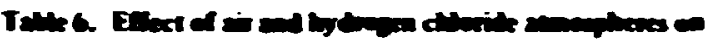

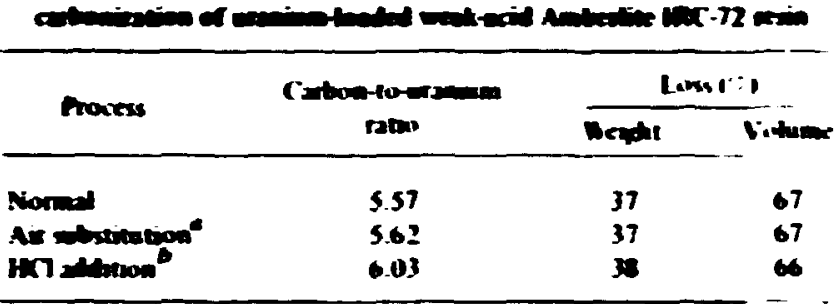

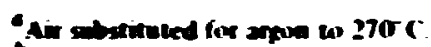

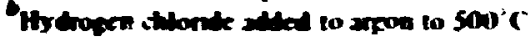

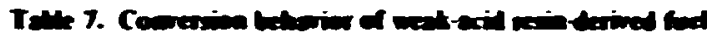

\begin{tabular}{|c|c|c|c|c|c|c|}
\hline $\begin{array}{l}\text { Type } \\
\text { moletio }\end{array}$ & $\begin{array}{l}\text { victate } \\
\text { aremiates } \\
\text { (c) }\end{array}$ & $\begin{array}{l}\text { As/l } \\
\text { |lif| }\end{array}$ & $\begin{array}{l}\text { Netueat } \\
\text { cosver:was }\end{array}$ & $\begin{array}{l}175 \\
\left.\because \mid 0^{\circ}\right)\end{array}$ & $\begin{array}{l}\text { Tube } \\
\text { dounctet } \\
\text { ine I }\end{array}$ & 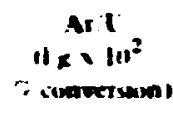 \\
\hline$A^{*}$ & 37.7 & 0.66 & 43.6 & 5.133 & 138 & 152 \\
\hline$A$ & S0.7 & 5.36 & 43.4 & 5.640 & 134 & 124 \\
\hline$A$ & S1.t & 1.09 & 6.3 & 5.269 & 134 & 1.64 \\
\hline$A$ & 54.0 & I.5s & 57.8 & 5.339 & 134 & 2.69 \\
\hline$A$ & 50.5 & 5.63 & 37.3 & 5.624 & $13 / 4$ & 15.1 \\
\hline$A$ & 45.5 & 1.23 & 56.8 & 5.260 & 134 & 216 \\
\hline$A$ & 66.7 & 1.10 & 77.7 & $5.2 n \times 1$ & 1318 & 142 \\
\hline A & 485.7 & 0.53 & 25.5 & S.2100 & $+1 / 4$ & 2.117 \\
\hline$\wedge$ & 32.8 & 2.19 & 932 & 5.269 & 13,8 & 235 \\
\hline$D^{h}$ & Sn.5 & 0.71 & +6.2 & 5.269 & 134 & 154 \\
\hline D & IS2.5 & 0.88 & $\$ 1.3$ & 5.269 & 13 it & 218 \\
\hline D & ISO.t & 1.02 & 45.t & 5.269 & $13 / 4$ & 2.24 \\
\hline D & 56.2 & 1.02 & 63.6 & 5.269 & $13: 4$ & 160 \\
\hline D & 55.7 & 102 & 688 & 5.269 & $13 / 4$ & 1.49 \\
\hline$A$ & 272.1 & .2 .61 & 50.8 & 5.2000 & $41 / 4$ & 1.19 \\
\hline A & 41.9 & 1.91 & 39.4 & 5.495 & $13 / 4$ & 4.85 \\
\hline$A$ & 87.2 & 0.22 & 39.9 & 5.339 & $21 / 2$ & 2.07 \\
\hline A & 117.1 & 0.85 & 27.1 & 5.485 & $21 / 2$ & 3.15 \\
\hline A & 1548 & 0.45 & 45.0 & 5.200 & 212 & $0: 49$ \\
\hline A & 154.4 & 0.45 & 43.6 & 5200 & 2112 & 1.03 \\
\hline$\wedge$ & 107.9 & 1.22 & 35.0 & 5.411 & $13 / 4$ & 3.48 \\
\hline A & 28.1 & 2.24 & $\$ 7.9$ & 5.411 & $13 ; \cdot$ & 4.49 \\
\hline A & $10 ? .4$ & 2.20 & 53.4 & 5411 & 13,4 & 4.12 \\
\hline A & 29.0 & 1.24 & 35.6 & 5.411 & $13 / 4$ & 3.49 \\
\hline A & 103.2 & 1.22 & 35.1 & 5.411 & $13 / 4$ & 3.47 \\
\hline A & 28.9 & 1.25 & 29.7 & 5.411 & $13 / 4$ & $4.2 i$ \\
\hline A & So.4 & 4.23 & 31.7 & 5.562 & $13 / 4$ & 1 3.35 \\
\hline A & 57.5 & 412 & 4.6 & S.562 & $13 / 4$ & $9 ? 3$ \\
\hline$A$ & 57.8 & 3.94 & $\$ 3.9$ & 5362 & $13 / 4$ & 8.97 \\
\hline A & 57.8 & 2.41 & 53.9 & 5.441 & $13 / 4$ & 4.47 \\
\hline A & 57.4 & 2.40 & 39.0 & 541 & $13 / 4$ & h. Is \\
\hline A & 57.1 & 2.41 & 39.6 & 5.411 & $13 / 4$ & 6.108 \\
\hline A & 120.5 & 0.52 & 48.7 & 5.094 & $13 / 4$ & 1.07 \\
\hline A & 57.5 & 5.22 & 47.5 & 5562 & $13 / 4$ & 10.98 \\
\hline$A$ & 57.4 & 7.37 & 72.0 & 5.361 & $13 / 4$ & 1024 \\
\hline
\end{tabular}

-Amberlite IRC.72. Rr 'm and Haxs

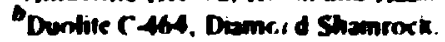




\section{Cherges in Prepertios Darmg Conversion}

The thange, in vitumk. Weight. and cunverson level at $16: 5$ C atker carbunisation at 2-C men fix

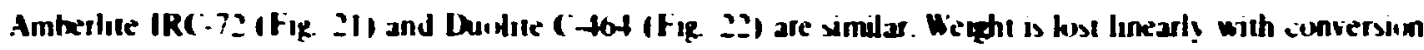

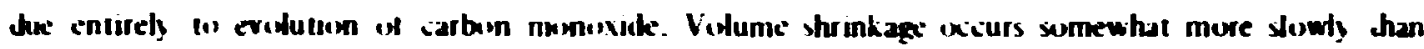
weight liss. and is nell neciessally linear with converswon. The volume stability to abuul 25't conversion lullowed by a rate of shrinkage lewer than the gate of weight luss pruduces a minimum in the tap density lin buth materials at approximatets $\mathbf{5 0}$; cimversiun. Extended time at temperature beyond full conversion

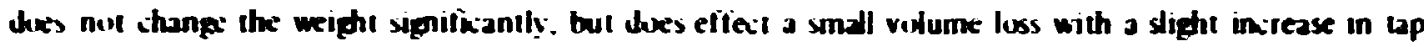
censity. The weipht-luss point ior the 45 '-ionver'ed Durlite (Fig 22) is anomalows in that it shows an impussible weight gin with in-reasing conversinn level.

As expected, the variation in particle sive with comersion level (Fig. 23) is similar to that seen for the volume loss. The data sugest a po sible volume maximum at approximately 25 ; conversion. However. this result is difficult to rationalice so further work on this is needed to better define the pre...se manner in which partikle diameter and volume shange with conversion.

The mercury density variation with conversion level was measured (Fig. 241 except for the 15.000 psi values lirr Dudite $f-t+4$ whih were not obtained as the values were off-scale on the measuring device. The

ORNL-DWE 76-5445A

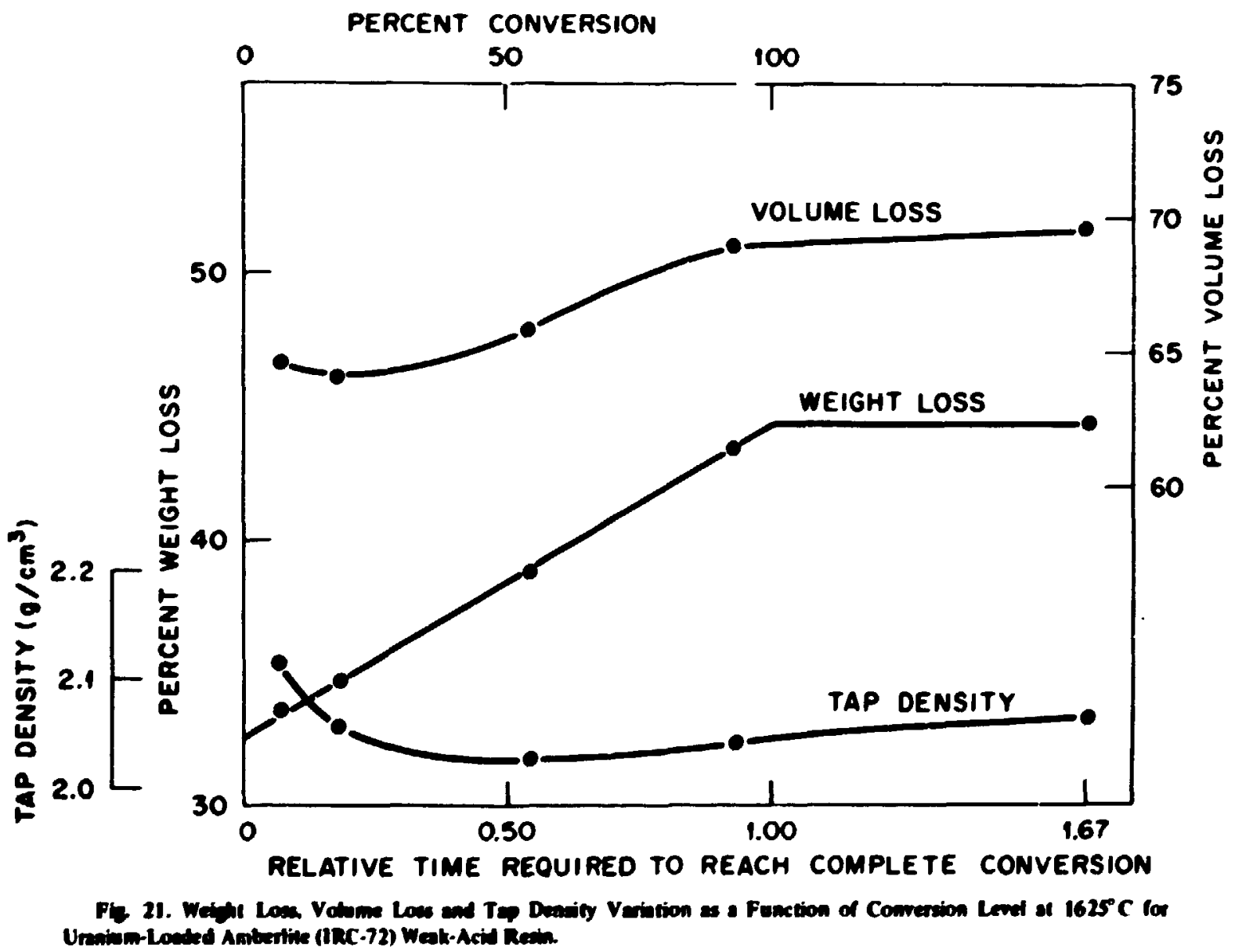
Unaiman-Londed Ambertive (IRC.72) Weat-Acid Reats. 


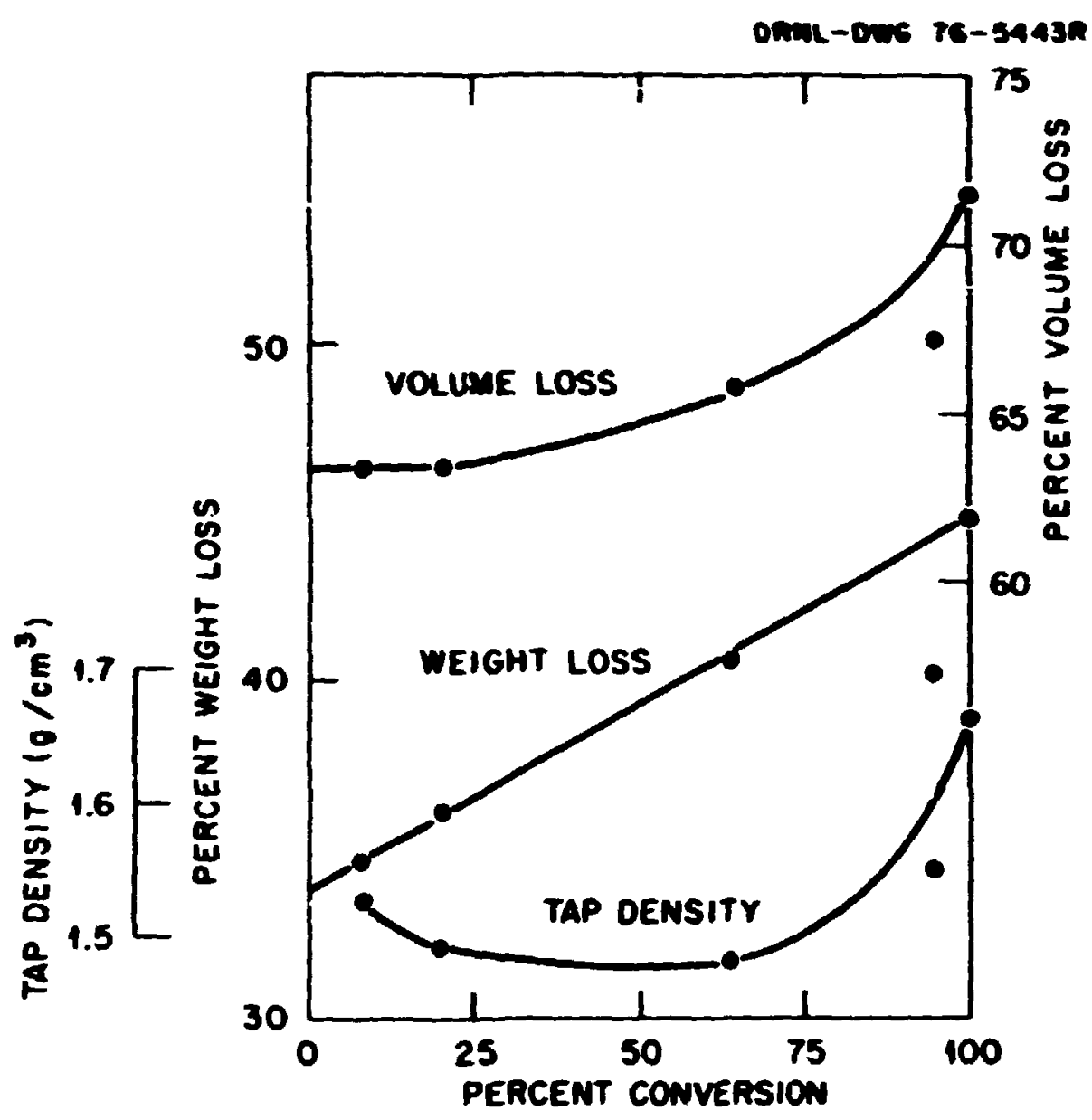

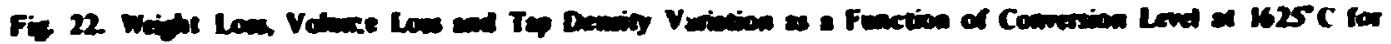

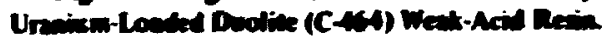

15, 75 , and 250 psi values were not significantly different and are shown as a single value. The variation closely follows that obeerved for the tap density with a minimum at approximately 25 to 307 conversion. The 15,000 psi Amberlite curve is not conclusive due to the small number of points but does shuw a similar tendency. The values for the tap density divided by $\mathbf{0 . 6 2}$. the ideal packing fraction. are essentially identical to those oblained by 15, 75, and 250 pai mercury.

The pore size distribution in nominally $35 \%$ converted material a determined by mercury porosumetry (Fig 25) shows the Dudite resin to have a wide range of pore sizes with the najority lying between 0.10 and $0.015 \mu \mathrm{m}$ with an equal distribution between 0.05 and $0.025 \mu \mathrm{m}$. The Ambertite has a much mure restricied pore size with virtually all pores smaller than $0.16 \mathrm{~mm}$. Both resins approach an ultimale apparent density (to $15.000 \mathrm{psi}$ mercury) of approximately $3.9 \mathrm{~g} / \mathrm{cm}^{3}$ for the carbonization conditions employed in this study.

\section{Comverion Rete and Thermodymanies}

The extent of conversion of weak-axid-resin derived fuet was found to be controlled by the temperature and specific gas now. The specific gas flow is cakculated as liters of argon per gam of uranium nurmalised to pet cent conversion obtained. The conversion betavion of different sited batches at different 


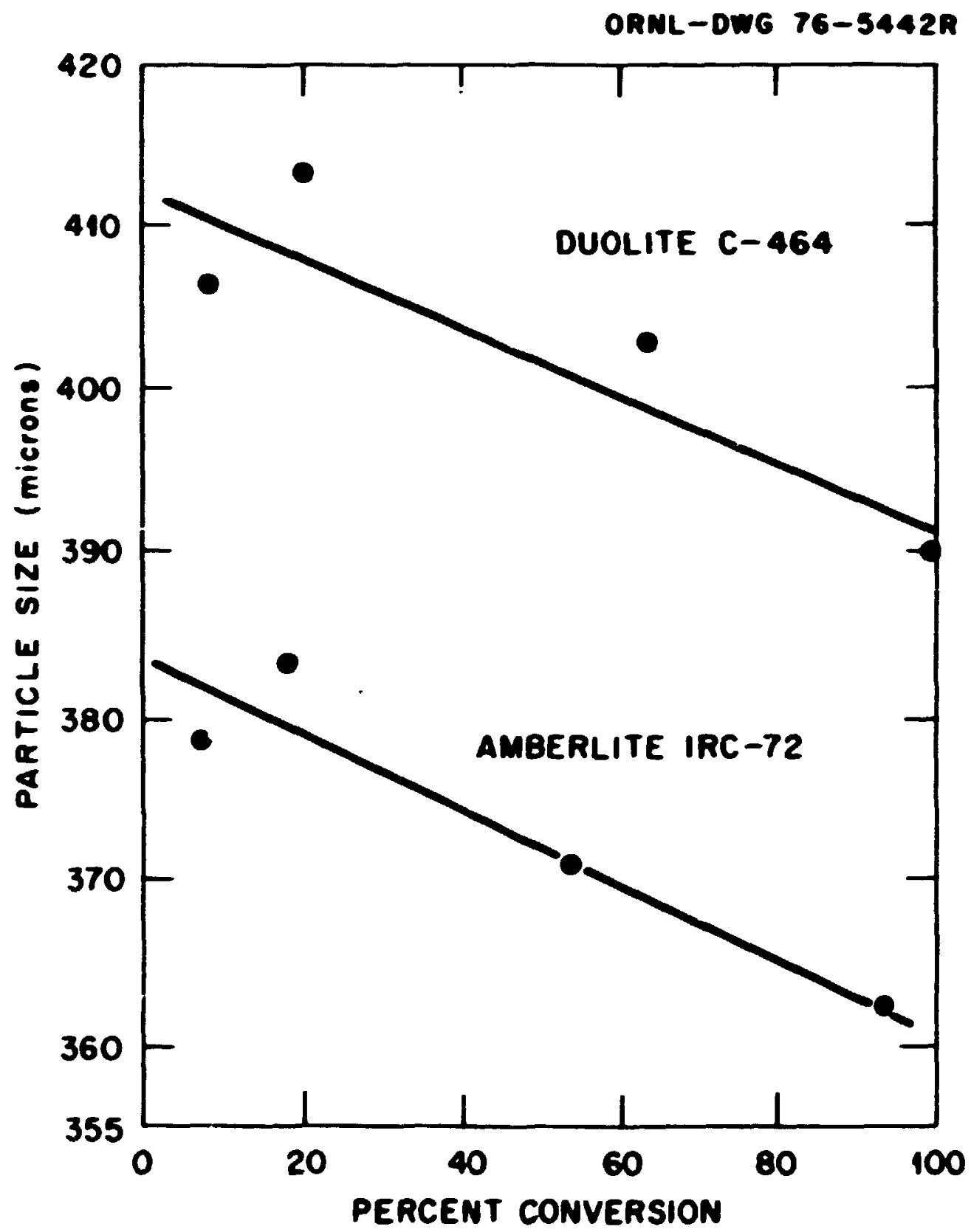

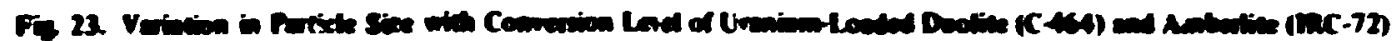

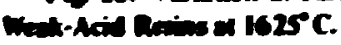

lemperatures and gas flows s shown in Table 7. The vatation with semperaturc is shown in Figure 26 with a regresion line fit for $y=a x^{\prime \prime}$ with a corretation coeffnient of r.945 shown as a dached line. The pertinent reacion curve predicied from thermodynamics is shown as a solid line. Duolite and Amberlite resins were nut significantly different.

These results indicaled that convetsion is occurring to a somewhat greater extent than is predicted from classial bulk thermodynamis." This behovior could be altributed to 27 ir contributions from the small 


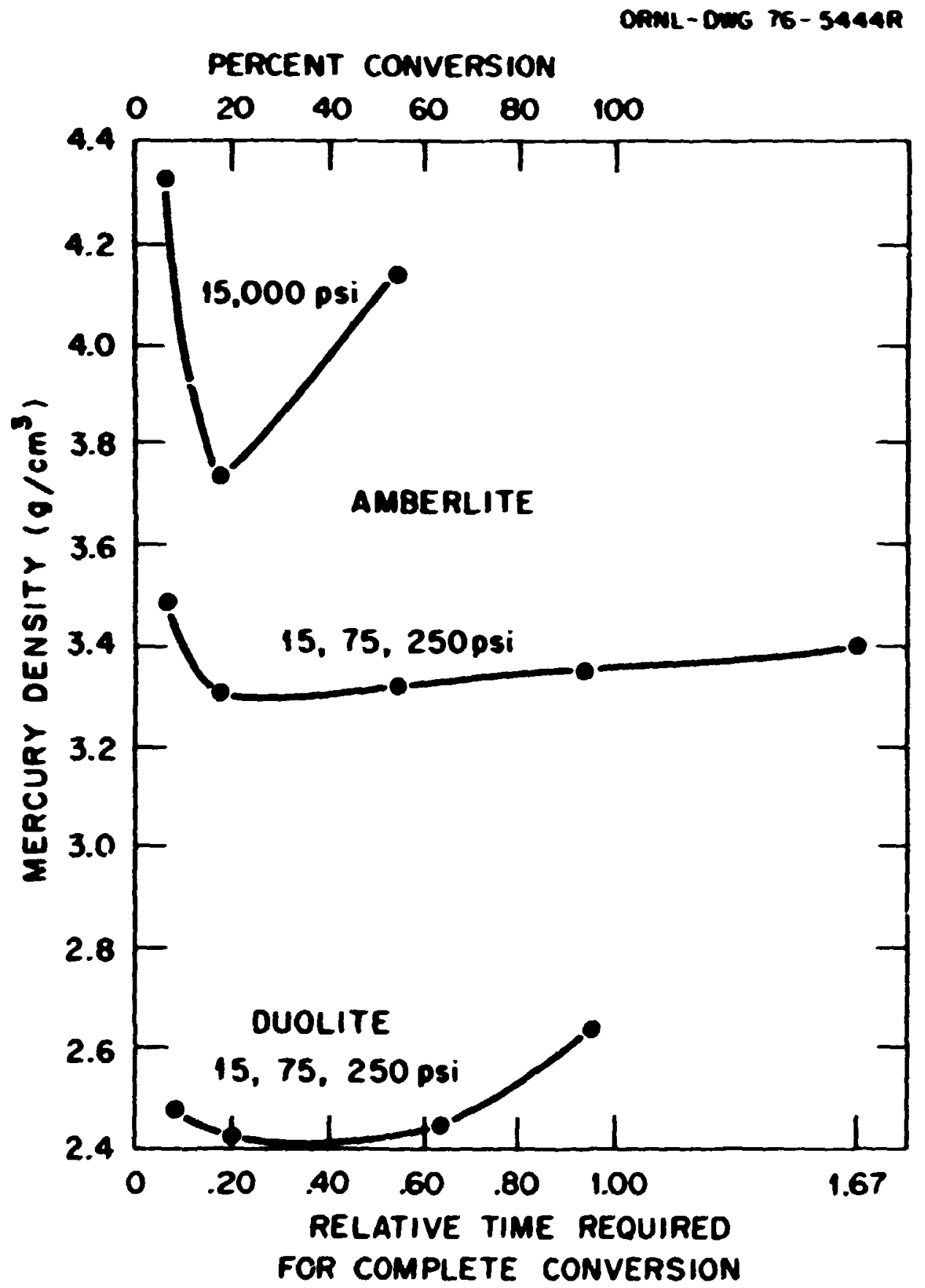

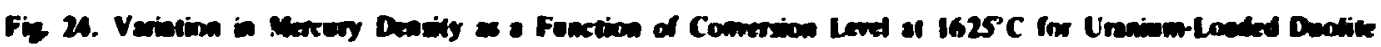

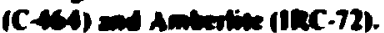

curvature radius of the pores. where $\gamma$ is the surface free energ and $r$ the radius of curvature: other contributions could be due to temperature messuring error or to a second reation ociurring at a significantly geater rate at higher temperatures.

Paralel temperature measurements carried out with a platinum us $\mathrm{h} 10 \mathrm{H}$ h thermoxiouple in the bed differed from an optical pyrometer reading on the outside tube wall opposice the thermoxouple by 
OANL-OWG 76-9736

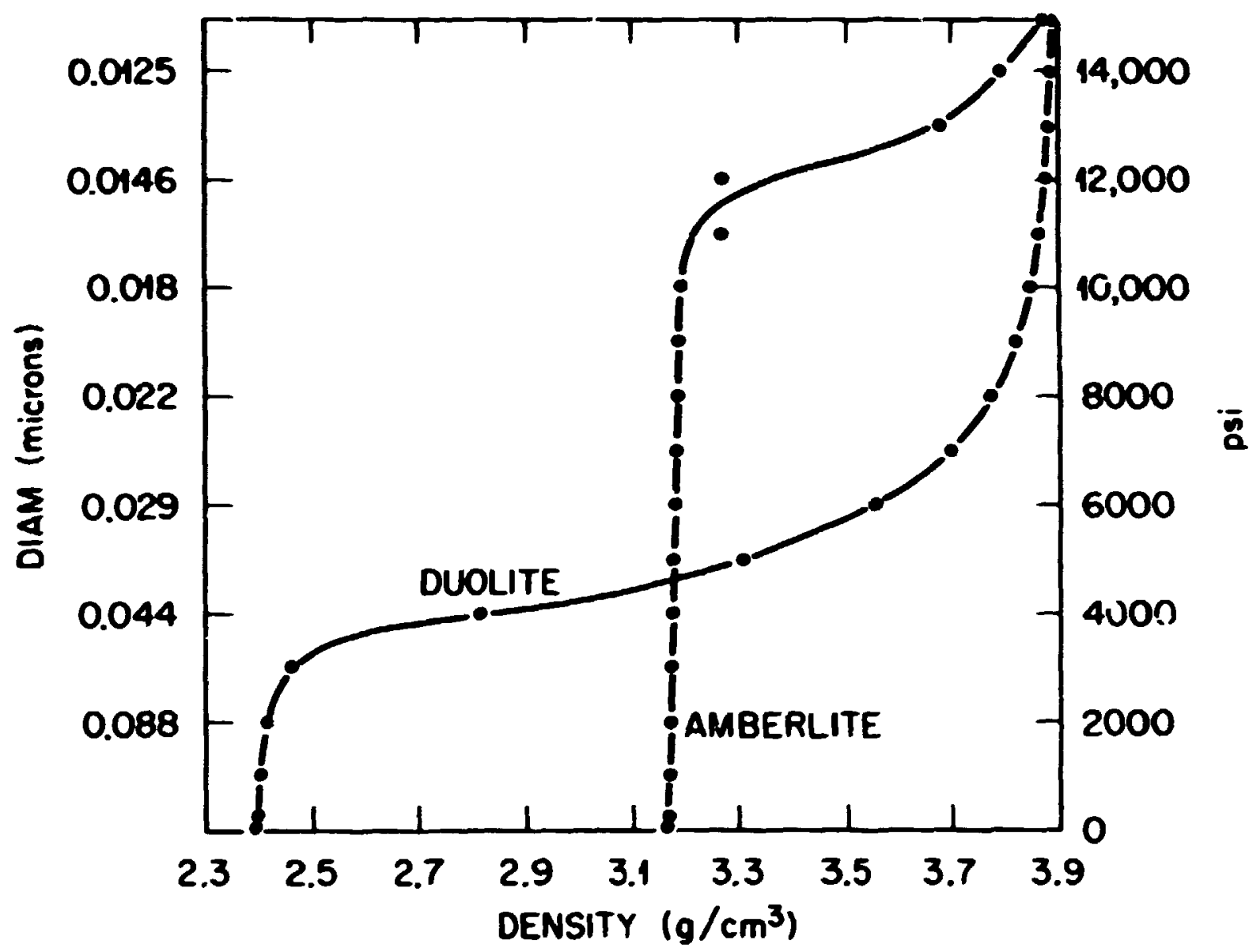

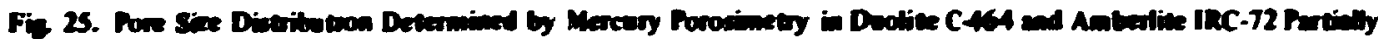
Comerted Weat-Acid Rexin

$+19.1^{\circ} \mathrm{C}$. and by $-6.9^{\circ} \mathrm{C}$ relative to an optical reading of $1450^{\circ} \mathrm{C}$ at the control sight purt on the tubs wall. The temperature divergence between the experimental data and the therniodynamic values of $8^{\circ}$ at $1525^{\circ} \mathrm{C}$ and $54^{\circ}$ at $1665^{\circ} \mathrm{C}$ (Fig. 26) can be attributed therafore, in part, to the enror in measuring true effective bed iemperature with an optical pyrometet on the exterior tube wall.

Our recent data indicate that conversion of up $107 \%$ is occurring at $1200^{\circ} \mathrm{C}$. considerably below the predicted reaction region. This behavior, possibly due to the $2 \gamma / r$ contribution to the free energy from the sunall $(\sim 0.015$ to $0.05 \mu \mathrm{m}$ diam) porosity in i.te kernels. is apparently less important since pores may be sealed off rapidly at $1200^{\circ} \mathrm{C}$ unce this kevel of convergion is obtained. This factor may be significant in the apparent conversion rate discrepancy.

A second conversion reaction may increase to enlarge the divergence of the predicted and experimental values. As will be shown later, conversion of $\mathrm{UO}_{2}$ to $\mathrm{UC}_{1-x} \mathrm{O}_{x}$ proceeds at increasing rates relative to the $\mathrm{UO}_{2} \rightarrow \mathrm{UC}_{2}$ reaction as the temperature goes up.

The effect of fluidizing condition on the effective bed temperature and the measured bed temperature is sig ficant in controlling conversion levels obtained for different runs or in different equipment. Parallet bed thermocouple and optical wall temperature measurements for various fluidizing conditior:- (Fig. 27) 


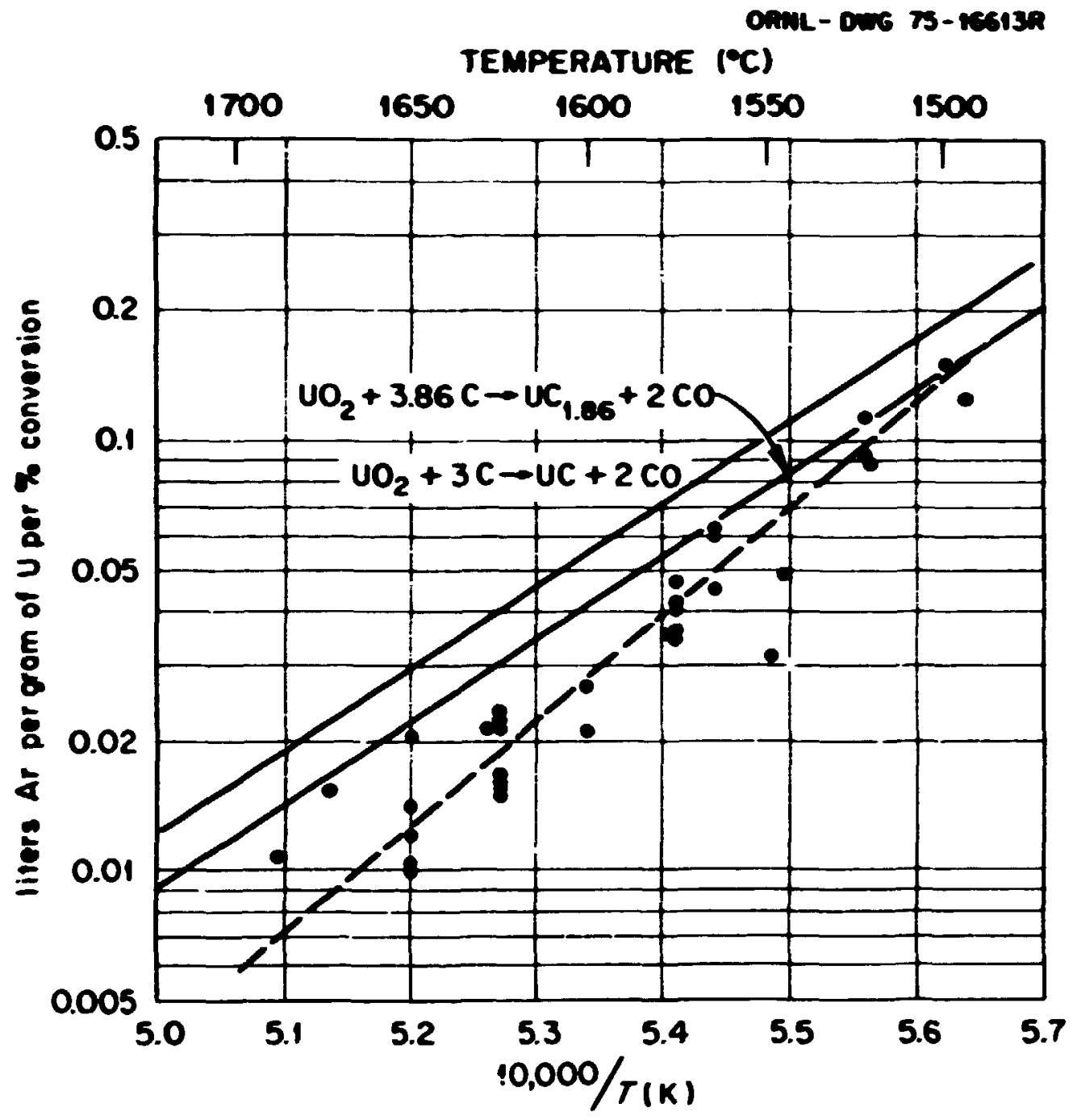

Fi2 26. Conversion Behavios of Weak-Acid Resin-Datived Fud.

show that as flow is decreased from 8.0 to 7.0 and $\mathbf{G . 0}$ liters;min, the temperature rises correspondingly if the bed is free fowing. An increase to 10.1 liters/min produces a corresponding temperalure drop. However. bed temperature behaves erratically in relation to both gas fow and the control measurement if particle sticking or ayomeration oxcurs and the bed is no longer free nowing. Considera'., variation in the convarsion level could be obtained with a specific temperalure and gas now if hed fluidization hehavior is not closely monitored.

Batch size and particle size have only a small. ii any. effect on the conversion level under these conditions ( Table 8). On the other hand, specific gaw flow rale has a large effect.

The strung dependence of perient conversion on gas fluw ; ig. 20) is in accordance with the model described by Lindemer 2 and Beatty ${ }^{3}$ in which an increase in argon now ratc would be expected lo increase the reation rate. If sufficient porosity is available so that diflusion is not the ratc limiting step in the carhon monoxide removal, the percent conversion can be predicted by using published values for the equilibrium partial pressure of carbon monoxide for the appropriale conversion reaction. However. Johnson ct al." found that increasing the gas now during the conversion process from 1 scim to 3 scfm acitually 


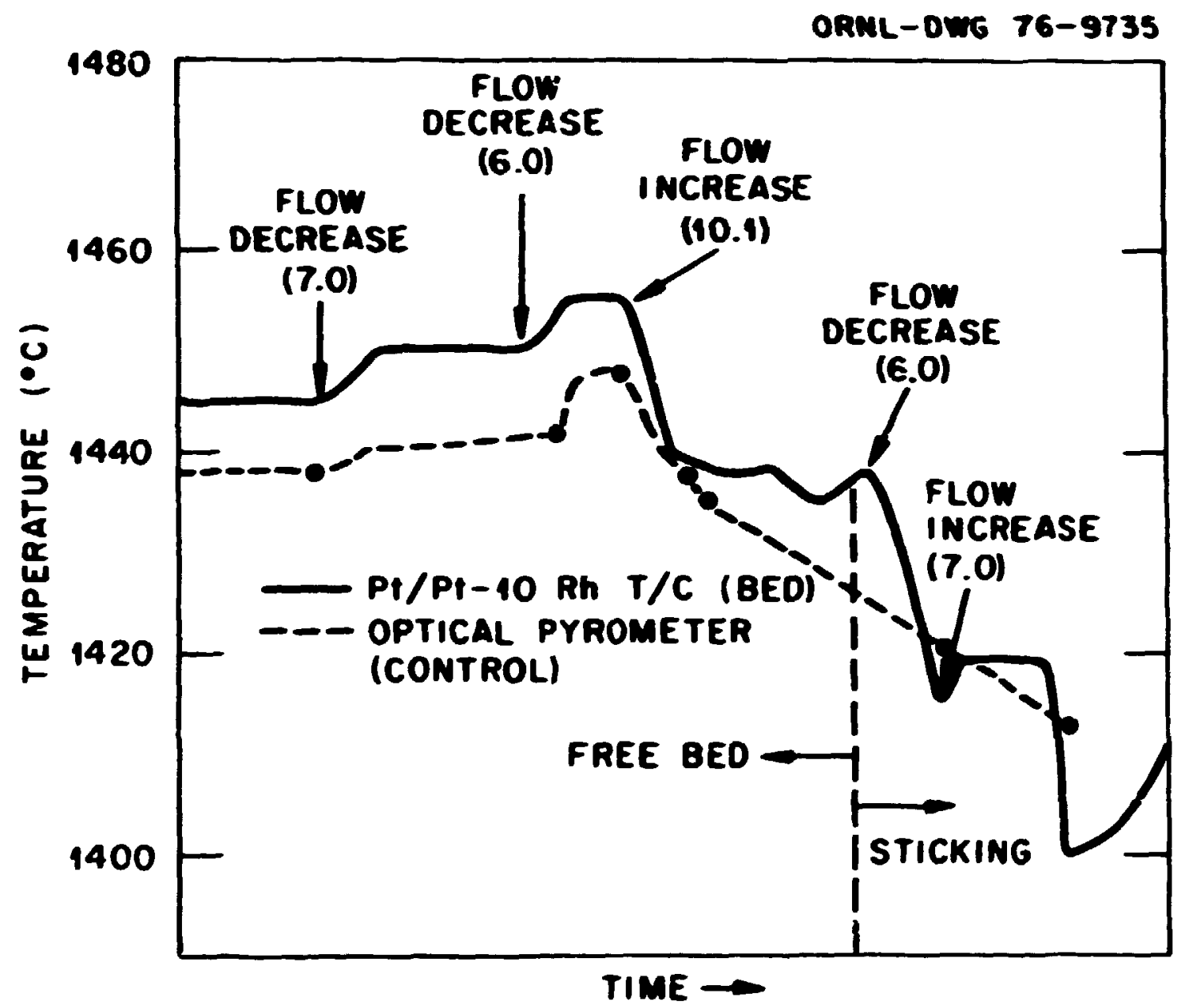

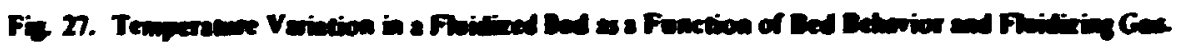

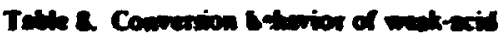
nimblesing five

\begin{tabular}{|c|c|c|c|c|}
\hline \multicolumn{2}{|c|}{ Particle sine } & \multirow{2}{*}{$\begin{array}{c}\text { Boteh } \\
\text { sine } \\
(\varepsilon)\end{array}$} & \multirow{2}{*}{$\begin{array}{l}\text { Total } \\
\text { es fow } \\
\text { (1/E U) }\end{array}$} & \multirow{2}{*}{$\begin{array}{c}\text { Conversion } \\
\text { levet } \\
\text { (\$) }\end{array}$} \\
\hline (mesh) & $\begin{array}{c}\text { Diameter } \\
\text { (mm) }\end{array}$ & & & \\
\hline $25-30$ & $590-710$ & 40 & 1.17 & 29.7 \\
\hline $35-40$ & $420-500$ & 40 & 1.17 & 35.6 \\
\hline $25-30$ & $590-710$ & 150 & 1.17 & 35.1 \\
\hline 3540 & $420-500$ & 150 & 1.17 & 35.0 \\
\hline $35 \times 40$ & 420-sor & 40 & 20 & 47.9 \\
\hline 35. 40 & $420-500$ & ISO & 2.1 & 53.4 \\
\hline
\end{tabular}

ADried. Inaded IRS - 72. 
decreased the cenversion ievel. This was attributed to a decrease in particte temperature as the gas flow was increased and more heat moved from the particles to the agon. It was also argued that this derease in partikle temperature would not be ctecitable on tixe exteriox of the rexition shamber. Using Lindenxi's model. Johnson. et al. ${ }^{8}$ iakulated a decrease of $100^{\circ} \mathrm{C}$ in the effective partikle temperature withuut a corresponding decrease in the nieasured wall temperature. Ant ixirease in the gas llow does producie a decrease in bed temperature (Fig. 27). However. the observation of this decrease is rapidly and u iformly followed by the iontrol py rometer observation through the outside of the fluidizing tube as long as the bed is nains fluidized. Wher the bed begins to agdumerate. and fluidistion conditions are uniertain. ihis ic: respondence is lost and the effect may be reversed to where a higher llow may yield a highter temperature, in accordance with the behavior observed by Juhnson et a. Juhnsori's experiments used a iunstant tluidiriag gas flow from rown temperature to $1800^{\circ} \mathrm{C}$. whereas the experinkents in this study used a decreasing gas flow as temperature was inteased. Pilloton states that the minimum fluidization gas flow is picportional to the reciprocal t the kinmatic viscosity of the tisidising gas. ${ }^{15}$ Althugh gas visiosities at high temperatures are not readily available. Nestor has derived an expression for their temperature dependenic." From :hese relationsnips Pilloton has shown that the tempeiature cixefficient of tixe minimum gas mass flow for fluidization shows a decrease of a factor of $25 / 1$ irom $25^{\circ} \mathrm{C} 101800^{\circ} \mathrm{C}$.

It is thus conceivable that the conditions observed by Johnson et al." with a constant fluidiving gas tl "w may have led to inatequate fluidizing conditions during carbonization for the lower gas llow employed. This may have resulted in the carbunized resin having different properties before and during cunversion. therefore the resin's behavior during the conversion provess would have been unpredictable.

\section{Produat Phase Evaluation}

Studies to determine the phase centent of converted material were done by varying the conversion remperalure and conversion atmosphert. The relative amount of the $U C_{1-x} O_{x}$ phase, as datermined semiguantitatively from $x$-ray powder camera films (Fig. 28 ) are shown in order of decreasing amount of IC,, $\mathrm{O}_{\mathbf{x}}$ (Table 9$)$.

The tun with argon +0.75 equilibrium $p_{\mathrm{CO}}$ hid no detectabie $\mathrm{UC}, \mathrm{C}_{\mathrm{x}}$ phase and showed unly $\mathrm{UO}_{2}$ and $\mathrm{UC}_{2}$. No other phases were observed. The runs at $1505^{\circ} \mathrm{C}$ and at $1625^{\circ} \mathrm{C}$ with $+\% \mathrm{H}_{2}$ addition had essentially the same content of $U C_{1}, O_{x}$ with tice balance $\mathrm{UO}_{2}$ and $\mathrm{UC}_{2}$. The $U \mathrm{C}_{1-\mathrm{x}} \mathrm{O}_{x}$ was in i instances a minor phase.

It apposis that lower teinperatures with corresponding long:t times result in iess of the $\mathrm{UC}_{1}, \mathrm{O}_{x}$ ph ase being present in the kernels. Also. the use of 0.75 equilibrum Pco to increase the time at a given temperaluse fior an equivalent conversion level by a iactor of 4 essentially climinates the $\mathrm{UC}_{1}, \mathrm{O}_{\mathrm{x}}$ phase from the converted kerneis. The use of a $\mathrm{fr}^{\mathrm{i}} \mathrm{H}_{2}$ addition decreuses the amount of $\mathrm{UC}_{1}, \mathrm{O}$, approximately as inkich as docs lowering the inversion temperature by $120^{\circ} \mathrm{C}$. The exposure of the carbe nized resin to air before conversion does not appreciably affect the amount of this phase. As lite for: converted argon run is comparable to conditions normall! used in fuei fabrication. partially converted weak-acid resin fuels nominally contain $1 \mathrm{O}_{2}, \mathrm{UC}_{2}$. and minor amounts of $U \mathrm{C}_{1}, \mathrm{O}_{\mathrm{x}}$.

The decreasing arnounts of $\mathrm{UiC}, \mathrm{O}_{\mathrm{x}}$ as temperature is decteased indicates that the $\mathrm{UO}_{2} \rightarrow \mathrm{UC}, . \mathrm{O}_{\mathrm{s}}$ reaction is inore favorable kinetically as temperalute is increased relative to the $1 / O_{2} \rightarrow\left(I C_{2}\right.$ innversion).

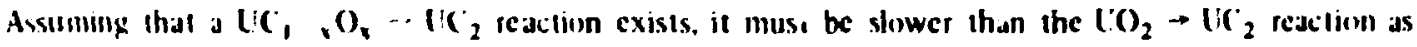
longer limes show decreased levels of $\mathrm{U}\left(\mathrm{C}_{1}, \mathrm{O}, \mathrm{K}\right.$. Ketatding conversion by addition of carbon monoxide allows I closer approach (o cepuilihrium for the solid state reactions. The ddition of hydrogen probably provides a more efficient transport mechanism for th: $\mathrm{LiC}_{1}, \mathrm{O}_{\mathrm{x}} \rightarrow \mathrm{UC}_{2} \mathrm{re} \mathrm{ection.}^{\mathrm{I}}$

A wide range of linal kerne! composilions and densilies can be fahricaled depending apon the specilic cartwomizalion rale and the perient conversion (Tahle 10). 


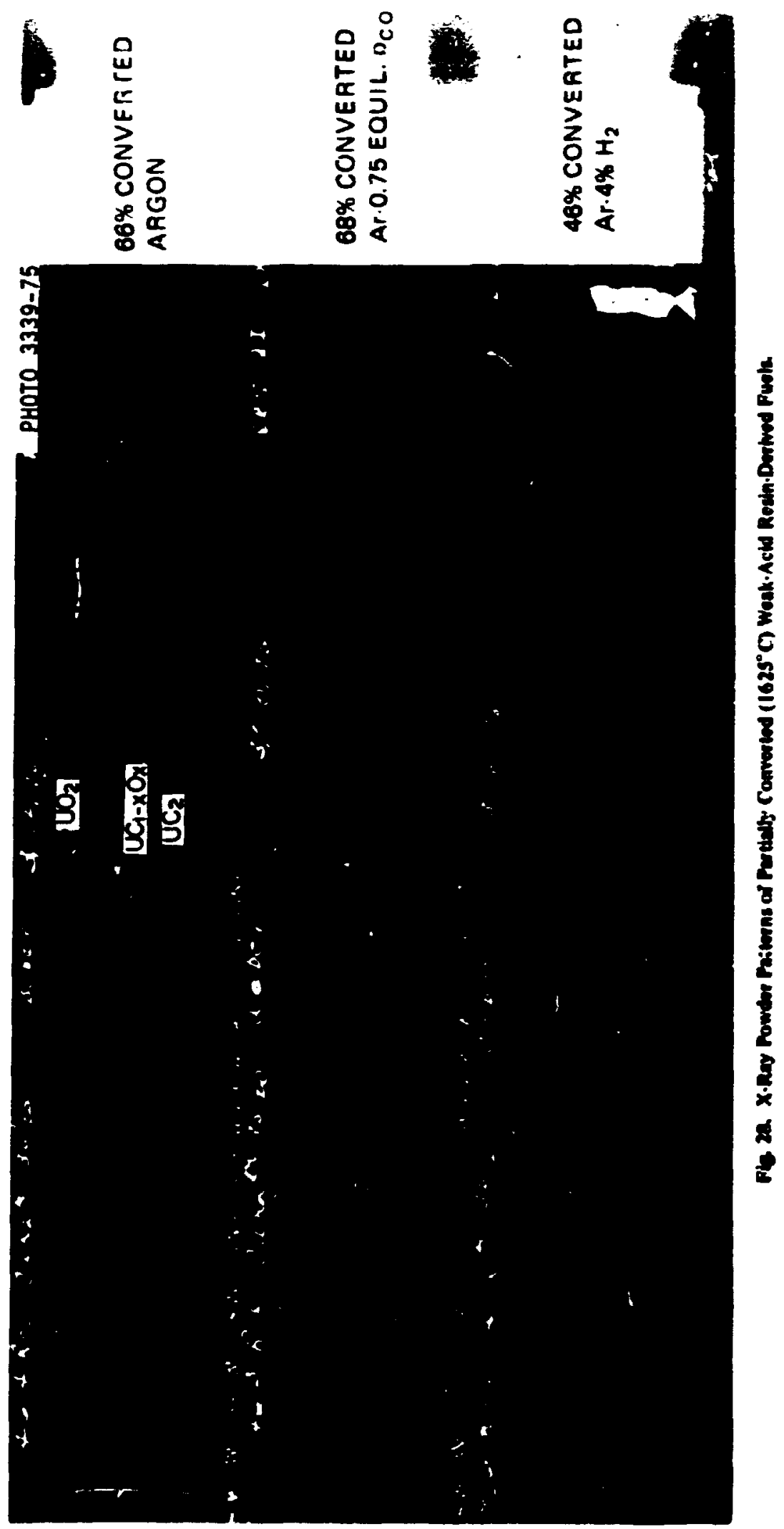




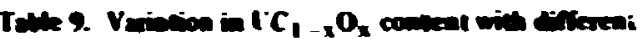

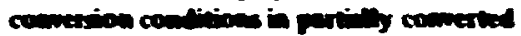

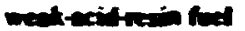

\begin{tabular}{|c|c|c|c|}
\hline $\begin{array}{l}\text { Temperature } \\
\text { PO }\end{array}$ & Compersion comdinions & $\begin{array}{l}\text { Cumersion } \\
\text { (f) }\end{array}$ & Rebive \\
\hline 1625 & Arear & 66 & Moting \\
\hline 1623 & $\begin{array}{l}\text { Arpon exposed to ai before } \\
\text { conversiog }\end{array}$ & 57 & Motion \\
\hline 1625 & Arow $-49 \mathrm{H}_{2}$ & 37 & $\begin{array}{l}\text { Weat } \\
\text { Weat }\end{array}$ \\
\hline 1628 & Anpon + 0.75 equitions PC & 6 & Absem \\
\hline
\end{tabular}

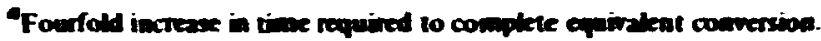

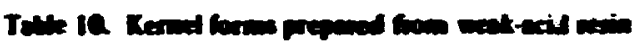
for intivion

\begin{tabular}{|c|c|c|c|c|}
\hline Ketret compositione & $\begin{array}{c}\text { Comersion } \\
\text { (17) }\end{array}$ & $\begin{array}{c}\text { Carbomization } \\
\text { nate } \\
1^{\circ} \mathrm{C} / \mathrm{mom} . \\
200-500^{\circ} \mathrm{O}\end{array}$ & 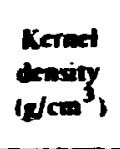 & Imdiation \\
\hline$l \cdot C_{5.5}-0_{2.0}$ & 0 & 2 & 3.22 & of - $2^{\infty}$ \\
\hline $\mathrm{C} \cdot \mathrm{C}_{4.6}=\mathrm{O}_{2.0}$ & $\mathbf{0}$ & 40 & 3.66 & $\begin{array}{c}\text { HRE-9c }-10 \\
\text { OF-2 }\end{array}$ \\
\hline $\mathrm{C} \cdot \mathrm{C}_{5.5}-\mathrm{O}_{1.7}$ & 15 & 2 & 3.12 & or 2 \\
\hline $\mathrm{U} \cdot \mathrm{C}_{4.4} \cdot \mathrm{O}_{1.7}$ & 15 & 6 & 3.17 & $\begin{array}{c}\text { HRE - } 7 \text { 8. } \\
10\end{array}$ \\
\hline$U \cdot C_{5.1} \cdot 0_{1.5^{\circ}}$ & 25 & 2 & 3.17 & or -2 \\
\hline$t \cdot C_{1.6} \cdot 0_{1.0^{\circ}}$ & 50 & 2 & 3.11 & $\begin{array}{l}\text { HRE - } 4 . \\
\text { OF- } 2\end{array}$ \\
\hline$c \cdot c_{4.1} \cdot 0_{0.5}$ & 75 & 2 & 3.03 & $\begin{array}{l}\text { HRE - } 9 .-10 . \\
\text { OH-2 }\end{array}$ \\
\hline $\mathrm{Li} \cdot \mathrm{C}_{3.7^{\circ}}$ & 100 & 2 & 3.01 & $\begin{array}{c}\text { HRB } 9.10 \\
\text { of }-2\end{array}$ \\
\hline$U=C_{2.6}^{\circ}$ & 100 & 6 & 5.28 & $\begin{array}{c}\text { HRB } 7.8 . \\
-10.0 \% 2\end{array}$ \\
\hline$U \cdot C_{5.3} \cdot 0_{1.7^{d}}^{d}$ & is & 2 & 2.41 & HRB-W \\
\hline$v \cdot c_{4.8} \cdot 0_{1.0}$ & so & 2 & 2.45 & HRa-II \\
\hline$i \cdot C_{4.5} \cdot 0_{0.6}^{d}$ & 70 & 2 & 2.53 & HRB II \\
\hline$U \cdot \mathrm{r}_{5.2} \cdot \mathrm{O}_{1 . t^{d}}$ & 30 & 2 & 2.42 & HRE II \\
\hline
\end{tabular}


Urmien Loss Derims Connesien

Utanium loss during conversion was determined by use of a water-coulea furnace probe to be $38 \mathrm{me}$ for 150 \& of WAR 108 \& Ul shape separated rejected kemels 737 comerted at 1650 to i $800^{\circ} \mathrm{C}$. Alpha counting of the probe yietued 348 dis/min. After a $98 \%$ conversion at $1775^{\circ} \mathrm{C}$ of a $150 \mathrm{~g}$ bakch of spherical particles. Ilpha cunnting of the probe showed 787 dsimin Apin the particles impinged directly on the probe. As these iwo runs represented combinaticins of worst-iase siuations including rejaited particle shapes. direct partick impingement. and full conversion at hit emperatures. the values of uranium loos duriag normal cunversion cunditions are anticipated to be sorme what less than 0.035\%.

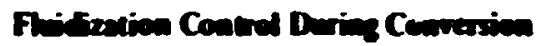

The agdometation cendency of the microspheres at high temperature is sensitive to the amount of exiess arbun intained (Firs. 8. 12, and 13) as a funition of arbonization rate. The density of fully reduced particles varies from $<3.0 \mathrm{~g} / \mathrm{cm}^{3}$ for two excess moles of $C: U C_{2} 105.28 \mathrm{~g} / \mathrm{cm}^{3}$ for one mole of excess C: UC: (Table 10). Fully reduced materials of lower C: $U$ have not been prepared. but densities above $6.0 \mathrm{~g}^{\prime} \mathrm{cm}^{3}$ would be expected. As indicated carlier, nunagdomerating microspheres with $C: U>6$ as carbonized can be iully reduced with excelkent control. However. Iwo operational diffuculties are excountered in rechuing particles having a $C: U$ much below 6 as carbunized: the open porosity is reduced s) that the reduction rate pluts (Fig 4) du not apply, and the particles agdometate so that such a parially reduced batch cannot be assuicd to have equal particle-to-particle conversion.

A study was done to establish a sricting pancere which could be used for different batch sizes. thbe sives. cone andes. cone designs, and frits. The problem aries in the different sticking behavior vberved for the same sine batch in different tube sizes and cone andes for different density particles. or for different sise batches in the same rube. Wormalizing the gas fux with tube area yields only a partial solution. As the agdimerating tendency is resisted by the kinetic energy of the particlex, a time-averaged minimum mean particle kinetix energy might well be a useful prameter. However, this value is difficult to evaluate for different bed configarations and fuidizing conditions for all positions un the bed.

Comparative agjomeration or stickine during conversion of weak-acid resin-derived fuel was measured with an injectur pressure gage. The comersion time duing which different adomeration behavior was ubserved is a function of ga flux with respect to particle surface area (Fig 29). Sticking behaviox is strongly gas-flow dependent. A cunversion level of $50 \%$ is free from sticking at the highest gas flow. whike any conversion level in excess of 15\% exhibits some sticking betavior at the lowest gas flow sudied. Additionally, in all of the runs studied. stivking appeared to follow a regalar pattern of gadually deteriorating bed fuidization with time at conversion temperature.

Batches which have apomerated 2 . often refluidized by lowering the temperature approximatelv $100^{\circ} \mathrm{C}$ and ther: retuming tu conversion temperature. Aso. deireasing the conversion temperature makes it possible to complete conversion runs undet conditions which would otherwixe yield unacceptable aglomeration. Similarly, sticking ochavior is strongly temperature dependent. 17

In another approach used to aroid the bed aglomeration problem. a porous buffer coating can be applied to the particles after carbonization. This allows the bed to be fluidized at $1800^{\circ} \mathrm{C}$ for any length of lime withoul slikking. while allowing carbon monoxide to be removed rapidy through the buffer. Further. application of the buffer immediately following carbonization fixes the volume inside the coating at the volume of the kernet. The buffer does not change dimensions significantly while the fuel is being converted (1) carbide. In some experiments this resulted in a void between the kernet and buffer, while in other experiments the buffer prevented shrinkage of the kernel during reduction. In either case the free volume 


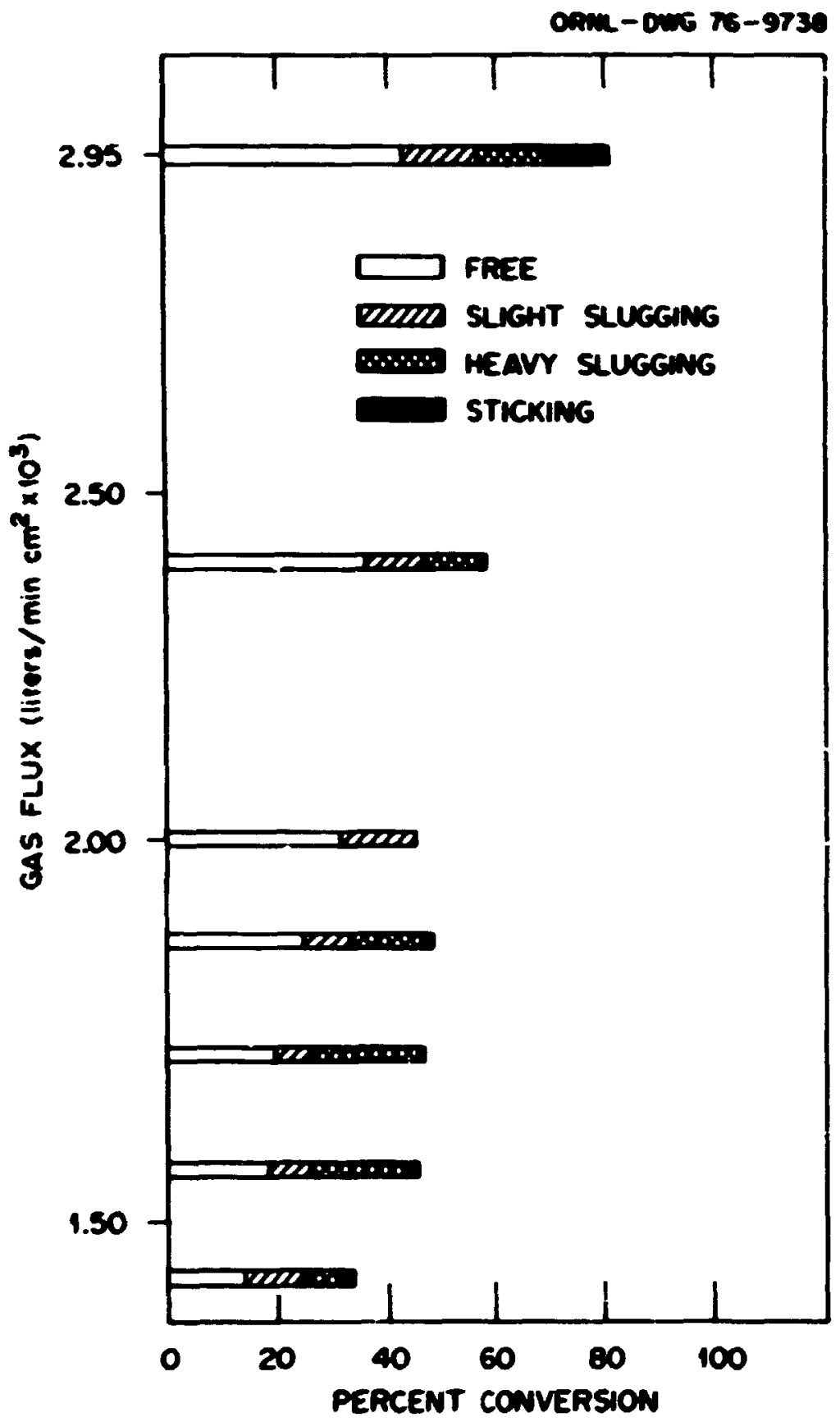

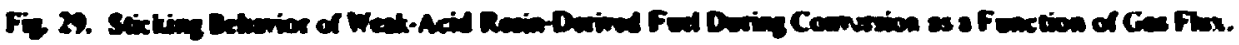

assucialed with the kernel. exclusive of the buffer, is a direct function of lemel volume. This should $\mathrm{h}$. advantageous in particle design where a range of kernel diameters and buffer thicknesses must $\mathrm{h}$. aciommodated. When kemel shrinksg is prevented, carbothermic reduction of the fuel can be cinupliolial in about $10 \mathrm{~min}$ at $1800^{\circ} \mathrm{C}$. 


\section{Reactivity with Ais}

Onepan batches of resin carbuniced 10600 or $1200^{\circ} \mathrm{C}$ and converted at $1600^{\circ} \mathrm{C}$ were exposed to rown atmunphere to delermune the reatinity with air. Afker $75 \mathrm{hr}$. the meight increases of the partixles

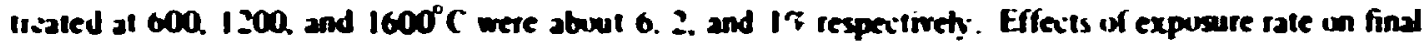
weiph pin were insignificant though weight grins during the first hour were aburt twice as great in the upen beakers as in the uncapped butcles During the first $10 \mathrm{~min}$. the partictes carbonized $10600^{\circ} \mathrm{C}$ initeased in weipht nearty $3 r$ in the buttiks and nearly $5 x$ in the beakers. Weights of all batches increased uniformb throuph a 27-tw mexurement. then Muituated over a small range with no apporent pattern. This may have been due to variations in room humidity: but bumidity was not monisored in this experiment.

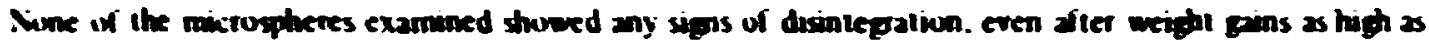
6. F. Fen the mest reative particles. thuse haled to only 600 C. remained miact and did not burn when expased to roum atmusphere for bag times. The partiktes carbunived at rither $600^{\circ} \mathrm{C}$ or at $1200 \mathrm{C}$ were expused to air ion five dys. then reteaked to $1200^{\circ} \mathrm{C}$. The microspheres originaly heated to only $600^{-} \mathrm{C}$

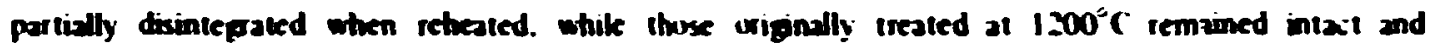

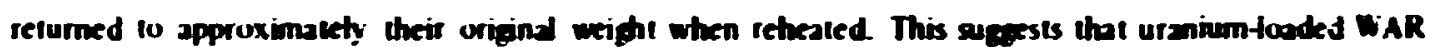
treated at $1200^{\circ} \mathrm{C}$ or higher temperature may be handed in an if necessang. but thete is one resiri, iun: The posticies du initially react rapidly enuogh to produce noticeavie heat. In small bouthes. they simply get warm but do not bum: in lare balches it would be necessary to cool the macrial wo aroid a fire hazad.

Materials carbunixed through the initial heating rate range, fully carbonized. and fully reduced to dixarbide teaty became less reacive with the room atmosphere with furthet themal ueatment (Fiz- 30 .

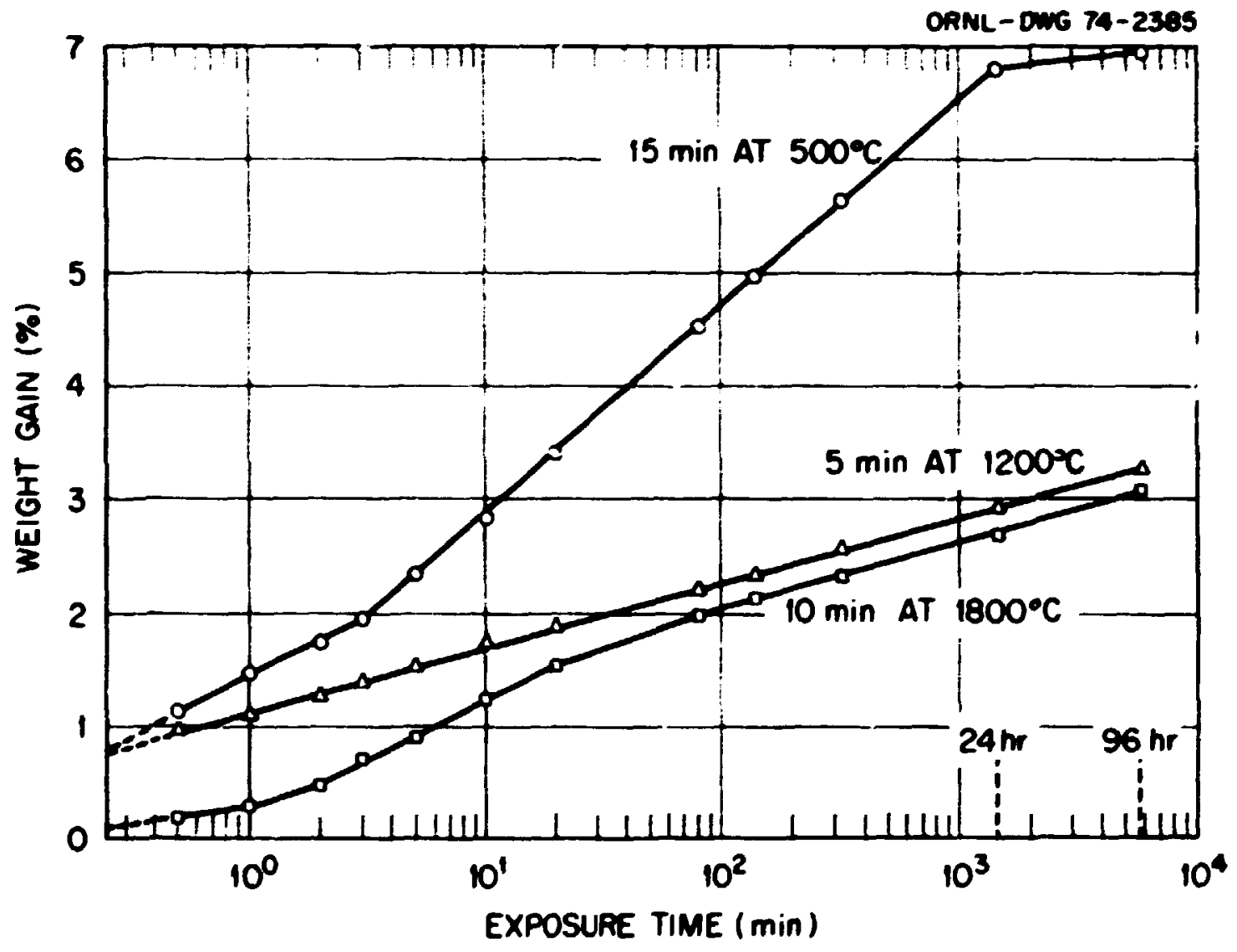

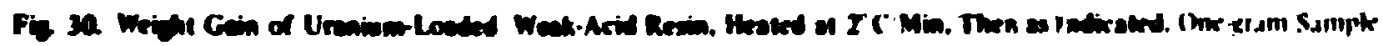
Fxponed in Loboratony Aw as Sinde Layer of Micropphers. 


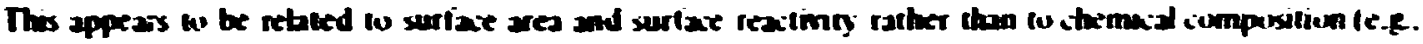

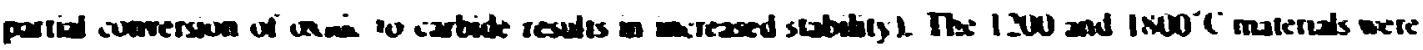

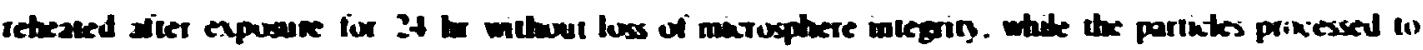

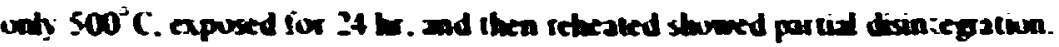

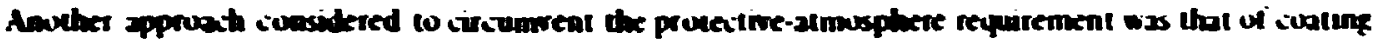

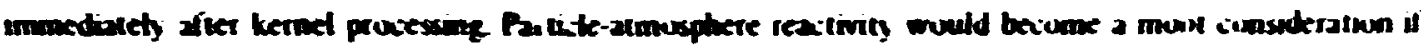

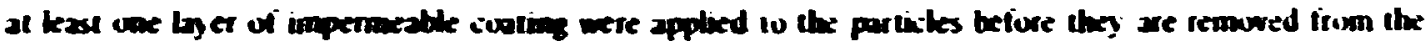

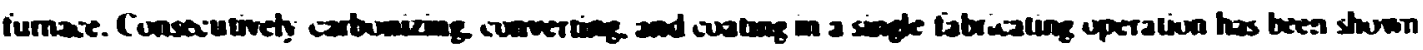

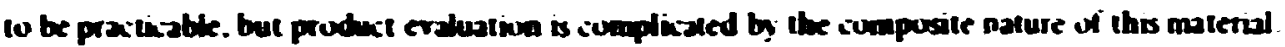

\section{concusians}

1. Feak-aid wa-exctange resios provide a versatile substance ior iabrication of uranium-iontaming HTGR finel kernets.

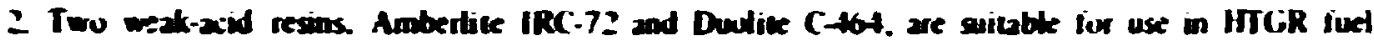
iabrivatied.

3. Kernel carbon coavent and bulk physizd properties ctosely reflect be TCiA betavior and anc sensitive to hating race chrough a marrow critical temperature range from shurt 350 to $\$ 10$ ( during the irbunkation provess.

4. The carbonization process ian be cptimiced for both property controd and provess llow with a sabunuation rake of appoximately $20 \mathrm{C}$ min through the critival range and the maximum praitiable rate wetside this range.

5. The cometsion or arbothermin reduition of the $\mathrm{CO}_{2}$ present after arbunivation ian be effected in a contrulled mannet in a fuidized bed at tempetatures from 1500 to $1750^{\circ} \mathrm{C}$.

b. The conversion rate is controlled by the rate of carbun munoxide remowal and is prediciable by thermudy namia cakubtions based on cemperature and specific inest ges sweep rate.

7. Major phases present in partially converted material are $\mathrm{UO}_{2}$ and $\mathrm{UC}_{2}$. The amuunt of a minix phase. $\mathrm{UC}, \mathrm{z}, \mathrm{O}$. depends on cunversson cundetions.

8. A tendency of the partickes to agdumetate during conrersion can be cifecimely countered by contrulling the carbonitation rate to maximice carbon content. lowering temperature. vriteasing gas flow. or by buffer cootmg before conversion.

9. Duolite C-464 is superior to Amberlite IRC:-72 in its ressuance to sintering and atomeration and is hence easier to control during conversion.

10. Uianium volatiliation during proxessing is nefigible except with extremeiy rapid arbonization.

II. Carbonized and/or converted kernets are sufficiently reactive to require a protective atmosphere and may iprite if exposed to air in bed depits geater than a few par icke dameters.

\section{ACKNOWLEDCMENTS}

The authors would like to express their appreciation to the pioneering work dune in the development if uranium-loaded meak-acid resin fuel by J. M. Leitnaker. C. B. Pollock. J. L. Sxoll. and M. D. Silverman. Wc wah if express our appreciation to C. Hamby. Jr., B. R. Chikeal, and W. Smith who prepared the umples, B. R. Cavin for the $x$-ray analyses, W. R. I aing for ine analy tical chemistry. and W. J. Mason for rudisgraphy of the samples. The uranium-loeded resin parlicles were supplied by P. A. Haos and J. Shaffer "I) the (heme-al Technotugy Division. We wish to acknowtedge T. B. Lindemer for his many helpful 
sugasinns and W. P. Laiherly. W ;. Lekey. and J. A. Cappenter. Jr. For their assistane in planning the tsa prigam. The manusinpt was edited by (: w. Gnifith and prepared for reproduction by the Cimpissinm Seitun. Teihnoid Publiatiuns Deportment.

\section{REFERENCES}

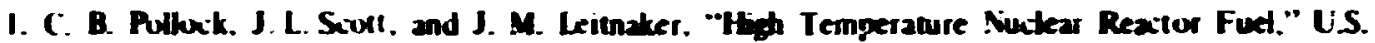
Patent Nu. 3,856.622. Dex. 24. 1974.

2. P. A. Haxs. "Looding a Cativen-Exctangs Resin with Uranyl luns." U.S. Patent No. 3.800.023. March 36. 1474 .

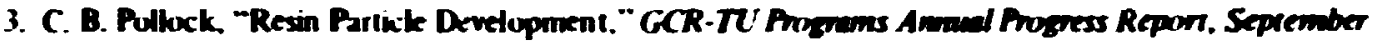
30. 1971. ORNL 4760 . pp. 46100.

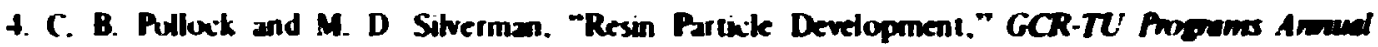
Presers Repurt. Dec. 31, 1972. ORNL-4411. Pp. 9095.

5. R L Beatly. "Carbunizaikn and Cuating of Fueled Resin Miktospheres." presented at 7oth Annual Meeting of Amer. (eram. Sox... April 29. 1974. Chizagu. III. Abstrait in Am Cerm Six. Bull. 534):363 (1474).

6. M. D. Sitverman and C. B. Pollock. "Resin Fuel Partikles for High Temperalrie Gas-Cooled Reaitiors." I th Biennial Cont. Carbun. Gatlinburg Tem.. June 4 8. 1973. Conf-730601. Pp. 245-46.

7. R. L Beatty and E. L. Long. Jr.. "Preparation and Performanice os c wated Particke viuclear Fuels

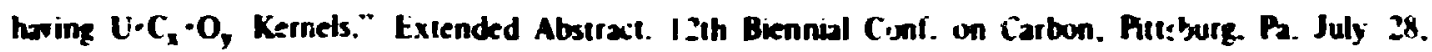
1475.

8. D. R. Johnsun. W. J. Lakey. and J. D. Sease, "The Effects of Processing Variables on HTGR Fuel Kernels Fabrialed from Uranium-Loaded Gation Ex:hange Resin." ORNLiTM 4989 (Aug. 1975).

9. J. L. Siut1. J. A. Conlin. J. H. Coubs. W. P. Eatherly. F. J. Homan. and E. L. Long. J. "Performanue of Candidate HTGR Fuels in Fuel Rod Iradiations in HFIR." ORNL TM4554 (Oct. 1974).

10. F. S. Homan. J. H. Cuobs. R. L. Hamner. J. A. Condin. B. H Monigomery. E. L. Long. Jr. and J. L. Scull. - Irradiation Performance of HTCR. Fuel Rous in HFIR Experiment HRB-3 and ETR Experiment P I3 N.ORNL TM-4526 (0.1. 1974).

II. Amberlite IRC.72, Rohm and Haas Information Bulketin.

12. T. B. Lindemer. "Rate Controlling Factors in the Carborhermic Synthesis of Advanced Fuets." Nucl Apol. and Trch.9. 711 - 1561970).

13. R. Bacon. p. 13 in Chemissy and Physics of Corbon. vol. 9. P. L Walker and P. A. Thrower. ed. Dekker. New York. 1973.

14. B. D. Cullity, Hkmente of X-Rey Liffraction, p. 99. Addism-Wedey. Reading. Mass., 1956.

15. R. L. Plloton. "Gas Flov: Cakulations for Fluidized Bed Coating of Nuclear Fuet Particles." ORNL-3639 (June 1964).

16. C. W. Nestor. ONNL Mathematixs Division, unpublished data cited in ORNL-3639 (June 1964). p. 16.

17. R. D. Langeley. General A.tomic. LaJnlla. Calif.. personai communication. 